\title{
28. SECONDARY MINERALS IN OCEANIC BASALT, WITH SPECIAL REFERENCE TO LEG 34, DEEP SEA DRILLING PROJECT
}

\author{
Manuel N. Bass, Department of Terrestrial Magnetism, Carnegie Institution of Washington, Washington, D.C.
}

\begin{abstract}
Secondary minerals in oceanic crustal basalts can be discussed in terms of four sets of processes: (1) late magmatic-deuteric alteration; (2) seawater alteration (preburial); (3) nonoxidative diagenesis (postburial, limited oxidation); and (4) oxidative diagenesis (postburial, intense oxidation).

Late magmatic biotite, oxidized titanomagnetite with ilmenite lamellae, and iddingsite are succeeded by deuteric chlorite (paperthin veins rich in chlorite), minor talc, and possibly quench smectite. The cold, glassy surfaces of the flows and pillows are altered to orange and red palagonite while in contact with oxygenated bottom water. The interstitial glass below the surface is altered first to golden yellow palagonite; ultimately it may yield poorly crystallized smectite ("fibropalagonite"). If oxygen reaches it, the color turns brown. The interstitial glass is $\mathrm{Fe}-$ and $\mathrm{H}_{2} \mathrm{O}$ - richer than surficial sideromelane and alters more rapidly. Olivine near, but below the surface, is altered initially to smectite; when oxygen reaches it the remaining olivine is altered to earthy $\mathrm{Fe}$-oxide.

Seawater alteration in the strict sense is terminated by deposition of a sedimentary blanket. In deep areas of pelagic sedimentation the sediments are almost wholly oxidized and poor in organic matter when deposited; they thus serve to retard the supply of oxygen from bottom waters only as a diffusion membrane and not as a chemical sink. Therefore, with low rates of sedimentation of porous pelagic sediments, we expect the underlying basalts ultimately to be oxidized. The advent of abundant oxygen terminates the stage of nonoxidative diagenesis, which is characterized by such low oxidation rates that the resulting $\mathrm{Fe}^{+3}$ can be incorporated in the green to blue-green smectite without forming independent ferric $\mathrm{Fe}$ compounds.

The nonoxidatively altered rocks are gray and appear deceptively unaltered at first sight. The least-fractured basalts in the interiors of thick cooling units are almost wholly unoxidized (fewer than $10 \%$ of the $\mathrm{Fe}$ atoms are $\mathrm{Fe}^{+3}$ ), but most show significant oxidation. The main nonoxidative changes in them among primary phases are replacement of olivine and interstitial glass by relatively wellcrystallized smectite. The olivine pseudomorphs may contain minor talc, traces of mica, and minor to abundant carbonate. Clinopyroxene, plagioclase, and titanomagnetite are unaltered.

Nonoxidative diagenetic veins are mainly saponitic smectite, magnesian calcite, aragonite, marcasite, and pyrite, with lesser celadonite, chlorite, talc, and random-mixed-layer chlorite-smectite and mica-smectite. The high $\mathrm{Fe}^{+3} / \mathrm{Fe}^{+2}$ of the smectite reflects the fact that significant oxidation does occur during "nonoxidative" diagenesis. Nonetheless, sulfides did form, utilizing sulfur from an unknown source, mobilized by unknown agents. The susceptibility of Fe to oxidation must exceed that of sulfur. If marcasite can form in alkaline solutions at $4^{\circ} \mathrm{C}$, its association with smectite will pose no problem. Diagenetic chlorite apparently increased toward the later stages of deposition of the smectite veins. The aragonite shows no sign of solution, etching, or inversion, and thus probably formed after the associated magnesian calcite. The smectite is almost silica saturated and prevents significant buildup of $\mathrm{Si}$ activity in solutions. Thus, silica-rich phases like talc and celadonite are not abundant, and quartz is rare. Celadonite is also limited by availability of $\mathrm{K}$; nonetheless, in the few celadonite-rich veins, $\mathrm{K}$ (and $\mathrm{Si}$ and $\mathrm{Fe}^{+3}$ ) must have been abundant.

A plot of the limited chemical analyses of smectite and celadonite from oceanic basalts in a modified AKF diagram indicates that the
\end{abstract}


observed nonoxidative diagenetic phyllosilicate assemblages do not violate phase rule requirements and thus approximate stable or metastable equilibrium assemblages. The celadonite plus goethite associations may similarly approximate equilibrium assemblages under oxidative conditions. Phillipsite is rare in nonoxidatively altered basalts, but does occur. Its formation may depend on local sources of abundant $\mathrm{Si}$, such as the glass walls of vesicles, since phillipsite appears to compete poorly for soluble $\mathrm{Si}$ with the nonoxidative phyllosilicates. Todorokite and rare nonoxidative birnessite are characterized by unusually good crystallinity.

The advent of oxidative diagenetic conditions is marked by sharp, diffusion-controlled fronts separating the gray, nonoxidatively altered rocks from red or brown, oxidatively altered ones. The visible change rests on the precipitation of substances rich in ferric $\mathrm{Fe}$, either amorphous or crystalline, due both to an increase in the amount of available $\mathrm{Fe}^{+3}$ and to the cessation of crystallization of all phyllosilicates except celadonite, hence a reduction in the number of phases which consume $\mathrm{Fe}^{+3}$. Remnant olivine is replaced by earthy $\mathrm{Fe}$ oxides, like those produced during seawater alteration. Titanomagnetite is oxidized through titaniferous maghemomagnetites toward maghemite (see Ade-Hall et al., Rock Magnetism, this volume). The outer Fe-rich rims of zoned clinopyroxenes may be altered, but plagioclase remains fresh.

Nonoxidative smectite, and possibly chlorite, is oxidized to a colorless smectite in which charge balance due to oxidation of $\mathrm{Fe}^{+2}$ is restored by expulsion of $\mathrm{Fe}^{+3}$ as dusty red pigments. Chlorite may be replaced by goethite on a relatively coarse, even macroscopic scale. Ultimately, smectite and chlorite may be destroyed. Sulfides are oxidized and the resulting sulfate lost, so that oxidatively altered rocks are notably low in $\mathrm{S}$ content. The sulfuric acid generated by the oxidation helps the dissemination of Fe stains around the former sulfides until the acid is neutralized. Relatively $\mathrm{Mg}$-poor calcite forms directly from solution and by inversion of aragonite. The calcite formed by inversion of aragonite may be biaxial. Phillipsite is abundant in oxidatively altered rocks at and near the surfaces of cooling units, not because it requires oxidative conditions to form, but because competing silicates are minor or absent, and the glassy rinds provide a ready source of $\mathrm{Si}$. Celadonite competes for $\mathrm{Si}$, but forms only if $\mathrm{K}$ and soluble $\mathrm{Fe}^{+3}$ are also available. $\mathrm{Fe}$ and $\mathrm{Mn}$ oxides formed oxidatively in near-surface parts of cooling units are poorly crystallized or amorphous. In the interiors they form much more slowly and are much better crystallized. Locally, hematite forms, either directly or by aging of goethite. Todorokite is destroyed unless armored by birnessite derived from it.

The calcite-aragonite relations are complex. It is unlikely that ikaite $\left(\mathrm{CaCO}_{3} \cdot 6 \mathrm{H}_{2} \mathrm{O}\right)$ is a precursor to either, but the monohydrate $\left(\mathrm{CaCO}_{3} \cdot \mathrm{H}_{2} \mathrm{O}\right)$ cannot be excluded as a precursor to aragonite. A more direct explanation for aragonite, however, is metastable crystallization in fluids so high in $\mathrm{Mg} / \mathrm{Ca}$ that calcite nucleation is excluded. A simple rationale for many observations is that early, nonoxidative saponitic smectite keeps $\mathrm{Mg} / \mathrm{Ca}$ of pore fluids low enough to allow nucleation and growth of magnesian calcite. Applying Katz's (1973) partition coefficient, extrapolated to $4^{\circ} \mathrm{C}$, to the writer's magnesian calcite compositions, it is inferred that they crystallized from solutions in which $\mathrm{Mg} / \mathrm{Ca}$ varied from 0.6 to 2.1. When smectite crystallization ceased or slowed, $\mathrm{Mg} / \mathrm{Ca}$ in the pore fluid rose and the calcite became more magnesian until the $\mathrm{MgCO}_{3}$ content reached about 10 mole $\%(\mathrm{Mg} / \mathrm{Ca}$ in fluid $=2.9)$ and calcite crystallization ceased. Then, or slightly later, aragonite began crystallizing, probably contemporaneously with late Mg-rich smectite and diagenetic chlorite. Oxidative conditions record the arrival, not only of oxygen, but probably also of fluids of low $\mathrm{Mg} / \mathrm{Ca}$, like the interstitial fluids of the overlying sediments. Under those conditions, relatively $\mathrm{Mg}$-poor calcite began crystallizing and aragonite was inverted to calcite. Magnesian calcites adjusted toward $\mathrm{Mg}$ poorer compositions, aided by the carbonic acid generated concurrently with oxidation of ferrous $\mathrm{Fe}$ and manganous $\mathrm{Mn}$ in the calcite lattices. Peculiarities of carbonate distribution are discussed in the light of this suggested paragenesis, but severe problems remain. 


\section{INTRODUCTION}

Shipboard petrography and subsequent microscopic and X-ray analysis of basalts recovered during Leg 34 confirm and extend certain observations and inferences regarding secondary alteration in submarine basalts drawn from a study of those cored during Leg 17 (Bass et al., 1973a, b). While the results are still preliminary and incomplete, they are sufficiently consistent to warrant tentative conclusions and a working hypothesis based on them. In the interest of brevity, this discussion will be presented in a posited style, without belaboring the uncertainties involved. Those uncertainties, the presence of which is acknowledged and emphasized, will fade only in the face of improved future data.

In this paper I discuss four groups of secondary minerals in the chronologic order of their formation: deuteric minerals; those formed in contact with oxygenated bottom waters prior to burial; diagenetic (i.e., postburial) minerals formed under nonoxidative conditions; and diagenetic minerals formed under oxidative conditions. As will become apparent, there is some overlap between the last three groups in that some minerals cannot be assigned with certainty to one rather than another.

The data are tabulated in Tables 1 through 4 and are graphically illustrated in Figures 1 through 4. Compositions of olivine and magnesian calcite are in mole \%, and X-ray diffraction peaks of unknowns are identified by their $2 \theta$ angles relative to $\mathrm{Cu} \mathrm{K} \alpha$ radiation. The bases for identifying the minerals and estimating the compositions of magnesian calcites are the same as those discussed in Bass et al. (1973a, p. 430-434). Olivine compositions were estimated by the X-ray method of Murata et al. (1965) which employs an LiF internal standard. Repeat analyses indicate a reproducibility of \pm 1 mole $\%$ Fo $( \pm 0.5$ mole $\%$ in cases of well-crystallized olivine with a narrow compositional range).

The various mineral groups are not equally developed in all rocks. Deuteric minerals, for instance, are identified only in the coarser grained interior parts of rela- tively thick, massive flows or sills. Palagonite, a seawater alteration product, is found only in glassy marginal parts of pillows and flows. In this regard, it is noted that all rocks cored in Hole 320B appear to be from pillows or thin cooling units. Those cored in Hole 319 are essentially holocrystalline, but represent thin, relatively rapidly cooled flows or sills, only slightly thicker and more slllowly cooled than those encountered in Hole 320B. Only among the rocks cored in Hole 319A and at Site 321 do we encounter, in addition to minor, finer grained, chilled facies, some coarser grained, more slowly cooled facies in which circumstances and slower cooling rates favored deuteric effects and the development of late, interstitial liquids that gave rise to mineral phases and glass especially susceptible to diagenetic alteration.

Except for phillipsite, no zeolites were identified in the basalts, so zeolite-facies metamorphism or diagenesis, such as that found in the crystalline rocks from Hole 165A (Bass et al., 1973a, b), did not occur. Instead, all alteration seems to have occurred in the presence of such high activities of various carbonate ion species that the assemblage calcite-smectite dominated (Zen, 1961), as in the Leg 17 rocks and those from virtually all other DSDP legs. Through Leg 34, therefore, penetration of up to 80 meters below acoustic basement has failed to retrieve the secondary zeolite-facies vein assemblages (dominantly laumontite) and other higher grade assemblages so commonly recovered by dredging submarine scarps and which form the basis for the commonly postulated zeolite facies, greenschist facies, and amphibolite facies layers of the oceanic crust.

\section{DEUTERIC MINERALS}

The minerals assigned to this group are volumetrically insignificant to minor. Mica was first identified in X-ray diffraction diagrams of vein-free total rocks. Subsequently tiny flakes of fresh, deep red-brown, highly pleochroic biotite were identified optically in Sample 321-14-4, 60-64 cm. Pleochroic flakes of uncertain identity were seen in all rocks in which mica was found by $\mathrm{X}$ -

TABLE 1

X-Ray Mineralogy of Veins from Hole 319

\begin{tabular}{|c|c|c|c|c|c|c|c|}
\hline $\begin{array}{c}\text { Sample } \\
\text { (Interval in } \mathrm{cm} \text { ) }\end{array}$ & Description & SMEC & MICA & $\begin{array}{l}\text { RML } \\
\text { MICA- } \\
\text { SMEC }\end{array}$ & CAL & ARAG & BIRN ( or CHL?) \\
\hline $13-1,68-72$ & Brown smectite vein & & M & M & $\mathrm{t}$ & & \\
\hline $13-1,88$ & Carbonate vein with $\mathrm{Mn}$ oxides & & & & M & & $\mathrm{t}$ \\
\hline $13-1,123-124$ & Red carbonate vein, $3 \mathrm{~mm}$ thick & $\mathrm{m}$ & & & M & & \\
\hline $13-1,136$ & White carbonate vein & $\mathrm{t}$ ? & & & M & $\mathrm{m}$ & \\
\hline $13-1,147-148$ & Carbonate vein & & & & M & & \\
\hline
\end{tabular}

Note: $\mathrm{ARAG}=$ Aragonite $; \mathrm{BIRN}=$ Birnessite $; \mathrm{CAL}=$ Calcite $; \mathrm{CHL}=$ Chlorite $; \mathrm{CPX}=$ Clinopyroxene, generally augite, but may be pigeonite or subcalcic augite in quenched, spherulitic rocks; Fo = Forsterite component of olivine; GOET = Goethite; HEM = Hematite; ILM = Ilmenite K-FLD = Potassium feldspar MARC = Marcasite; MT = Magnetite; PLAG = Plagioclase; PYR = Pyrite; QTZ = Quartz; RML = Random mixed layer; $\mathrm{SMEC} \mathrm{=} \mathrm{Smectite;}$ $\mathrm{TOD}=$ Todorokite. Approximate abundances estimated from X-ray peak heights $(\mathrm{Cu} \mathrm{K} \alpha): \mathrm{M}=$ Major component (roughly $30 \%$ or more); $\mathrm{S}=$ Subordinate component (roughly $15 \%$ to $30 \%$ ) $\mathrm{m}=$ Minor component (roughly $5 \%$ to $15 \%) ; t=$ Trace component, main X-ray reflections barely visible (less than $10 \%$ generally, less than $5 \%$ for minerals with intense reflections); ? = Generally means that presence of the mineral is uncertain if the question mark follows " $t$ "; in rare cases, especially following abundance symbols other than "t," it means that the identification of the mineral is uncertain. 
TABLE 2

X-Ray Mineralogy of Veins, Vugs, Total Rocks, Olivines, and Pseudomorphs from Hole 319A

\begin{tabular}{|c|c|c|c|c|c|c|c|c|c|}
\hline $\begin{array}{c}\text { Sample } \\
\text { (Interval in } \mathrm{cm} \text { ) }\end{array}$ & Description & SMEC & CHL & MICA & $\begin{array}{l}\text { RML } \\
\text { MICA- } \\
\text { SMEC }\end{array}$ & $\begin{array}{l}\text { RML } \\
\text { CHL- } \\
\text { SMEC }\end{array}$ & TALC & CAL & ARAG \\
\hline $5, \mathrm{CC}$ & Drusy colorless vein on palagonite (cavings) & $\mathrm{m}$ & & & & & & & \\
\hline 7 (cuttings) & Drusy phillipsite + earthy ochre palagonite (cavings) & $\mathrm{S}$ & & & & & & & \\
\hline $1-1,13-14$ & Carbonate + zeolite vein & $t$ & & & & & & M & \\
\hline $1-1,29-31$ & Waxy yellow smectite vein & M & $\mathrm{t}$ & & & & $\mathrm{m}$ & $\mathrm{t}$ & \\
\hline $1-1,110-112$ & Amber-yellow vein & t? & M & & & $\mathrm{m}$ & & & \\
\hline $1-1,113-114$ & Earthy yellow and red-brown vein & M & M & $\mathrm{t}$ ? & & & & $\mathrm{m}$ & \\
\hline \multicolumn{10}{|c|}{ Boundary of Cooling Units (0.5-m-thick pillow?) } \\
\hline $1-1,137$ & Lining of dikty taxitic vug & $\mathrm{m}$ & $\begin{array}{c}\mathrm{M} ? \\
(\mathrm{kaol} ?)\end{array}$ & & & & $\mathrm{S}$ & $\mathrm{S}$ & \\
\hline $2-1,10-11$ & Green cross-fiber vein & M & & M & & & & & \\
\hline $2-1,27-30$ & Total rock, dark gray & & & & & & & & \\
\hline \multicolumn{10}{|c|}{ Boundary of Cooling Units } \\
\hline $2-1,108-110$ & Calcite + green smectite vein, $2 \mathrm{~mm}$ thick & $\mathrm{S}$ & $\mathrm{m}$ & & & & $\mathrm{m}$ & $\mathrm{m}$ & $\mathrm{m}$ \\
\hline $2-1,136$ & Green smectite vein & M & & $\mathrm{S}$ & $\mathrm{m}$ & & & & \\
\hline $2-1,138$ & Green smectite vein & M & & $\mathrm{m}$ & & & & & \\
\hline $2-2,130-131$ & Cross-fiber vein & & & & & & & $\mathrm{m}$ & $\mathrm{M}$ \\
\hline $2-2,132-133$ & Radial prisms on joint surface & $\mathrm{S}$ & $t ?$ & & & & & $\mathrm{~m}$ & $\mathrm{M}$ \\
\hline $2-2,134$ & Conical, striated calcite & & & & & & & M & \\
\hline $2-3,39-40$ & Radial prisms + dark oxides & M & & & & & & $\mathrm{t}$ & M \\
\hline 3 (many depths) & Green smectite after olivine & M & & $\mathrm{t}$ ? & & & $\mathrm{m}$ & & \\
\hline $3-1,30-35$ & Rust-colored vein & M & & & & & & & \\
\hline $3-1,55$ & Brown and greenish-yellow vein & & & M & M & & & & \\
\hline $\begin{array}{l}3-1,73-78 \\
3-1,87-88\end{array}$ & Sulfide from vein & & & & & & & & $\mathrm{S}$ \\
\hline $\begin{array}{l}3-1,87-88 \\
3-1,120-124\end{array}$ & Green smectite vein & $M$ & & & & & & $\mathrm{t}$ ? & \\
\hline $\begin{array}{l}3-1,120-124 \\
3-2,20\end{array}$ & $\begin{array}{l}\text { Green to black smectite vein } \\
\text { Blue-green smectite vein }\end{array}$ & $\begin{array}{l}\mathrm{M} \\
\mathrm{M}\end{array}$ & & & & & & & \\
\hline $3-2,23-26$ & Blue-green vein & $\mathrm{M}$ & & & & & & $\mathrm{m}$ & \\
\hline $3-2,26$ & Sulfide from vein & & & & & & & & \\
\hline $3-2,62-63$ & Total rock, minor brown discoloration & & & & & & & & \\
\hline $3-2,85-86$ & Drusy carbonate vein & & $t^{\prime}$ ? & & & t? & & M & \\
\hline $3-2,127-130$ & Total rock, dark gray & & & & & & & & \\
\hline $3-4,18-21$ & Total rock, dark gray & & & & & & & & \\
\hline $3-4,125-129$ & Total rock, dark gray & & & & & & & & \\
\hline $\begin{array}{l}3-5,10-23 \\
3,145-148\end{array}$ & Fresh olivine (vs. LiF internal standard) & & & & & & & & \\
\hline $\begin{array}{l}4 \\
5,8-10\end{array}$ & Red smectite after olivine & M & & & & & $t ?$ & & \\
\hline $5,42-49$ & & & & & & & & & \\
\hline $3-5,42-46$ & Calcite + yellow-brown to red smectite vein & M & & & & & & M & $\mathrm{S}$ \\
\hline $3-5,98-103$ & Red-brown vein & & & $\mathrm{S}$ & $\mathrm{m}$ & & & & \\
\hline \multicolumn{10}{|c|}{ Boundary of Cooling Units (0.2-m-thick pillow?) } \\
\hline $3-5,133-142$ & Tan waxy smectite vein & M & $\mathrm{S}$ & & & & $\mathrm{m}$ & $\mathrm{m}-\mathrm{S}$ & \\
\hline $3-6,43-48$ & $\begin{array}{l}\text { Total rock, dark gray } \\
\text { Drusy to botry oidal carbonate lining irregular hole }\end{array}$ & & & & & & & & \\
\hline $3-6,92-93$ & $\begin{array}{l}\text { Drusy to botryoidal carbonate lining irregular hole } \\
\text { Carbonate vein with greenish-brown to brown }\end{array}$ & $\begin{array}{l}\mathrm{t} \\
\mathrm{S}\end{array}$ & & & & & & $M$ & \\
\hline $3-6,126-130$ & $\begin{array}{l}\text { Carbonate vein with greenish-brown to brown } \\
\text { smectite selvages }\end{array}$ & $\mathrm{s}$ & & & & & & M & M \\
\hline $3-6,143-149$ & Fresh olivine (vs. LiF internal standard) & & & & & & & & \\
\hline $4-1,93-127$ & $\begin{array}{l}\text { Fresh olivine (vs. LiF internal standard) with slight } \\
\text { range of composition }\end{array}$ & & & & & & & & \\
\hline $4-1,94-95$ & Carbonate + green smectite vein & $M$ & & & & & & $\mathrm{t}$ & M \\
\hline $4-1,111-114$ & Green smectite vein & M & & & & & & & \\
\hline $\begin{array}{l}4-1,114-119 \\
4-1,123\end{array}$ & $\begin{array}{l}\text { Black and minor green smectite }+ \text { goethite vein } \\
\text { Total rock, dark gray }\end{array}$ & M & $\mathrm{M}$ & & & & & & \\
\hline $4-1,129-132$ & $\begin{array}{l}\text { Colorless carbonate vein with selvages of brownish- } \\
\text { green, unoxidized smectite }\end{array}$ & $\mathrm{S}$ & & & & & & $\mathrm{m}$ & M \\
\hline $4-1,135$ & Cross-fiber lens in gray smectite vein & M & $\mathrm{t}$ & & & & & & $\mathrm{S}$ \\
\hline $5-1,58-59$ & $\begin{array}{l}\text { Green and black smectite vein with oxidized } \\
\text { walls or selvages }\end{array}$ & M & $\mathrm{m}$ & & & & & & \\
\hline $5-1,59$ & Brown oxidized smectite vein & M & $\mathrm{m}$ & & & & & & \\
\hline $5-1,59$ & $\begin{array}{l}\text { Aragonite layers in } 1-m m-\text { thick, green smectite } \\
\text { vein showing minor oxidation }\end{array}$ & M & & & & & & $\mathrm{t}$ & M \\
\hline \multicolumn{10}{|c|}{ Boundary of Cooling Units (top of pillowed section) } \\
\hline $\begin{array}{l}5-1,141-144 \\
5, C C\end{array}$ & $\begin{array}{l}\text { Carbonate vein with light brown smectite selvages } \\
\text { (Probably cavings; see top of Core 1) }\end{array}$ & $\mathrm{S}$ & & & & & & M & \\
\hline $6-1,122-127$ & Goethite(?) vein & $\mathrm{S}$ & & & & & & & \\
\hline \multicolumn{10}{|c|}{ Boundary of Cooling Units (top of 5-m-thick unit within pillowed section?) } \\
\hline $7-1,55-57$ & $\begin{array}{l}\text { Conical calcite in } 3 \text {-cm-long vug; } \\
\text { aragonite in other vugs nearby }\end{array}$ & & & & & & & M & (M) \\
\hline $7-1,107-108$ & "Sheared" green clay + carbonate vein & M & & & & & & & M \\
\hline $7-1,122$ & Red-brown + minor green smectite vein, $0.5 \mathrm{~mm}$ thick & M & & & & & & & \\
\hline \multicolumn{10}{|c|}{ Boundary of Cooling Units (bottom of 5-m-thick unit within pillowed section?) } \\
\hline $\begin{array}{l}7-1,143-148 \\
7 \text { (cuttings) }\end{array}$ & $\begin{array}{l}\text { Greenish-yellow smectite }+ \text { drusy phillipsite vein } \\
\text { (Probably cavings; see top of Core 1) }\end{array}$ & M & & & & & & & \\
\hline
\end{tabular}

Note: See Table 1 for explanation of symbols. 
TABLE 2 - Continued

\begin{tabular}{|c|c|c|c|c|c|c|c|c|c|c|c|c|}
\hline \multirow[b]{2}{*}{ PYR } & \multirow[b]{2}{*}{ MARC } & \multirow[b]{2}{*}{ GOET } & \multirow[b]{2}{*}{ QTZ } & \multirow[b]{2}{*}{ TOD } & \multirow[b]{2}{*}{ BIRN } & \multirow[b]{2}{*}{ PHIL } & \multirow[b]{2}{*}{ HEM } & \multirow{2}{*}{$\begin{array}{l}\text { Unknowns } \\
(2 \theta, \mathrm{Cu} \mathrm{K \alpha})\end{array}$} & \multirow[b]{2}{*}{ Others } & \multicolumn{3}{|c|}{$\begin{array}{c}\text { Vein-Free } \\
\text { Total Rocks }\end{array}$} \\
\hline & & & & & & & & & & MT & SMEC & MICA \\
\hline & & & 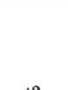 & & & $\begin{array}{l}\mathrm{M} \\
\mathrm{M} \\
\mathrm{S}\end{array}$ & & & & & & \\
\hline & & & & & & & & $4.4^{\circ}$ (boehmite & & & & \\
\hline
\end{tabular}

PLAG, CPX

OLIVINE $\quad t$

t

$21.3^{\circ}$

M

m

M

M S

$\begin{array}{cccc}\text { ARAG? } & & \mathrm{m} & \mathrm{t} \text { ? } \\ \text { ILM. } & \mathrm{m} & \mathrm{S} & \\ \text { ARAG? } & \mathrm{m} & \begin{array}{l}\mathrm{m}-\mathrm{S} \\ \mathrm{m}-\mathrm{S}\end{array} & \mathrm{t} \\ \text { Fo } 84 \pm 0.5 & & & \\ \text { OLIVINE } & & & \end{array}$

M

m $\quad \mathrm{m}-\mathrm{S}$

Fo $84 \pm 0.0$

Fo $84 \pm 1.0$

M

$21.1^{\circ}$

ILM? m m

$\mathrm{m}$

$21.0^{\circ}$

$t-m$

M

t?

$\stackrel{M}{M}$ 


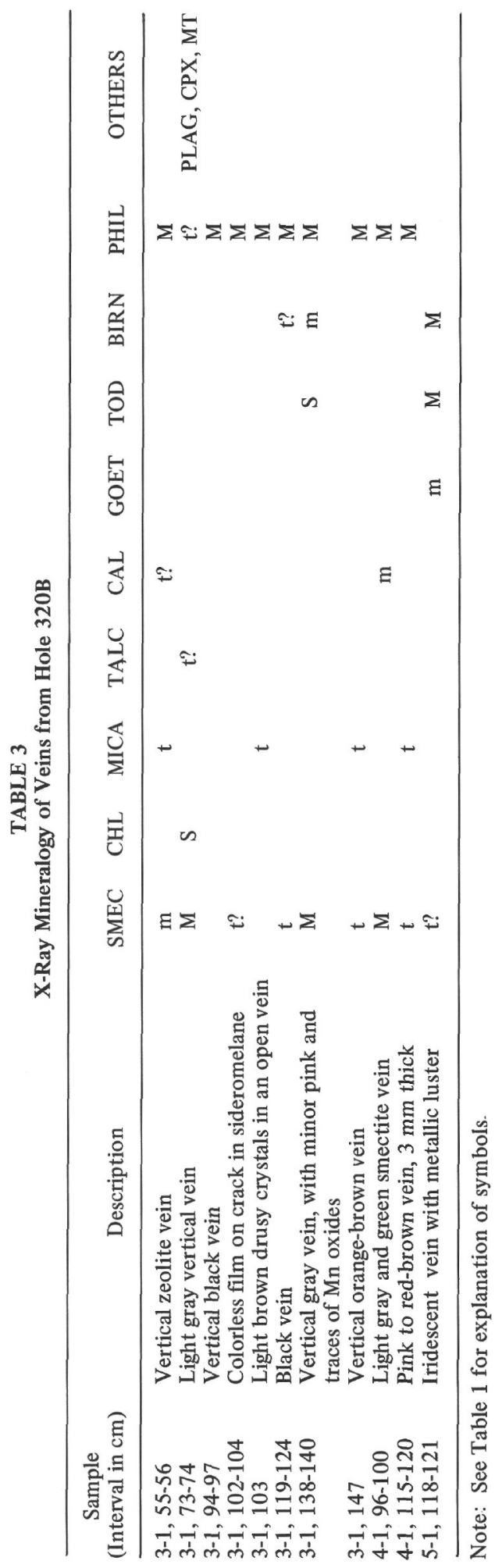

ray analysis and in several others as well. All are coarsegrained basalts and fine- to medium-grained diabases with smectite-rich mesostases; deuteric effects are more likely in such rocks than in finer grained marginal facies of the same cooling units. The smectite probably represents diagenetically altered glass, but some of it may represent a quench phase of the type commonly synthesized during quenching of experimental runs on hydrous basalt compositions (e.g., Yoder and Tilley, 1962, p. 440-446).

Neither amphibole nor chlorite was identified among the deuteric minerals with the basalts and diabases themselves. However, certain chlorite-rich veins from Holes 319A and 320B are assigned a probable deuteric origin. They are generally paper thin, discontinuous veins composed predominantly of chlorite (the $14 \AA \mathrm{X}$ ray peak is generally obscured by the main peak of associated smectite, but the minerals are probably chlorite rather than serpentine or some other $7 \AA$ phase). They vary in color from dark green or black (fresh) to tan or yellow (altered). Associated minerals are mainly smectite and rarely talc (319A-3-5, 133-142 cm). The smectite may be deuteric or a later alteration product of the chlorite or some other deuteric mineral. In 319A-1-1, $110-112 \mathrm{~cm}$, the alteration products include a randommixed-layer chlorite-smectite. In the freshest such vein (319A-4-1, 114-119 cm), the chlorite and smectite are intergrown with and replaced by spherules of goethite. Oxygen isotope ratios $\left(\delta \mathrm{O}^{18}, \mathrm{SMOW}\right)$ of a mixture of chlorite $(80 \%)$ and goethite $(20 \%)$ from this vein (the only one from which a large enough concentration of chlorite for isoto ic analysis could be obtained) and of a concentrate of goethite $(321-14-1,11-16 \mathrm{~cm})$ are 18.9 and 17.5 per mil, respectively (Muehlenbachs, this volume). If the goethite from Hole $319 \mathrm{~A}$ is isotopically similar to that from Site 321, then the chlorite from Hole $319 \mathrm{~A}$ has a $\delta \mathrm{O}^{18}$ value considerably less than those of clays formed in isotopic equilibrium with seawater (about 25 per mil), and the isotopic evidence supports the inference that the chlorite is deuteric. An unknown mineral in one of the veins (319A-1-1, 113-114 cm;20, $\operatorname{CuK} \alpha=14.4^{\circ}$ ) may be boehmite. If so, it is probably an alteration product of some earlier vein component. There is a weak suggestion of the preferential occurrence of deuteric chlorite in thin cooling units or near the boundaries of thicker units. The number and distribution of samples are inadequate to confirm the suggestion, which, if real, may reflect the migration of late hydrous fluids either into or out of the cooling unit, depending on the source of water, the location and time of formation of cooling cracks, and the direction in which the cracks propagated as they formed (i.e., inward or outward).

The mineral assemblage lining one diktytaxitic vug $(319 \mathrm{~A}-1-1,137 \mathrm{~cm})$ includes smectite, talc, and a phyllosilicate which may be serpentine, kaolinite, or another $7 \AA \AA$ mineral rather than chlorite. Its great abundance and the fact that the association montmorillonite-kaolinite can form by hydrolytic decomposition of the plagioclase lining of the vug over a broad range of conditions (Hemley, 1959; Hemley and Jones, 1964) suggests that the lining may be either deuteric or pneumatolytic. 
Iddingsite occurs in $319 \mathrm{~A}-3-2,127-130 \mathrm{~cm}$, as orangebrown rims on pseudomorphs after large grains of olivine or as the entire pseudomorph after small groundmass grains of olivine. The iddingsite in any given rim or pseudomorph extinguishes simultaneously and is probably a single crystal of Fe-pigmented smectite. It reflects a stage of oxidation at or near the end of primary crystallization of the magma, presumably related to a high water content, the dissociation of water, and the diffusional loss of hydrogen. If so, then the iddingsite is properly as much deuteric as it is primary. The high-temperature oxidation of titanomagnetite, with formation of exsolution lamellae of ilmenite (see Ade-Hall et al., Petrography of Opaque Minerals, this volume), probably belongs to the iddingsite-forming or a slightly earlier stage.

\section{PREBURIAL SEAWATER ALTERATION PRODUCTS}

The main phases from Leg 34 assigned to this group are the palagonite from Holes $319 \mathrm{~A}$ and $320 \mathrm{~B}$ and some oxidatively altered olivines. This interpretation is commonly accepted today for most palagonite. However, it is at variance with certain early views and its basis and implications merit some discussion.

Eruptions which transgressed the sediment-seawater interface onto the ocean floor, or were erupted below a thin, disturbed sediment blanket, reacted with oxygenated bottom water during primary cooling and, subsequently, until later flows or a thicker sediment blanket restricted such free interaction. Reactions during primary cooling, especially leaching, are widely postulated to account for special types of sediments, and such leaching finds support in enhanced Fe concentrations in seawater collected adjacent to Kilauean lavas which recently entered the sea (Moore et al., 1973, note added in proof, p. 545-546; R.W. Grigg, personal communication, 1973). However, such reactions leave no known trace in the basalt itself except possibly for the opaque minerals adjacent to veins and cracks which were oxidized at high temperatures (Ade-Hall et al., Petrography of Opaque Minerals, this volume) and which Ade-Hall ascribes to interaction with seawater entering primary cooling cracks. Despite early suggestions that palagonite formed during primary cooling, the results of dredging and coring at and near the crests of spreading ridges and along the East Rift Zone of Kilauea Volcano (Moore, 1966) reveal palagonite-free sideromelane forming primary cooling surfaces that were in contact with seawater. Therefore, we may infer that palagonite dredged from somewhat older, but still unburied or shallowly buried rocks, which are otherwise identical to the palagonite-free rocks, represents the product of seawater alteration at ambient bottom-water temperatures. While elevated temperatures undoubtedly accelerate the process, the duration of those temperatures is normally too short to effect a notable increase in palagonite thickness.

The common color banding in palagonite suggests a diffusion controlled process of formation, whereby the inner surface of the palagonite advances into the adjacent sideromelane. Thus, the thickness of palagonite should increase monotonically with time except where spalled off. On this basis Moore (1966) proposed an empirically based equation to relate thickness to the time since eruption. While this may work with reasonable accuracy for young eruptions, it requires finding a primary cooling surface rather than a spalled surface or the surface of a secondary crack which may have opened any time subsequent to eruption and thus "reset" the palagonite clock. Furthermore, the banded palagonite is chemically inhomogeneous and may have variable diffusion coefficients for mobile elements, so that the rate of formation may not be a simple, smooth function of time, and those diffusion coefficients may also depend critically on temperature (Friedman et al., 1966).

Most young palagonite, whether formed in salt or fresh water, is amorphous to X-rays. Older palagonite is a mixture of amorphous material and poorly crystallized smectite. X-ray smear-slide analyses of such smectite gives patterns indicative of essentially randomly oriented aggregates. Evidently the smectite nucleated at many sites but did not grow readily, so that the powder formed by grinding the palagonite is controlled by the conchoidal fracture of the amorphous glass-like colloid rather than the smectite cleavage. These palagonites are red, orange, brown, or yellow. In some cases (e.g., Leg 17. Holes 166, 169, 171; see Bass et al., 1973a, p. 462, $467,471)$ essentially gray or green palagonite occurs, again with poorly crystallized smectite and rarely with a mica-smectite random-mixed-layer (RML) phase. Such palagonite is essentially identical to more common palagonite except for color and appears to have formed after burial, when access to oxygen was restricted or nil, thus lending support to the interpretation that the common red and brown palagonites formed before burial by direct reaction of sideromelane with seawater. It must not be assumed immediately that all old green glasses are necessarily nonoxidative palagonites formed from originally brown sideromelane, as evidence by green Triassic basalt glass from Alaska (Brew and Muffler, 1965; Muffler et al., 1969), although the $1.58 \% \mathrm{H}_{2} \mathrm{O}+$ in the glass, most of it probably secondary, indicates that it is somewhat altered. Some gray or green palagonite is banded, and it is conceivable that it formed directly from sideromelane, or by reduction and leaching of $\mathrm{Fe}$ from earlier formed normal palagonite.

All palagonite from Leg 34 is red, brown, or yellow; is commonly massive rather than banded; and is in contact with fresh sideromelane. Palagonite formation evidently did not progress far after burial of the basement. In rocks from Hole 320B the palagonite was recovered essentially in place. In the recovery from Hole 319A, on the other hand, all palagonite is believed to be displaced. It occurs as large platy fragments typically coated by phillipsite veins with traces of carbonate. It appeared as cavings, along with those of fine-grained chilled basalt, in the core catchers of every core, or was caught in a bucket with the water from the liners of cores with partial recovery. The advent of severe sticking of the bit and ultimate loss of Hole 319A correlates with a deluge of the large cuttings (up to $2.5 \mathrm{~cm}$ maximum dimension) of palagonite (plus sideromelane and phillipsite) and chilled basalt, which is only rarely veined by phillipsite. 
TABLE 4

X-Ray Mineralogy of Veins, Amygdules, and Total Rocks from Site 321

\begin{tabular}{|c|c|c|c|c|c|c|c|c|c|c|}
\hline $\begin{array}{c}\text { Sample } \\
\text { (Interval in } \mathrm{cm} \text { ) }\end{array}$ & Description & SMEC & CHL & MICA & $\begin{array}{l}\text { RML } \\
\text { MICA- } \\
\text { SMEC }\end{array}$ & $\begin{array}{l}\text { RML } \\
\text { CHL- } \\
\text { SMEC }\end{array}$ & TALC & CAL & ARAG & PYR \\
\hline $13-4,119-124$ & Green, blue, and tan smectite veins & M & & $\mathrm{S}$ & & & & & & \\
\hline $13-4,120-125$ & Golden yellow smectite amygdules and pseudomorphs & $\mathrm{M}^{\mathrm{a}}$ & & & & & & & & \\
\hline $13-4,127-132$ & Brown and yellow smectite $+\mathrm{Mn}$ oxide veins & M & & M & & & & & & \\
\hline $13-4,127-132$ & Red-brown Fe oxide veins & $\mathrm{m}$ & & & & & & & & \\
\hline $13-4,127-132$ & Black Mn oxide veins & M & & & & & & & & \\
\hline $13-4,127-132$ & Total rock, fine-grained, 2-mm medium gray-brown rind & & & & & & & & & \\
\hline $13-4,127-132$ & $\begin{array}{l}\text { Total rock, fine-grained, brownish-gray core, slightly } \\
\text { vesicular }\end{array}$ & & & & & & & & & \\
\hline $14-1,9-15$ & White carbonate + ochre Fe oxide + "rust" vein & $\mathrm{t}$ & & & & & & M & & \\
\hline $14-1,17$ & Granular carbonate vein & & & & & & & M & & \\
\hline $14-1,25-26$ & Cross-fiber carbonate vein & $\mathrm{t}$ ? & & & & & & M & & \\
\hline $14-1,48$ & Granular, colorless vein & $\mathrm{m}$ & & & & & & $\mathrm{S}$ & & $\mathrm{t}$ \\
\hline $14-1,50$ & Zeolite vein & $\mathrm{S}$ & & & & & & $\mathrm{t}$ ? & & \\
\hline $14-1,62$ & Blue-green botryoidal "smectite" vein & $\mathrm{S}$ & $\mathrm{t}$ & $\mathrm{M}(1 \mathrm{M})$ & & & & & & \\
\hline $14-1,70$ & Sulfide + dark green smectite vein & M & & & & & & & & $\mathbf{M}$ \\
\hline $14-1,74-76$ & Sulfide + blue-green smectite vein & M & & & & & & & & M \\
\hline $14-1,86-92$ & Carbonate amygdules with green smectite & $\mathrm{m}$ & & & & & & M & & $\mathrm{t}$ ? \\
\hline $14-1,87$ & Carbonate + zeolite from smectite vein & M & & & & & & M & & $t$ \\
\hline $14-1,113-121$ & Sulfide + zeolite from vein & $\mathrm{t}$ & & & & & & & & M \\
\hline $14-1,125$ & $\begin{array}{l}\text { Carbonate }+ \text { green and minor brown smectite vein, } \\
2 \mathrm{~mm} \text { thick }\end{array}$ & M & $\mathrm{t}$ ? & $\mathrm{m}$ & & & & M & & \\
\hline $14-2,19-29$ & Carbonate amygdules with green smectite and sulfide & $\mathrm{m}-\mathrm{S}$ & & & & & & M & & $\mathrm{S}$ \\
\hline $14-2,19-29$ & Sulfide vein & & & & & & & & & M \\
\hline $14-2,42$ & Carbonate vein with blue-green smectite and sulfide & $\mathrm{m}-\mathrm{S}$ & & & & & & M & & \\
\hline $14-2,53$ & Red smectite from center of blue-green smectite vein & $\mathrm{S}$ & & & & & & & & \\
\hline $14-2,58-63$ & Total rock, dark gray & & & & & & & & & \\
\hline $14-2,70-72$ & Blue-green smectite vein & M & $\mathrm{t}$ & $\mathrm{s}$ & & & $\mathrm{t}$ & $\mathrm{t}$ ? & & \\
\hline $14-2,74-150$ & Dark green and gray smectite veins with sulfide & M & & & & & & $\mathrm{m}$ & & $\mathrm{S}$ \\
\hline $14-2,74-150$ & $\begin{array}{l}\text { Concentration of light blue-green smectite from centers } \\
\text { of veins }\end{array}$ & M & $\mathrm{m}$ & & & $\mathrm{t}$ & & & & \\
\hline $14-2,83$ & $\begin{array}{l}\text { Blue-green smectite vein enclosing carbonate } \\
\text { scalenohedra }\end{array}$ & M & & & & & $\mathrm{t}$ & M & & \\
\hline $14-2,94-97$ & Total rock, dark gray & & & & & & & & & \\
\hline $14-2,94-97$ & $\begin{array}{l}\text { Green smectite + calcite vein with brown smectite } \\
\text { selvages }\end{array}$ & M & t & & & & t & $\mathrm{M}$ & & \\
\hline 14-2, 101 & Dark blue-green smectite + carbonate vein & $\mathrm{M}$ & $\mathrm{t}$ & $\mathrm{S}$ & & & $\mathrm{m}$ & M & & \\
\hline $14-2,138$ & Gray-green smectite + sulfide vein & M & & & & & & & & M \\
\hline $14-3,7-10$ & Total rock (few or no carbonate amygdules), dark gray & & & & & & & & & \\
\hline $14-3,37-50$ & Carbonate amygdules + minor green smectite & $\mathrm{S}$ & & & & & & M & & m \\
\hline $14-3,80-100$ & Dark green smectite veins with light blue centers & M & $\mathrm{m}$ & & & $\mathrm{m}$ & $\mathrm{m}$ & & & $\mathrm{t}$ \\
\hline $14-3,80-100$ & Concentration of dark green and gray-green smectite & M & & & & & & & & \\
\hline $14-3,80-100$ & Concentration of medium grayish-blue smectite & M & $t$ & & & & $\mathrm{t}$ & & & \\
\hline $14-3,80-100$ & $\begin{array}{l}\text { Concentration of light blue-green often rod-like } \\
\text { smectite from centers of veins }\end{array}$ & M & $\mathrm{m}$ & & & & & $\mathrm{t}$ & & \\
\hline $14-3,80-100$ & $\begin{array}{l}\text { Concentration of brown, striated, polished smectite } \\
\text { lenses in the dark green smectite }\end{array}$ & M & & & & & & & & \\
\hline $\begin{array}{l}14-3,92-112 \\
14-3,100\end{array}$ & $\begin{array}{l}\text { Carbonate amygdules with green smectite and sulfide } \\
\text { Total rock, dark gray, vein-free, but } 2 \text { to } 4 \mathrm{~mm} \text { from } \\
\text { thick green smectite vein }\end{array}$ & M & & & & & & M & & $\mathrm{m}$ \\
\hline $14-3,111$ & Carbonate vein with green smectite and sulfide & M & & & & & & $\mathrm{M}$ & & $t$ \\
\hline $14-3,120-124$ & Dark gray smectite vein & M & $\mathrm{t}$ & & & & & & & \\
\hline $14-3,126-130$ & Light blue-green botry oidal smectite & M & $\mathrm{m}$ & & & & $\mathbf{t}$ & & & \\
\hline $14-4,30-33$ & Total rock (dark gray) with green smectite amygdules & & & & & & & & & \\
\hline $14-4,57$ & Dark greenish-gray + light blue smectite vein & M & $\mathrm{t}$ & & & & & & & \\
\hline $14-4,60-64$ & Total rock (dark gray) with green smectite amygdules & & & & & & & & & \\
\hline $14-4,60-64$ & $\begin{array}{l}\text { Smectite amygdules, light gray-green to blue-green, } \\
\text { grading out to dark green rims }\end{array}$ & M & & & & & & & & \\
\hline
\end{tabular}

Note: See Table 1 for explanation of symbols.

${ }^{\mathrm{a}}$ Includes amygdules, vesicle linings, and pseudomorphs after olivine microphenocrysts.

The debris is believed to be from a single horizon of fractured pillows and porous, poorly cemented hyaloclastite (perhaps interpillow material) near or at the top of the basement which had been slowly caving throughout the drilling, thereby enlarging the hole at that horizon. During or after repair of the Bowen power sub, the debris built up in the bottom of the hole, either by a continued trickle of debris that was not ground up during the lapse in drilling, or by a sudden collapse of the weak layer into the hole which, by then, had been greatly enlarged by the earlier slow caving. The collapse may have occurred immediately after the repair of the Bowen power sub when the bit, which had been raised above the basement during repairs, hung up momentarily at the sediment-basalt contact when it was lowered. Upon lowering the bit to the bottom of the hole and resumption of drilling, the bit encountered more debris than it could cope with. Consistent with this reasoning, all phillipsite-coated palagonite is assigned to the top of the basement (see Table 2), regardless of the core with which it was recovered.

The palagonite described above formed from chilled, surficial sideromelane with a bulk composition near that of the originally erupted magma. In the interior of the 
TABLE 4 - Continued

\begin{tabular}{lccccccc}
\hline MARC GOET QTZ TOD BIRN PHIL HEM & Unknowns & \multicolumn{3}{c}{ Vein-Free } \\
Total Rocks \\
\end{tabular}

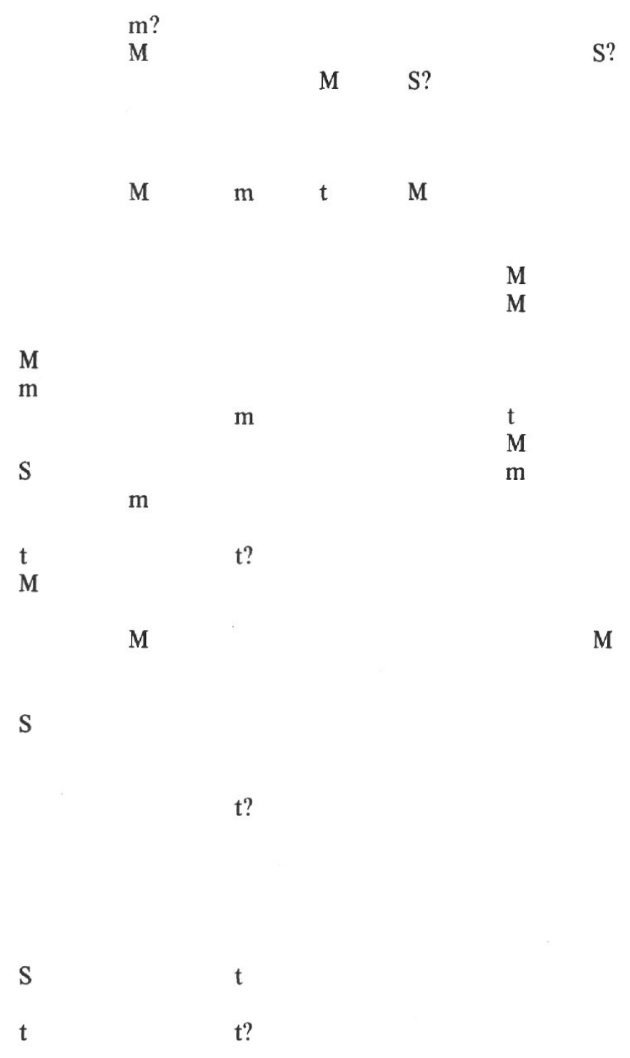

\section{$21.2^{\circ}$}

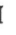

.

flows, however, we find glass formed from residual pockets of magma. Such glass formed interstitially in the layer of spherulites immediately below the surficial sideromelane, and as the last mesostasis in the coarser grained interior parts of pillows and flows. Relative to the original magma the interstitial glass in coarser grained rocks is commonly purple or purplish brown, is rich in $\mathrm{Fe}, \mathrm{Ti}$, and water, and has a relatively high $\mathrm{Fe}^{+3} /\left(\mathrm{Fe}^{+3}+\mathrm{Fe}^{+2}\right)$. As a result it is more susceptible to hydration than the surficial, more resistant, Mg-richer sideromelane, and, in contrast to the sideromelane, of which reminants commonly survive, it almost never survives except in the youngest rocks from ridge crests or, in the case of older flows, in the centers of large joint blocks of quenched basalt. The interstitial glass remnants in the relatively quenched rocks may owe their survival to an intermediate degree of resistance to alteration arising from a more magnesian composition than that of the easily altered, more fractionated interstitial glass in the more slowly cooled rocks. In rare cases the remnants are devitrified (as in 319-13-1, 97-101 cm, piece 7).

Near free surfaces, where interaction with oxygenated water is possible, the interstitial glass may be altered to red or brown palagonite, but more commonly it is altered to golden yellow palagonite which appears to reflect limited access or absence of free oxygen. In the relatively quenched rocks with surviving glass remnants, 


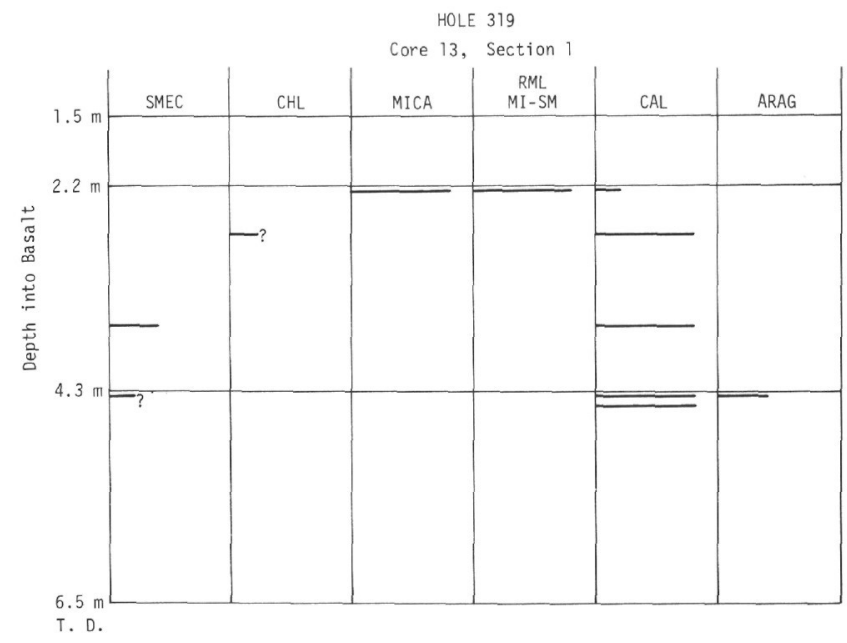

Figure 1. Graphical representation of the data in Table 1. Thick lines represent inferred boundaries of cooling units. Relative abundances of minerals are approximate (see Table 1).

one may see sharp diffusion boundaries between the glass and homogeneous or, rarely, color-zoned golden yellow palagonite (as in 319-13-1, 84-85 cm, piece 5). Unlike the more resistant sideromelane, the interstitial glass has a greater tendency to be altered to smectite. As a result it rapidly becomes anisotropic, at first vaguely so, but soon by development of discrete flakes of green to brownish-green to brown smectite which are visible under the petrographic microscope and, in some relatively coarse-grained flakes in older rocks, are often visibly pleochroic. This material constitutes the socalled "fibropalagonite," an apt name despite the fact that the crystallites are not usually fibrous but flaky. The golden yellow palagonite and green to brown fibropalagonite are the main components giving rise to the color banding of joint blocks commonly seen in both dredged and drilled oceanic basalts. These types of alteration products occur widely in the rocks from Holes 319 and 320B where quenched to fine-grained rocks are common, and less so in those from Hole 319A and Site 321 where relatively fine-grained rocks are less common. These products are distinct from those in the interstices of the coarser grained rocks, both mineralogically and in the absence of enclosed late, interstitial, skeletal crystals of plagioclase and opaque minerals and strongly purpletinted grains of titanaugite. Either the coarse-grained rocks were in contact with bottom water for an inadequate time prior to burial to develop the types of alteration products seen in the quenched rocks, or the more fractionated interstitial material in the more slowly cooled rocks was converted to other secondary products during primary cooling, so that little or no interstitial glass survived to undergo the type of low temperature alteration seen in the finer grained rocks nearer the surfaces of cooling units (as mentioned above, some of the interstitial smectite in coarse-grained rocks may be of quench origin).

The only phase beside glass which records preburial seawater alteration is olivine, which is commonly altered to an earthy, often porous mass of $\mathrm{Fe}$ oxides in near- surface sites where the olivine was exposed to oxygenated water. These pseudomorphs are commonly washed out during drilling, leaving nondescript holes, or are lost during grinding of thin sections due to a tendency to wash out the oxides and pluck the sides of the holes. They are best preserved where the olivine is only partially altered and especially if it is entirely enclosed in sideromelane and exposed to seawater attack only through a hairline crack. The olivine then yields a pseudomorph rimmed by a thin zone of palagonite surrounded in turn by sideromelane. These may survive during the grinding of thin sections. In the interior of the basalt any olivine present is altered simultaneously with the formation of golden yellow palagonite and fibropalagonite from interstitial glass. Due to the absence or limited availability of oxygen, the olivine, like the glass, alters to smectite rather than earthy $\mathrm{Fe}$ oxides, and the smectite is generally green to brown fibropalagonite or faintly birefringent golden yellow smectite of the types which replace the glass, and indistinguishable therefrom except by pseudomorphic outline (as in Sample $321-13-4,120-125 \mathrm{~cm})$. In many cases the olivine is altered only along edges and cracks in those areas of rocks where the surrounding mesostasis is wholly altered, indicating that olivine of the composition commonly found as microphenocrysts in oceanic tholeiites (in the range $\mathrm{F}_{82}-\mathrm{FO}_{87}$ usually) reacts with seawater more slowly than Fe-rich interstitial glass. Ultimately, the olivine goes to pseudomorphs which, while typically at least as crystalline as the fibropalagonite replacing glass and commonly more so, are distinguishable from it with certainty only where the subhedral or euhedral shape allows a distinction (this problem was discussed and illustrated by Bass et al., 1973a, in connection with rocks from Sites 167 and 171). The small groundmass olivines in the rocks cored during Leg 34 are invariably wholly altered, due undoubtedly in part to their small sizes, but probably in part also to the fact that they are Fe-richer than the phenocrysts and microphenocrysts, hence more susceptible to alteration, like the late interstitial glass. The altered olivines may have mesh textures like that commonly seen in serpentine pseudomorphs after olivine. These were described and illustrated in pseudomorphs after olivine phenocrysts and microphenocrysts in rocks from Hole 171 by Bass et al. (1973a). In the coarser grained rocks from Hole 319A and Site 321, such mesh textures are seen even in the smallest groundmass pseudomorphs.

\section{OXYGEN SUPPLY BELOW THE SEDIMENT- WATER INTERFACE}

In the interiors of unburied flows and throughout buried ones water devoid of free oxygen reacts with various phases. The absence of oxygen is due to several causes, chief among which are low permeability and the presence of chemical impediments to the ingress of oxygen from the source to the rocks in question.

Low permeability is present in nonvesicular rocks and in those which were not previously fractured, sheared, or weathered.

Oxygen impediments are of several types. Chemical sinks are substances which react with oxygen and reduce the available oxygen molecules. If the reaction rate is 
HOLE 319A

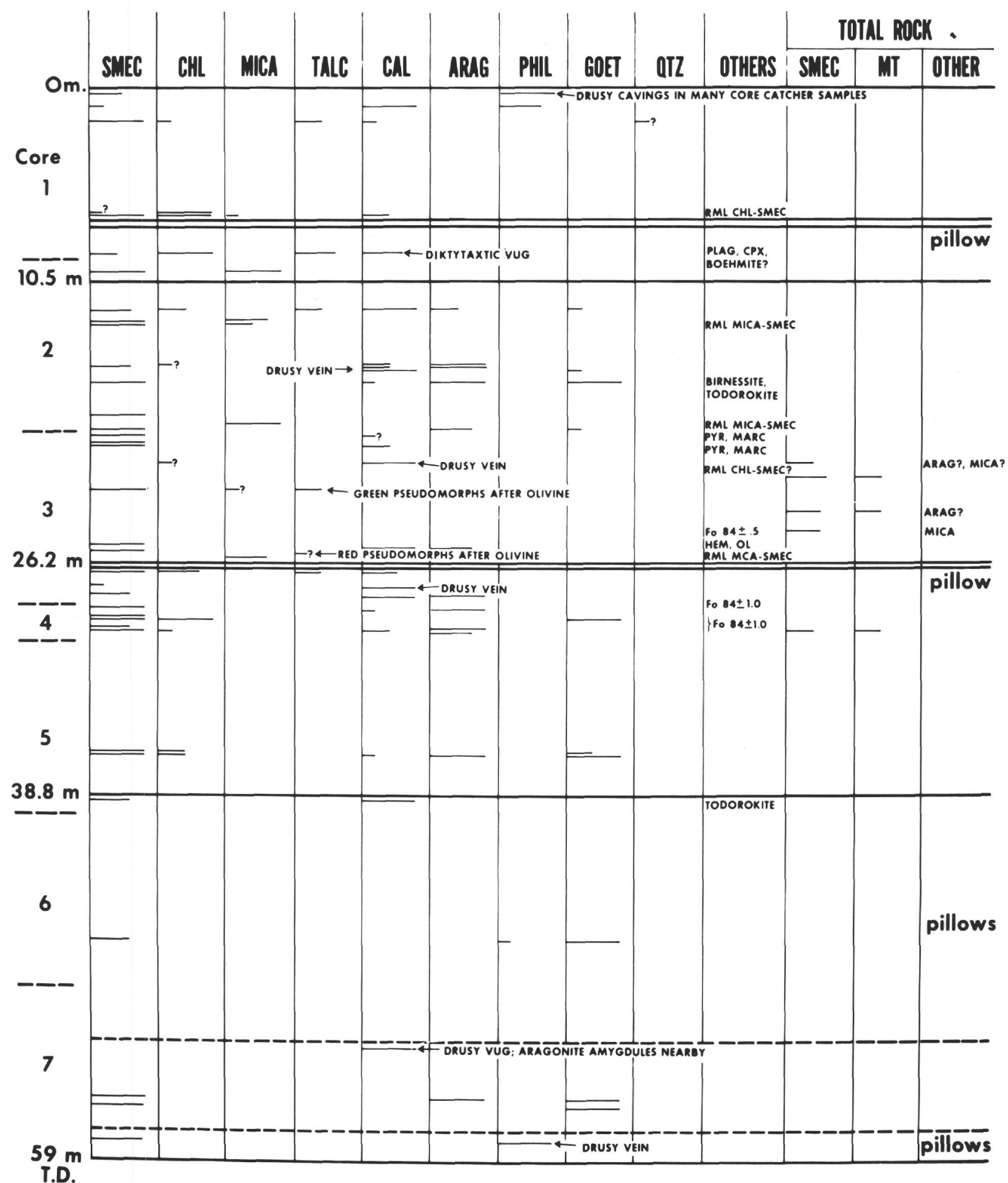

Figure 2. Graphical representation of the data in Table 2. Thick lines represent inferred boundaries of cooling units; dashed thick lines are less certain boundaries than the others. Relative abundances of minerals are approximate (see Table 1).

rapid, a sharp oxidation front develops and, where color differences result from oxidation, the front is visible. If the sink both reacts rapidly and is sufficiently abundant relative to the oxygen supply, it is effectively a buffer that must be completely consumed along the front before the front can advance. In a sense, such fronts record the "titration" of the chemical sinks with oxygen. Inorganic sinks are primarily ferrous iron and sulfide in 
HOLE 32OB

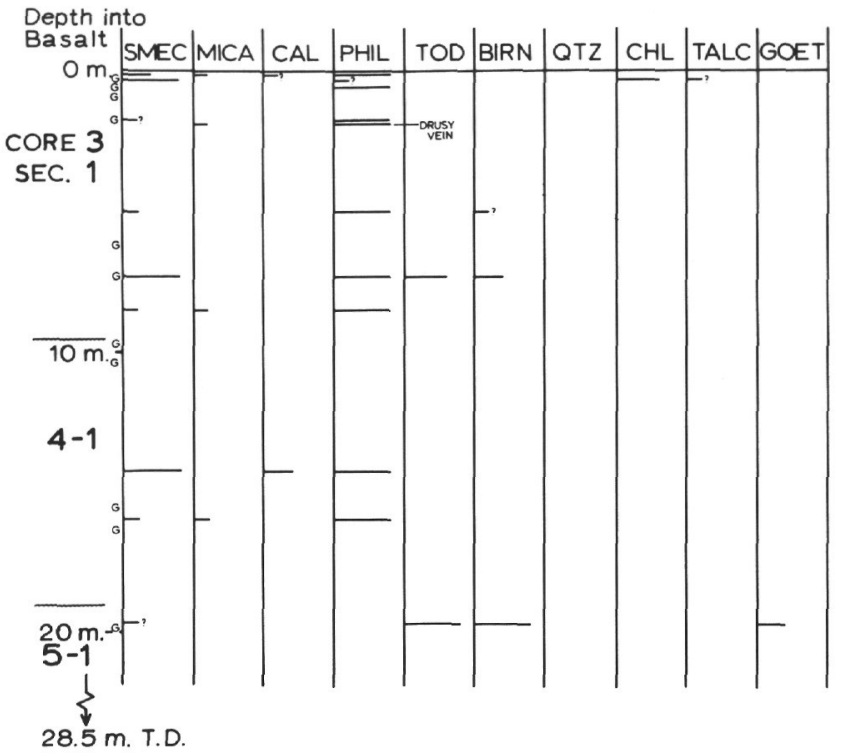

Figure 3. Graphical representation of data in Table 3. Cooling unit boundaries are indicated by occurrences of glass (G). Relative abundances of minerals are approximate (see Table 1). fresh basalts, and ferrous iron, sulfide and organic matter in sediments. The ferrous iron in sediments is in some small measure brought in with land-derived detritus, but, for the most part, is brought in with locally derived volcanic detritus. Sulfide may be brought in with such detritus, but is commonly oxidized during transport and, therefore, little of the sediment sulfide is derived from land or basalt. Most of it forms by bacterial reduction of sulfate and sulfur-bearing organic matter. The organic matter may be land derived in hemipelagic sediments or in turbidities from shelf areas, but in pelagic sediments it represents whatever organic material from surface-water productivity survives settling through the water column. The latter contribution is minor except under regions of exceptionally high productivity.

Thus, given a sediment column, the downward access of oxygen to a certain level within or below the sediments is limited by the amount and reactivity of chemical sinks, the thickness of the sediment column (which is a diffusion retarder), the diffusion coefficient of oxygen through the interstitial water, the porosity of the sediment (which may be high near the surface and less at depth), and the upward counterflow of water displaced from the compacting sediments at depth. Accordingly, given a sufficiently high sedimentation rate,

\section{HOLE 321}

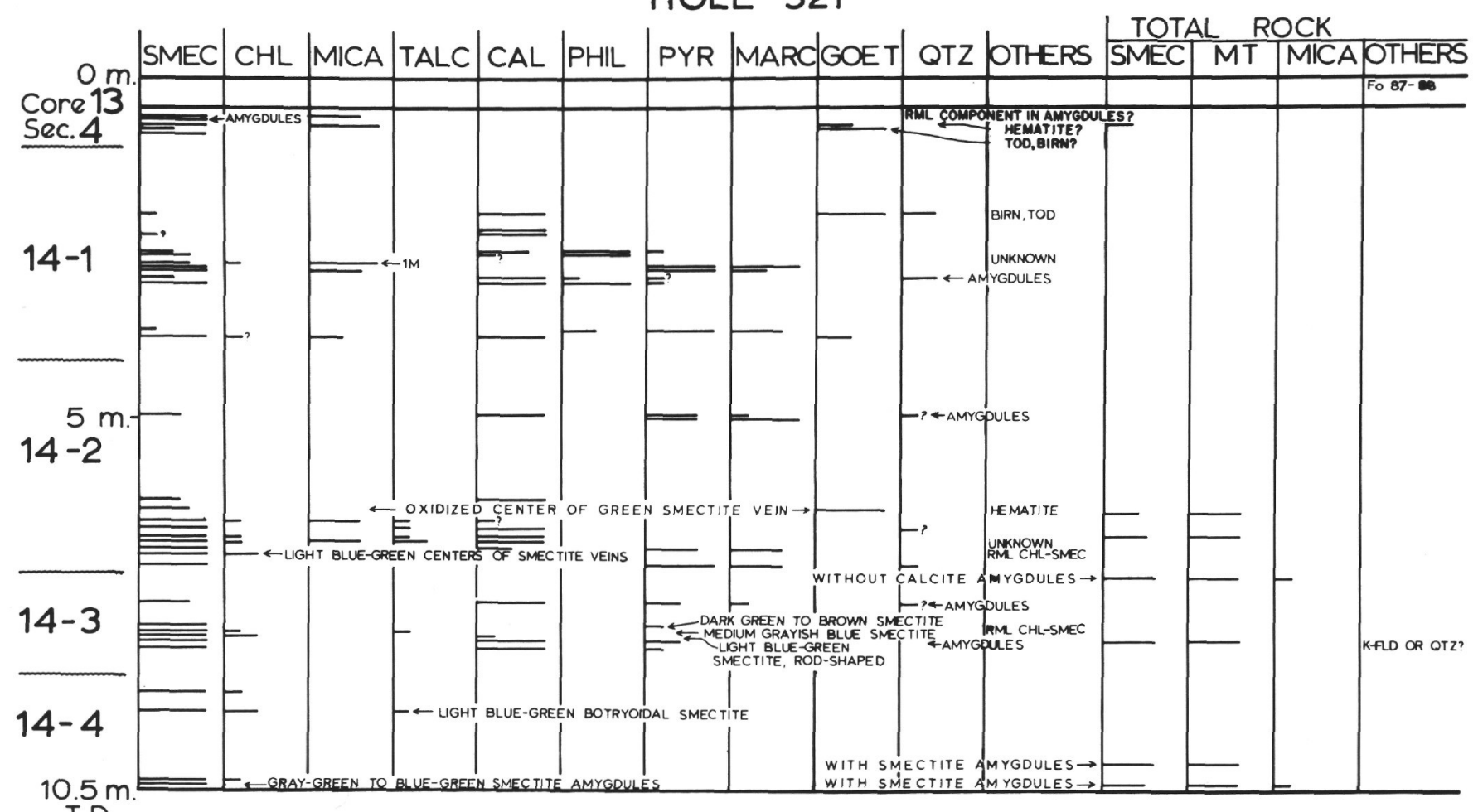

T.D.

Figure 4. Graphical representation of data in Table 4. Since drafting this figure the writer decided that the cooling unit boun-

dary, shown by the thick line, should be at $125 \mathrm{~cm}$ in Core 13. Section 4, rather than at $118 \mathrm{~cm}$, as shown (the interval $118-125 \mathrm{~cm}$ is olivine normative, in contrast to the uniformly quartz-normative chemistry of all underlying rocks; see Rhodes et al., this volume); thus, the first two veins in Table 4 should be in the thin upper unit. The olivine composition for that unit (Fo 87-88) is not shown in Table 4. Relative abundances of minerals are approximate (see Table 1). 
the sediments may increase in thickness faster than the diffusion rate, and the influx of oxygen below a certain level is effectively nil. This probably does not occur in pelagic areas floored by red clays and oozes below areas of low productivity.

Alternatively, a sufficiently high rate of sedimentation of organic matter and other chemical sinks for oxygen may provide a semi-infinite buffer which will never be penetrated by oxygen from above, so that, once all oxygen is consumed at a certain level, nonoxidative conditions prevail indefinitely and, given sufficient organic matter, reducing conditions may develop. This condition is found in the bottom waters of closed, euxinic basins and below thick hemipelagic aprons. The basalts under such areas should show little or no oxidative alteration postdating the consumption of the oxygen originally present in connate waters. In most abyssal areas, however, the sedimentation rate of chemical sinks is low, and most potential sinks are wholly oxidized by the time they are deposited at the sediment-water interface. Thus, abyssal sediments tend to be completely oxidized, but not oxidizing (the metalliferous sediments of the Bauer Deep are good examples). Exceptions occur under regions of exceptionally high productivity and in those areas where turbidity currents can introduce sediments rich in organic matter and/or unoxidized volcanic debris from islands or continents. In the latter instance the oxidizable layers are finite rather than semiinfinite and retard the downward diffusion of oxygen only temporarily (depending on the rate of influx of turbidity currents and the supply of available source material rich in organic matter). Thus, oxygen supply to low levels in or below the sediments would arrive in a pulsating manner.

In view of the factors discussed above, we may expect that basalts near the top of the basement in most abyssal areas will ultimately be subjected to oxidative alteration. Accordingly, we can conceptually anticipate the following sequence of alteration events. Near-surface portions of newly erupted basalts will be subject to alteration by oxygenated bottom waters immediately following eruption. The interior portions immediately enter a regime of nonoxidative "diagenesis," and, following burial by sediments or later flows, the entire flow undergoes nonoxidative diagenesis until the diffusional influx of a new supply of oxygen from overlying bottom waters. In most abyssal areas the rate of sedimentation is so low and the retardation of oxygen supply so inefficient that nearsurface parts of cooling units, even after burial, never enter a nonoxidative regime. Interior parts of flows (more than a few centimeters from a surface), on the other hand, will undergo nonoxidative diagenesis followed by oxidative diagenesis, and the nearer the rock mass to an original cooling surface or to a primary or secondary fracture, the sooner the oxidative front arrives.

These conceptual anticipations were inferred by Bass et al. (1973a; see especially p. 491-492), but could not be wholly confirmed because of the inadequate samples available and because, in the best example available for study (from Hole 170), the oxidative front had already penetrated below the level of the bottom of the hole and a transition of conditions could not be seen. Those transitions are clearly visible in the coarser grained, more massive cooling units from Hole 319A and Site 321, and the alteration under the two regimes can now be described in detail.

\section{NONOXIDATIVE DIAGENESIS}

Rocks which have undergone only nonoxidative diagenesis are medium to dark gray and hard. There is an inadvertent tendency to call them fresh at first glance, but the abundant veins in jointed rocks, the smectite mesostases seen in thin sections, and the water and $\mathrm{K}$ contents soon correct this notion. Furthermore, it is strictly inaccurate to call this diagenesis "nonoxidative" inasmuch as there is evidence, as given below, that significant oxidation occurs. The least-fractured cores recovered during Leg 34 are Core 3, Sections 3 and 4, from Hole 319A. The ferric Fe in those cores, despite their being "nonoxidatively" altered, constitutes less than $10 \%$ of the total $\mathrm{Fe}$ on an atomic basis (Rhodes et al., this volume), and the $\mathrm{Fe}$ is thus as reduced as that in the freshest, least-altered basalts ever recovered from the crests of spreading ridges. Those cores probably retain an oxidation state closely approximating that of the magma at the time of eruption. The other "nonoxidatively" altered rocks from Hole 319A and the other Leg 34 holes contain Fe that is considerably more oxidized, but variably so, probably as a result of proximity to joints and other avenues of rapid diffusion and hydrodynamic flow. The nature and timing of the oxidation remain a problem because sulfides formed contemporaneously with ferric Fe-rich smectite and celadonite during the "nonoxidative" diagenesis. The uniform appearance of these rocks probably stems from the fact that the kinetics of oxidation of iron and of crystallization of smectite and other secondary Fe-bearing phases, plus the stability relations of those phases, are such that the ferric iron can be incorporated into them without producing effects which are visible macroscopically or microscopically, but only by chemical analysis. When the abundance of ferric iron exceeds the stable carrying capacity of the secondary phases, or the rate of oxidation is too fast relative to the rate of crystallization to allow incorporation of the ferric $\mathrm{Fe}$ in the new phases, then predominantly ferric $\mathrm{Fe}$ phases precipitate and the effects are easily visible. In the latter case, the rocks are classified as oxidatively altered, and in the former as nonoxidatively altered, but it must be understood that "nonoxidative" is in a relative sense only. With this caveat, and without any implication that the causes and progress of nonoxidative alteration are fully understood, a description of the nonoxidative effects follows.

\section{NONOXIDATIVE DIAGENESIS OF PRIMARY PHASES}

The golden yellow smectite and fibropalagonite that replace interstitial glass and olivine, which were described above under seawater alteration, could just as logically have been described in this section. They typify the outer few centimeters of joint blocks, or about 10 to $15 \mathrm{~cm}$, at most, of the boundaries of flows. Further inward the rocks are coarser grained and the interstitial 
altered glass more abundant. The coarsest grained rocks from Hole 319A and Site 321 are richest in interstitial mesostasis and it is in them that the products of nonoxidative alteration are best seen.

Among the phenocrysts and primary minerals from the main stage of crystallization only olivine is significantly affected. It is most commonly altered to relatively coarsely crystalline blue or blue-green smectite, as seen in hand specimen (green or brownish-green in thin section), with prominently developed mesh texture in the larger and some smaller grains, recording the cracks along which the alteration first progressed. In drilling and sawing, the smectite swells and the pseudomorphs and partially altered olivines tend to pluck and wash out, leaving dark holes on the surfaces of cores, and holes of unclear origin in thin sections. The absence of cracks and other evidence of stresses resulting from swelling of smectite in the cores, even near veins with voids where expansion could have occurred with little resistance, indicate that the smectites were nearly in exchange equilibrium with the fluids to which they were exposed throughout their burial history. These fluids were initially connate seawater. In locally closed systems they may have become more concentrated than seawater during reactions with wall rocks and the consumption of water in secondary minerals. Near cracks opened later, the fluids may once again have approached the composition of seawater or the interstitial waters of overlying sediments. At no time, however, do the fluids appear to have been fresh or significantly less concentrated than seawater, or else the higher activity of water in the fluids would have caused swelling like that seen on shipboard. (This observation is generally true for smectites formed at any stage in the history of the basalts. Freshly exposed smectite linings of partially filled vugs and vesicles are never, to the writer's knowledge, cracked or spalled loose into the hole. On drying, cracks appear, and, with rewetting and further drying, spalling occurs. Dilute solutions in nature could have produced similar effects.)

$\mathrm{X}$-ray analysis of a composite sample of pseudomorphs after olivine phenocrysts and partially altered phenocrysts, from which the remnant fresh olivine was removed (Hole 319A, Core 3, many depths; see Table 2), reveals minor talc and a possible trace of mica (probably celadonite) in addition to the smectite. Both the talc and smectite are more silica saturated than olivine and require an outside source of silica. The smectite also required addition of $\mathrm{A} 1$. The observed deuteric minerals (see above) do not suggest a deuteric source for the silica (although Bunch and LaBorde, this volume, report interstitial quartz in one rock). Thus, the talc is more likely a diagenetic product formed during nonoxidative diagenesis like the smectite and talc in veins assigned to this stage of alteration (see below). The silica may have been freed from altered glass or from the fayalite component of the olivine when Fe went to form an oxide or hydrated oxide of some sort, or else $\mathrm{Mg}$ was lost during alteration of the olivine. In general, $\mathrm{Si}$ supply will be seen to be a limiting factor in the origin of diagenetic minerals during both nonoxidative and oxidative diagenesis. The celadonite tentatively identified in the pseudomorphs after olivine implies addition of K. Cela- donite is a ferric Fe- and silica-rich mineral which, as developed later, can form during oxidative or nonoxidative diagenesis. The altered olivine from Hole 319A, Core 3, was selected from nonoxidatively altered rocks; thus, the celadonite, if present, is of nonoxidative origin in this case and implies that mobile $\mathrm{K}$ from some unknown source, possibly outside the basalt, can reach the basalt and become fixed in $\mathrm{K}$-rich phases before visible effects of oxidation appear.

Many of the blue smectite pseudomorphs after olivine contain tiny patches of carbonate (mineralogy uncertain). In some instances the pseudomorphs of large groundmass olivines are largely or wholly carbonate, and these may characterize local areas of given thin sections to the exclusion of smectite pseudomorphs (e.g., 319-13-1, 103-107 cm). Carbonate in pseudomorphs after olivine seems to characterize thin cooling units and the contacts of thicker ones, which is consistent with assignment of the carbonate to a diagenetic rather than deuteric stage of alteration. The carbonate, like fresh olivine, and the earthy $\mathrm{Fe}$ oxide and smectite pseudomorphs after olivine, tend to pluck during grinding of thin sections, and the presence of otherwise unexplained holes in such sections should give cause to look more carefully for olivine or its alteration products. Primary olivine in both fresh and altered rocks has no doubt often been underestimated for this reason.

The other primary minerals (plagioclase, clinopyroxene, and titanomagnetite) were not visibly altered during nonoxidative diagenesis of the Leg 34 rocks. Clinopyroxene and, to a lesser extent, plagioclase are altered in some of the Cretaceous igneous rocks cored during Leg 17 (Bass et al., 1973a, b), so these phases are not necessarily stable, but may simply react too slowly to show significant alteration after $40 \mathrm{~m} . \mathrm{y}$. or less. However, all of the Leg 17 rocks in which such alteration was observed had undergone oxidative as well as nonoxidative diagenesis, and the alteration, of clinopyroxene, at least, may require intense oxidation.

The phases formed during the last stages of primary cooling of the coarse-grained rocks included skeletal plagioclase and opaque minerals (mainly titanomagnetite, at most minor ilmenite), purple titanaugite, rare pigeonite, and either glass or quench smectite. Whereas total rock X-ray patterns of quenched rocks do not include recognizable titanomagnetite peaks, they are present and often prominent in the patterns of coarsegrained rocks and the abundance of titanomagnetite appears to increase with that of interstitial smectite (Tables 2 and 4, total rocks). This increase of latecrystallizing opaque minerals has been noted in other papers in this volume on the petrography of the Leg 34 basalts. The variations cannot be attributed to change of bulk chemistry. The bulk rock analyses of various samples from a given thick cooling unit, including the thickest two from Hole $319 \mathrm{~A}$ and the unit comprising the bulk of recovered rocks from Site 321 (other papers, this volume), do not show notable variations in total $\mathrm{Fe}$, even in the coarsest grained rocks, and the atomic ratio total $\mathrm{Fe} /($ total $\mathrm{Fe}+\mathrm{Mg}$ ) does not show significant variation within those cooling units, even the thickest ones. For instance, the total range of $\mathrm{Fe} /(\mathrm{Fe}+\mathrm{Mg})$ 
(atomic) in the 15.6-meter unit in Hole $319 \mathrm{~A}$ is 0.469 to 0.574 , with only 5 out of 20 values above 0.5 , and these 5 showing no systematic variation with depth; in the 12.5 meter unit from Hole 319A the range is 0.456 to 0.483 (4 values); and in the thick unit from Site 321 it is 0.500 to 0.603 (18 values), again with no systematic variation with depth. (These indications of the absence of significant internal differentiation are consistent with textural and mineral-chemical indications of rapid cooling.) Thus, the cause of the increase in opaque minerals must be sought in local crystallization differentiation. The highly fractionated, late, hydrous liquids must have been rich in iron and probably had higher $\mathrm{Fe}^{+3} / \mathrm{Fe}^{+2}$ than the original magma, and both of these factors undoubtedly contributed to the increased amounts of opaque minerals in the coarser grained rocks. Under sufficiently oxidizing conditions, they gave rise to an opaque assemblage which included a relatively low-Ti titanomagnetite plus ilmenite. It is in the coarser grained rocks also that the high activity of water in the late liquids led locally to crystallization of biotite.

Among these late interstitial phases the iron-rich minerals (biotite and titanomagnetite) and any glass which formed by quenching were especially susceptible to later oxidation and hydration reactions, during both the deuteric and diagenetic stages. As noted above, biotite may be largely altered, probably to smectite; the alteration may have occurred during the deuteric or nonoxidative diagenetic stage. The magnetite may have been deuterically oxidized to some extent, but was probably stable during nonoxidative diagenesis like the earlier-formed titanomagnetite. If quench glass was present, its conversion to the green or brownish-green smectite mass now occupying the interstices probably occurred early during nonoxidative diagenesis.

In the interstitial smectite of the coarser grained rocks there are tiny crystals or clusters of colorless material of low refringence and birefringence. It is not epoxy. The vague suggestion of a crudely radial structure in rare cases originally suggested to the writer that the minerals might include phillipsite. Bunch and LaBorde (this volume) report nearly stoichiometric $\mathrm{K}$-feldspar in the groundmasses of some coarser grained rocks. If so, the minerals observed by the writer may be largely or wholly $\mathrm{K}$-feldspar, and indeed he found a possible X-ray peak of $\mathrm{K}$-feldspar in the total-rock diffraction pattern of Sample 321-14-3, $100 \mathrm{~cm}$ (Table 4). If it is primary, it would represent extreme fractionation exceeding even the remarkable fractionation reported in lunar rocks. However, primary alkali feldspar would be expected to be a mixed $\mathrm{Na}-\mathrm{K}$-feldspar, and, in any case, it is unlikely to form in a hydrous, Fe-rich liquid after biotite had begun to crystallize, unless there were a release of pressure and effective reduction of water pressure, which is unlikely in these submarine rocks, or unless the $\mathrm{K}$-feldspar is part of the deuteric breakdown products of biotite, which seems unlikely for the rocks in question. If $\mathrm{K}$-feldspar is present, its stoichiometric composition is consistent with a diagenetic origin. But that explanation poses problems no less difficult than those of a primary origin. As Bass et al. (1973a) describe, diagenetic Kfeldspar, where definitely found, occurs only as a replacement of the cores of large, relatively calcic plagioclase grains, not in groundmasses where late plagioclase, if present at all, is likely to be sodic. Furthermore, they point out (1973, p. 493-494) that the formation of $\mathrm{K}$-feldspar proceeds only after any extant smectite is saturated with $\mathrm{K}$ ions relative to the ambient interstitial fluids. In the $\mathrm{K}$-poor, smectite-rich, coarsegrained rocks from Leg 34 the smectite is unlikely to be saturated with $\mathrm{K}$. Thus, the K-feldspar remains a mystery and deserves confirmation and, like the identities of the colorless groundmass grains, further study.

\section{VEINS AND AMYGDULES FORMED DURING NONOXIDATIVE DIAGENESIS}

Veins formed during nonoxidative diagenesis are among the most prominent features of the rocks from Leg 34, especially the thick cooling unit from Site 321. They are composed mainly of green to blue-green smectite, carbonate, mica, and sulfide in various combinations. Other minor phases are revealed by X-ray analysis. Amygdules contain essentially the same phases, but commonly in different proportions. The amygdules formed by infilling of vesicles. The history of the veins is not quite so obvious; they are largely voidfree, but uncommon vugs are present. The presence of wall-rock spalls in the veins and lack of evidence for replacement of wall rocks confirm the conclusion that the veins represent fillings of once open cracks. Either the filling occurred as fast as the cracks were opened, or the time of vein-mineral deposition since opening of the cracks was very long. The contemporaneous deposition of veins and amygdules is readily seen where a vein of smectite or sulfide is contiguous with an identical filling of a vesicle. The implied sequence is: vesicle; crack; vein. Further details are brought out in the following separate descriptions of the minerals.

\section{Smectite}

This, the most abundant vein mineral, is commonly dark green or medium to light blue-green, or rarely dark gray or brownish-gray. The colors are stable on exposure to air, in contrast to blue smectites from Butte, Montana, which rapidly change color due to oxidation on exposure to air (J.J. Hemley, personal communication, 1973). A chemical analysis of a dark green smectite is given in Table 5. It is one of the two smectites which gave $\delta \mathrm{O}^{18}=24.8$ (Muehlenbachs, this volume), indicating low temperature formation in isotopic equilibrium with seawater or an isotopically similar connate water. The smectite separate contained $5 \%$ or less of chlorite, about $2 \%$ plagioclase (as estimated from Xray peak heights), and minor random-mixed-layer chlorite-smectite. The low $\mathrm{C} 1$ indicates that seawater salt is insignificant. The analysis was corrected by assuming that all $\mathrm{CaO}$ is part of plagioclase (estimated composition $\mathrm{An}_{55}$, which gives a total plagioclase correction of $2.37 \%$ by weight), and simply ignoring $\mathrm{P}_{2} \mathrm{O}_{5}$, an assumption not wholly defensible since all the $\mathrm{CaO}$ present would be needed to account for the $\mathrm{P}_{2} \mathrm{O}_{5}$ as apatite. The structural formula, calculated according to 
TABLE 5

Wet Chemical Analysis ${ }^{\text {a }}$ of

Green Smectite Formed During

Nonoxidative Diagenesis,

Sample 321-14-3, 80-100 cm

\begin{tabular}{lcc}
\hline & $\begin{array}{c}\text { Original } \\
(\%)\end{array}$ & $\begin{array}{c}\text { Corrected }^{\mathrm{b}} \\
(\%)\end{array}$ \\
\hline $\mathrm{SiO}_{2}$ & $42.60 \%$ & $42.33 \%$ \\
$\mathrm{TiO}_{2}$ & 1.01 & 1.04 \\
$\mathrm{Al}_{2} \mathrm{O}_{3}$ & 6.57 & 6.03 \\
$\mathrm{Fe}_{2} \mathrm{O}_{3}$ & 8.93 & 9.15 \\
$\mathrm{FeO}$ & 4.51 & 4.62 \\
$\mathrm{MnO}$ & 0.03 & 0.03 \\
$\mathrm{MgO}$ & 16.70 & 17.11 \\
$\mathrm{CaO}$ & 0.27 & 0.00 \\
$\mathrm{Na}_{2} \mathrm{O}$ & 1.27 & 1.18 \\
$\mathrm{~K}_{2} \mathrm{O}$ & 0.76 & 0.78 \\
$\mathrm{H}_{2} \mathrm{O}+$ & 6.81 & 6.98 \\
$\mathrm{H}_{2} \mathrm{O}-$ & 10.29 & 10.55 \\
$\mathrm{P}_{2} \mathrm{O}_{5}$ & 0.20 & 0.20 \\
$\mathrm{Total}$ & 99.95 & 100.00 \\
$\mathrm{C} 172$ ppm & \\
\hline
\end{tabular}

${ }^{\mathrm{a}} \mathrm{H}$. Onuki, Analyst.

$\mathrm{b}_{2.37 \%}$ plagioclase (An55) sub-

tracted, normalized to $100 \%$.

Ross and Hendricks (1945, p. 41-43) and ignoring $\mathrm{TiO}_{2}$, is:

$$
\begin{aligned}
& \mathrm{X}_{0.33}\left(\mathrm{Fe}^{+3}{ }_{0.52} \mathrm{Fe}^{+2}{ }_{0.31} \mathrm{Mg}_{2.05}\right) \\
& \left(\mathrm{Fe}^{+3}{ }_{0.03} \mathrm{Al}_{0.57} \mathrm{Si}_{3.40}\right) \mathrm{O}_{10}(\mathrm{OH})_{2}
\end{aligned}
$$

In this calculation the exchangeable equivalents are assumed to be 0.33 , a value typical of smectites. However, the exchangeable equivalents represented by the $\mathrm{Na}$ and $\mathrm{K}$ in the analysis, and corresponding to the above structural formula, amount to only 0.26 . Assuming the smectite is typical, and aside from possible analytical errors, the deficiency of exchangeable cations in part is ascribable to the chlorite impurity and in part may be due to an improper correction for plagioclase (for instance, assignment of some $\mathrm{CaO}$ to apatite and reduction of the amount of plagioclase removed would increase the remaining $\mathrm{Na}$ ). A presently nonassessable explanation, which was discussed by Bass et al. (1973a, p. 436-437), is that $\mathrm{Mg}$ may occupy exchangeable sites in smectites formed in nonporous, impermeable media in which the amount of available seawater $\mathrm{Na}$ is limited. All in all, however, the analysis and formula are reasonable for a smectite. It is almost trioctahedral ( 2.89 octahedral cations), which agrees with $(060) d$-values which are usually about $1.53 \AA$ in the green Leg 34 smectites, and is largely a saponite with minor nontronite and ferrosaponite components. Note the presence of some tetrahedral ferric Fe. The writer has found such tetrahedral $\mathrm{Fe}$ in other analyzed oceanic smectites, which will be described elsewhere.

A surprising result is the high ferric $\mathrm{Fe}$ content of the smectite, which is the most abundant phase formed dur- ing nonoxidative diagenesis and was expected to contain largely ferrous Fe. An analysis of a similar Leg $34 \mathrm{smec}-$ tite by Seyfried et al. (this volume) is similarly rich in ferric Fe. It is said to contain essential $\mathrm{CaO}$, and no impurity was cited to explain its presence, though a relatively low $\delta \mathrm{O}^{18}$ suggests that deuteric or primary mineral impurities may be present. The ferric Fe in these smectites explains the stability of the smectite on exposure to air. If the interstitial smectites in the groundmasses of the host basalts of the veins are similarly rich in ferric $\mathrm{Fe}$, they account for the highly oxidized $\mathrm{Fe}$ found in most analyses of Leg 34 rocks, and it is the oxygen to produce such $\mathrm{Fe}$ in the nonoxidatively altered rocks that poses an as yet unsolved problem.

The green smectites are abundant and well crystallized in the interiors of cooling units. Toward the surfaces they decrease rapidly in abundance and are typically absent or very minor near the surface (at least insofar as X-ray determinations are concerned). However, an intense oxidative overprint in near-surface rocks obscures any earlier nonoxidative minerals if they were ever present, and, as discussed under oxygen supply above, the very near-surface rocks may never haveundergone nonoxidative diagenesis. Such being the case, it can be argued that the constituents of the vein smectites did not come from external sources, such as basalts at greater depths undergoing intense diagenesis or metamorphism. Rather, most of them are from the immediate host rock. One partial exception may be $\mathrm{K}$ which seems to have been added both to veins and host rocks from an external source, probably seawater and connate pore waters. Some $\mathrm{Na}$ may similarly have been added.

An important point to be made in this respect is that both the analyzed smectite above and other oceanic smectites studied by the writer, while they are low in Al, nonetheless contain significant $\mathrm{Al}$. If the $\mathrm{Al}$ is from the host rock, as seems likely, then $\mathrm{Al}$ is mobile to a significant extent and cannot serve as an absolute basis for normalization in mass balance calculations. It is not yet clear whether $\mathrm{TiO}_{2}$ is similarly suspect. The best normalization reference may, in the last analysis, be oxygen, which controls a quasiconstant volume framework through which the mobile cations move.

\section{Chlorite and Random-Mixed-Layer Chlorite-Smectite}

The smectite and random-mixed-layer (RML) chlorite-smectite which replace deuteric chlorite (see above) probably formed during nonoxidative diagenesis. That chlorite, the abundance of which is comparable to or much greater than that of accompanying smectite, is distinct from a second type of chlorite which is invariably much less abundant than the associated vein smectite (such as the chlorite impurity in the analyzed smectite; see above). This second type of chlorite, which is ascribed to the nonoxidative stage of diagenesis, was found only by $\mathrm{X}$-ray analysis in samples from Hole 319A and Site 321 where it occurs both in thin, fine-grained, and in thick, relatively coarse-grained cooling units. In the thin units and near the boundaries of thick units the veins are oxidized brown or tan. Otherwise they are green, blue-green, or gray. The rare RML chlorite-smectite associated with the diagenetic 
chlorite is found only in green or blue-green veins in the interiors of thick cooling units.

The diagenetic origin of the chlorite (and RML chlorite-smectite) was confirmed by X-ray analysis of selected portions of thick, zoned veins in Site 321 basalts. They are dominantly dark green, gray-green, or gray smectite which sharply or gradationally gives way centrally to patches or a continuous zone of medium grayish-blue smectite. Central cavities, where present, are lined by striking light blue or blue-green smectite which rarely occur as druses of randomly stacked rodshaped crystals. The most notable example is $321-14-3$, $80-100 \mathrm{~cm}$. Light blue smectite from its center and from the centers of veins from 321-14-2, 74-150 cm have more chlorite than the dark outer smectite zones forming the bulks of the veins, in which chlorite was not detected. A concentration of light blue botryoidal smectite from a vein in $321-14-3,126-130 \mathrm{~cm}$ has relatively greater amounts of chlorite than the dark gray smectite vein in $321-14-3,120-124 \mathrm{~cm}$. The structures of the veins suggest one continuous period of filling rather than an early dark green vein which was later reopened to allow deposition of the bluer centers. There is no suggestion that chlorite replaced smectite or vice versa, though such evidence is not readily seen since the chlorite is not macroscopically visible and the veins were not sectioned. Thus, unless one postulates rising temperature during vein deposition, for which there is no other mineralogical, textural, or isotopic evidence (however, see Field et al., this volume, and the discussion of marcasite and pyrite below), and which is a priori unlikely, he must conclude that all vein components formed under closely similar conditions, and, hence, that, if the smectite formed during low-temperature diagenesis, so did the chlorite and associated RML chlorite-smectite.

Smectite amygdules with color zonations as in the veins described above show no chlorite at all, much less a variation in chlorite abundance in the various zones. Either the amygdules formed under different conditions or they were completely filled before conditions conducive to precipitation of diagenetic chlorite arose.

\section{Talc}

Trace to minor amounts of talc occur in rocks from Holes 319A and 320B and Site 321. It is invariably associated with smectite. Beyond this its associations are varied. It is found in pseudomorphs after olivine (nonoxidative in Core 319A-3; oxidative in Cores 319A$3,-4$, and -5 ; see Table 2); in a diktytaxitic vug where it may be pneumatolytic or hydrothermal (319A-1-1, 137 $\mathrm{cm}$ ); with deuteric chlorite; in diagenetic smectite veins (nonoxidative except for one vein, 319A-1-1, 29-31 cm); and in smectite plus mica veins (Site 321 only). In the diagenetic smectite veins the talc is associated with chlorite in all except one sample (321-14-2, $83 \mathrm{~cm})$. It is associated in a majority of samples with calcite, but in only one (319A-2-1, 108-110 cm) with aragonite. In Hole $319 \mathrm{~A}$ it shows no correlation with mica, whereas at Site 321 it coexists with mica in two of three samples where the mica does not coexist with goethite (which suggests that both mica and talc are of nonoxidative diagenetic origin). In Hole 319A the talc tends to favor thin cooling units or the boundaries of thick ones, in part reflecting its coexistence with deuteric chlorite, which shows a similar tendency. In Site 321 basalt the talc occurs in the interior of the thick cooling unit.

From these various correlations it is concluded that the talc is both deuteric and diagenetic in origin, and that the diagenetic talc, while not necessarily sensitive to redox potential, formed under nonoxidative conditions. Talc probably formed locally where silica activity was fairly high. This is also reflected in the mica, which is probably a high-silica, dioctahedral, ferric $\mathrm{Fe}$ mica (celadonite). While the mineral associations in veins and amygdules probably do not represent strictly equilibrium associations, in most, or even all, cases there are nonetheless enough components that are less than perfectly mobile ( $\mathrm{Si}, \mathrm{Al}, \mathrm{Fe}^{+3}, \mathrm{Fe}^{+2}, \mathrm{Mg}$ ) to account for an equilibrium assemblage of smectite, chlorite, talc, and celadonite, if such an assemblage should occur, in accord with the mineralogical phase rule.

\section{Calcite and Aragonite}

Calcite associated with green smectite, sulfides, and aragonite has a high $\mathbf{M g}$ content and presumably formed during nonoxidative diagenesis according to arguments to be developed in a later section. It occurs in both veins and amygdules. In veins it may be abundant, scarce, or sporadic and lenticular; it is granular, and is never vuggy where associated with green smectite, hence was not the terminal constituent of nonoxidative diagenetic veins. In amygdules it varies in abundance, but tends to be either scarce (or absent) or the dominant phase. Dominantly calcite amygdules are prominent in the thick unit at Site 321, and they have a radial internal structure.

Aragonite was found only in Holes 319 and 319A. While it may prove to be common, the only other occurrence of aragonite in DSDP basalts known to the writer was found in vugs and veins in some of the basalts cored during Leg 37 (C.E. Appleman, personal communication, 1974). In the Leg 34 basalts it was confirmed by X-ray analysis only in veins. While it was not found by X-ray analysis in vugs and vesicles, irregular aggregates of aragonite were seen in thin section in Sample 319-13-1, 103-107 cm, and associated carbonate pseudomorphs after olivine may be aragonite. In the great majority of cases where the aragonite is associated with smectite, it is green or gray; where it is dominantly yellow or brown (oxidized), there are nearby remnants of green smectite which indicate that the original assemblage included green, unoxidized smectite. It is thus concluded that the aragonite formed exclusively during nonoxidative diagenesis and did not invert to calcite as fast as smectite was oxidized during oxidative diagenesis.

Some of the aragonite is granular. The most striking textures, however, are stellate arrays of prisms seen on the surfaces of joints when they are opened. The freshly exposed arrays may have no matrix between the prisms, which suggests that the prisms grew into open voids, some of which were still open when the basalt was cored. While the observed configuration may be a mechanical artifact of opening the joint in the lab, there is other, more suggestive evidence in the form of noncarbonate interprism fillings. Thus, a stellate array is embedded in 
brown birnessite in $319 \mathrm{~A}-2-3,38-43 \mathrm{~cm}$, and prismatic molds in birnessite in 319A-7-1, 88-93 cm, probably once held similar prisms. The arrays seem to have grown in voids later filled by birnessite. Thus, aragonite seems to have grown directly from solution, as opposed to replacing some previous mineral, and we evidently have observed the actual surfaces of aragonite crystals as they existed when growth ceased. Accepting this argument, it is then pertinent to observe that the crystal surfaces of both prismatic and granular aragonite are clean, smooth, and vitreous. They show no signs of solution, etching, overgrowth, or the microcrack-induced opacity that commonly accompanies inversion to another phase of significantly different molar volume. We may thus conclude that aragonite, like the green smectite, was in equilibrium (or metastable equilibrium) with the fluids from which it grew.

The interpretation of these observations will be given in a later section on carbonates after discussion of those formed during oxidative diagenesis. For the moment we need note only one conclusion, namely the absence of aragonite in rocks older than Miocene among the Leg 34 basalts. The only other case of aragonite in basalt which the writer has found is in amygdules in basalts dredged from small seamounts on top of Coiba Ridge in the Gulf of Panama. The rocks underlying the ridge could be as old as Oligocene or conceivably Eocene. The seamounts are the same age or younger. The Coiba Ridge aragonite occurs as stout prisms radiating from points on the walls of large vesicles. The ends of the prisms are inverted to white, opaque calcite, and the remainders of the vesicles are filled with green smectite (where unoxidized). From these restricted occurrences it is inferred that in oceanic crustal basalts older than Miocene or Oligocene the aragonite has inverted to calcite or been dissolved and replaced by calcite or magnesian calcite.

In Holes 319 and 319A the calcite and aragonite commonly coexist. Where one occurs without the other, it is more often calcite than aragonite. They occur in both thin and thick cooling units, and within the thick units in both the interior and near-surface parts. Thus, carbonate deposition seems to have been controlled by conditions that were independent of the boundaries of cooling units and the occurrence of now carbonate-filled voids of various types and sizes related to those boundaries. This independence probably reflects an external, nonlocal source of carbonate and bicarbonate ions, presumably in the sediments above the basement (Bass et al., 1973a, b). On the other hand, there is a distinct diminution in thickness, length, and abundance of carbonate veins toward the very surfaces of flows (or sills) and pillows, which suggests that the $\mathrm{Ca}$ and $\mathrm{Mg}$ were derived internally. Thus, while it is clear from interpillow carbonate fillings and carbonate cements in hyaloclastites between cooling units in many DSDP holes (e.g., Leg 17, Hole 166) and in uplifted and exposed volcanic sections presumed to be old oceanic crust that some loss of $\mathrm{Ca}$ and $\mathrm{Mg}$ occurs, it may well be that, to a first approximation, such losses are generally minor and the mobile cations were not lost from their parent bodies. The same paucity of near-surface veins was observed in regard to smectite veins also (see above). Since carbonate and smectite are the main vein and amygdule constituents, it appears that, though the bulk chemistry of the igneous body may be locally disturbed, the body as a whole retains almost its original nonvolatile chemistry (i.e., except for addition of $\mathrm{H}_{2} \mathrm{O}, \mathrm{CO}_{2}$, and $\mathrm{K}$, and oxidation of $\mathrm{Fe}$ ). Thus, an average vertical section through a flow or sill, including veins and amygdules, should give the original bulk chemistry.

\section{Pyrite and Marcasite}

These sulfides were found in the basalts from Hole $319 \mathrm{~A}$ and Site 321 where they occur exclusively in the interiors of thick cooling units, either alone or in association with green smectite, calcite, aragonite, chlorite, mica, and talc. Where the sulfides are the sole constituents of veins, the veins locally form complexly anastomosing systems. Both simple and anastomosing veins of pure sulfide tend to be lenticular, typically not extending as far as associated carbonate- and smectiterich veins. Like them, the sulfide veins are contiguous with amygdules of the same composition where they intersect former vesicles. The general relations imply vein formation by filling of cracks opened in cold, brittle rocks after vesicle formation. Some sulfide amygdules near veins have no visible connections to the veins, implying great sulfide mobility.

Pyrite has been frequently reported from DSDP and other submarine basalts. The writer is not aware of reports of marcasite in them prior to this volume (Scott and Swanson, this volume, also report marcasite). In Hole 319A and at Site 321 they invariably coexist in sulfide-bearing veins in which the existence of marcasite was first suspected from the light whitish-yellow color of part of the sulfide. Sulfides in vesicles yield X-ray peaks of pyrite alone, perhaps due to the small amounts of available material and consequently weak peaks, though there were no color indications of marcasite either. On rechecking the $\mathrm{X}$-ray patterns of sulfides from the Cretaceous igneous rocks cored during Leg 17, the writer could find no indication of marcasite. One might tentatively conclude that marcasite in oceanic crustal rocks older than some time predating the late Eocene will have inverted to the stabler form pyrite. However, all Leg 17 rocks were oxidatively altered, and sulfides in them were scarce and minor in amount where found, so this statement concerning the kinetics of marcasite inversion has not been exhaustively tested and must be regarded as tentative.

The two main problems posed by the sulfides are the coexistence of two forms of $\mathrm{FeS}_{2}$ and the origin of the sulfur. These problems are treated in turn.

The coexistence of pyrite and marcasite has long been known. Buerger (1934) carefully analyzed the best available chemical data and suggested that pyrite is near pure $\mathrm{FeS}_{2}$, whereas marcasite is relatively slightly deficient in sulfur; therefore the problem is one of the coexistence of two compounds rather than a dimorphous pair. Kullerud (1967), reviewing high temperature experimental work on the problem, points out that the thermal inversion of marcasite fails to yield pyrrhotite in addition to pyrite, as predicated by Buerger's suggestion. Kullerud further points out that marcasite has never been synthesized in the pure Fe-S system, but has been produced in the Fe-As-S system. 
The suggested stabilization of marcasite by As could not be confirmed by analyses of natural marcasites. Marcasite has not been synthesized in the Fe-O-S system, but has been produced in the Fe-O-S-H system, suggesting that $\mathrm{H}-\mathrm{S}$ bonds may (meta-)stabilize marcasite.

In attempts at low temperature syntheses the most notable work is that of Allen et al. (1914) who report the simultaneous synthesis of pyrite and marcasite, with marcasite appearing only in acidic solutions and its proportion increasing with acidity and decrease of temperature. For the production of pure or almost pure marcasite (greater than 95\%), the required acidity decreases with falling temperature and is near neutrality at ordinary temperatures (Allen et al., 1914, p. 431). The problem posed in any attempt to apply these results to the Leg 34 occurrences is that they seem to require acid conditions, which are not hospitable to smectite formation or survival. One might postulate that the sulfides and smectite are not cogenetic, but that gratuitous solution would help little, if at all, since textures indicate that sulfides must postdate at least part of the smectite, which must then survive acid conditions. One can more reasonably appeal to the stabilization of smectite under acid conditions by sufficiently high metal cation to hydrogen ion ratios (see, for instance, Garrels and Christ, 1965 , p. $362-363$, fig. 10.7 , for such a situation with Na-montmorillonite). An intriguing possibility is to extrapolate the trends reported by Allen et al. (1914) to temperatures below "ordinary." The temperatures of the upper basalts at Sites 319 and 321 are below $10^{\circ} \mathrm{C}$ and might well be as low as $4^{\circ} \mathrm{C}$, in which case alkaline conditions might be suitable to the formation of both marcasite and smectite.

However, it is not possible to confirm or reproduce the results of Allen et al. They did not have the benefit of $\mathrm{X}$-rays to aid the identification of their products. Instead they used the Stokes method, a chemical technique based on the difference in susceptibility of sulfur in pyrite and marcasite to oxidation in ferric sulfate solution. Rosenthal (1956), in a later series of room-temperature experiments, with synthetic products identified by X-ray diffraction analysis, was unable to produce mixtures of pyrite and marcasite from aqueous solutions. Marcasite was formed exclusively from acidic solutions, pyrite from alkaline, and both precipitated directly, without an amorphous precursor. This is where the problem remains pending further field and laboratory data. As pointed out above, the deposition of the sulfur as sulfides during "nonoxidative" diagenesis poses a problem in itself in view of the evidence in the smectite, celadonite, and bulk rock analyses for oxidation of iron. We can tentatively resolve this problem by the kinetic postulate that oxidation of ferrous $\mathrm{Fe}$ is faster than that of sulfide so that, with a limited supply of oxygen compared to that of ferrous $\mathrm{Fe}$, the sulfur will be oxidized little or not at all. To the extent that it is oxidized, the resulting sulfate remains in solution and may even leave the system.

The origin of the sulfur is just as problematic as its state of oxidation and precipitation as marcasite. Field et al. (this volume), on the basis of the interpretation of $\delta \mathrm{S}^{34}$ values ranging from -24.2 to +23.0 as products of equilibrium fractionation, propose a hydrothermal model for the sulfides. The sulfur would presumably emanate from depth. There is no conclusive mineralogic or isotopic evidence for a hydrothermal origin of the sulfide-bearing veins, despite claims by Scott and Swanson (this volume) that some vein constituents are of hydrothermal origin, and it seems that one must entertain the possibility that the isotopic values are due to nonequilibrium processes. Seyfried et al. (this volume) get $\delta S^{34}$ values ranging from -27.53 to -30.14 , which are consistent with an origin similar to that of diagenetic sedimentary pyrite. This conclusion is compatible with the writer's observations on the sulfide-bearing veins, but does not solve the problem of the origin of the sulfur. One can find countless references to the reduction of marine sulfate. Commonly the stated or implied reducing agent is bacteria acting in sediments containing organic matter. In other cases, though, the agent is not clear, or an inorganic agent is not excluded, or is explicitly invoked, but, regrettably, the authors do not grace us with the identification of the inorganic agent. The Leg 34 basalts would be inhospitable hosts to hungry bacteria, all the more so in view of overlying columns of oxidized sediments, devoid of both organic matter in significant amount and visible sulfide, and without any direct suggestion of the former presence of sulfide. To invoke bacterial action to account for the vein sulfides is a nonenlightening gratuity better held in reserve.

Ade-Hall et al. (Petrography of Opaque Minerals, this volume) present modal data on sulfide minerals and show that the maximum concentrations in both veins and host basalts are comparable, thus allowing for the source of sulfur for vein sulfides in the host rock. Attractive though the suggestion is, there is no known agent which would mobilize the sulfur, and for which the activity gradient would be so steep that the sulfur would be redeposited millimeters or centimeters away. While it is true that oceanic basalts, including those cored during Leg 34, show wide variations in S content, the very low values are invariably correlated with unmistakable evidence for oxidative alteration (Bass et al., 1973a, p. 437, Table 7; Rhodes et al., this volume; Scott and Swanson, this volume) during which the sulfide was oxidized to soluble sulfate which remained dissolved in pore waters or left the basalt entirely.

The intriguing problem of the origin of the sulfur thus remains open, with many worn and standard suggestions, with none either compelling or alluring. Some important factor or datum has successfully eluded many inquiring minds.

\section{Mica (Celadonite), RML Mica-Smectite, and General Comments on Phyllosilicate Assemblages}

Mica was detected by X-ray diffraction analysis as a significant to major constituent in numerous green veins or their yellow or brown oxidized equivalents in basalts from Holes 319 and 319A, and Site 321. Where the abundance of the mica permits identification of the polymorph, it is $1 \mathrm{Md}$ in all cases except that in 321-14-1, $62 \mathrm{~cm}$, where it is a well-crystallized $1 \mathrm{M}$ type. The (060) 
peak indicates a dioctahedral structure. Similar micas from other DSDP sites are celadonites rich in ferric $\mathrm{Fe}$ and silica (Bass et al., 1973a, Leg 17, especially 170-16-1, 17-19 cm, Tables 1 and 2, p. 432-433, and discussion on p. 491-493; Kempe, 1974, Leg 26, p. 471-473; Seyfried et al., this volume; and Reid et al., Leg 6, unpublished analysis of amygdule from Hole 58 composed of celadonite which may be virtually free of ferrous Fe). It is reasonable to infer a similar composition for the vein micas under discussion. Trace amounts of mica occur with phillipsite in veins and vugs in basalts from Hole 320B; they are different in several respects from the micas in the other holes and are discussed below under oxidative diagenesis.

The associations of the celadonite are varied. At Site 321 it is invariably associated with smectite and may or may not be associated with calcite; in Hole 319A it may or may not be associated with smectite (smectite absent in two of five, or possibly seven, occurrences) and is never definitely associated with calcite (or aragonite); in Hole 319 the single occurrence is associated with calcite, but not smectite. At Site 321 it is always associated with chlorite, but only nonoxidative diagenetic chlorite, not deuteric; in Holes 319 and 319A it is never definitely associated with chlorite of either type. In none of the holes is it associated with RML chlorite-smectite. At Site 321 the celadonite never coexists with RML micasmectite; in Holes 319 and 319A it coexists with RML mica-smectite in four cases. Furthermore, the RML mica-smectite is never associated with chlorite or RML chlorite-smectite, and, in three of four samples where it coexists with celadonite, smectite is absent. At Site 321 the celadonite may or may not coexist with talc; in Hole 319A it never definitely coexists with talc. At Site 321 the celadonite definitely coexists with goethite in only one of six occurrences and in that one case smectite is also present; in Hole $319 \mathrm{~A}$ the celadonite coexists with goethite in two of five (possibly seven) occurrences, and those are the only two samples in which smectite does not coexist with the celadonite.

From these various associations it is inferred that celadonite is not deuteric but diagenetic, and may crystallize during oxidative or nonoxidative diagenesis. The celadonite formed during "nonoxidative" diagenesis is another of the phases containing the problematic ferric Fe formed during that stage. Presumably it precipitates directly from solution, as opposed to replacing an earlier phase, when $\mathrm{K}^{+}, \mathrm{Fe}^{+3}$, and dissolved silica are available. During nonoxidative diagenesis it competes for these ions with the other phyllosilicates (smectite, chlorite, talc), during oxidative diagenesis with phillipsite and goethite.

The regularities of the associations encourage an attempt to treat them in the manner of Peterson (1962) who found that the low-temperature, diagenetic claycarbonate associations in Mississippian limestones closely simulate stable or metastable assemblages which are well behaved and amenable to graphical representation in accord with the mineralogical phase rule (number of phases equals number of immobile components). The compositions of most Leg 34 phases are not known, and a simplifying selection of components among the numerous ones available $\left(\mathrm{SiO}_{2}, \mathrm{Al}_{2} \mathrm{O}_{3}\right.$,
$\mathrm{Fe}_{2} \mathrm{O}_{3}, \mathrm{FeO}, \mathrm{MgO}$ among relatively immobile components; $\mathrm{CO}_{2}, \mathrm{H}_{2} \mathrm{O}, \mathrm{O}_{2}, \mathrm{~K}_{2} \mathrm{O}, \mathrm{Na}_{2} \mathrm{O}, \mathrm{S}$ among the mobile ones; behavior of $\mathrm{CaO}$ uncertain) is not clear, hence the choice of projection is not readily made. Nonetheless, the writer feels it informative to give tentative conclusions that can be drawn if, for the moment, one assumes the uncomfortable position of regarding the RML phases chlorite-smectite and mica-smectite as thermodynamically meaningful phases. The most suitable two-dimensional projection, despite its serious limitations for present purposes, is the AKF diagram (Figure 5; molecular proportions).

The mica-bearing assemblages of basalts from Site 321 appear to have formed during nonoxidative diagenesis, which yielded the following assemblages: (1) smectite, (2) smectite-celadonite, (3) smectite-celadonite-chlorite, (4) smectite-celadonite-chlorite-talc, (5) smectite-chlorite, (6) smectite-chlorite-talc, (7) smectite-talc, (8) smectite chlorite-(RML chloritesmectite). All assemblages except (4) and (8) can be plotted in the AKF diagram. The compositional extent of chlorite is an estimate that is designed to facilitate

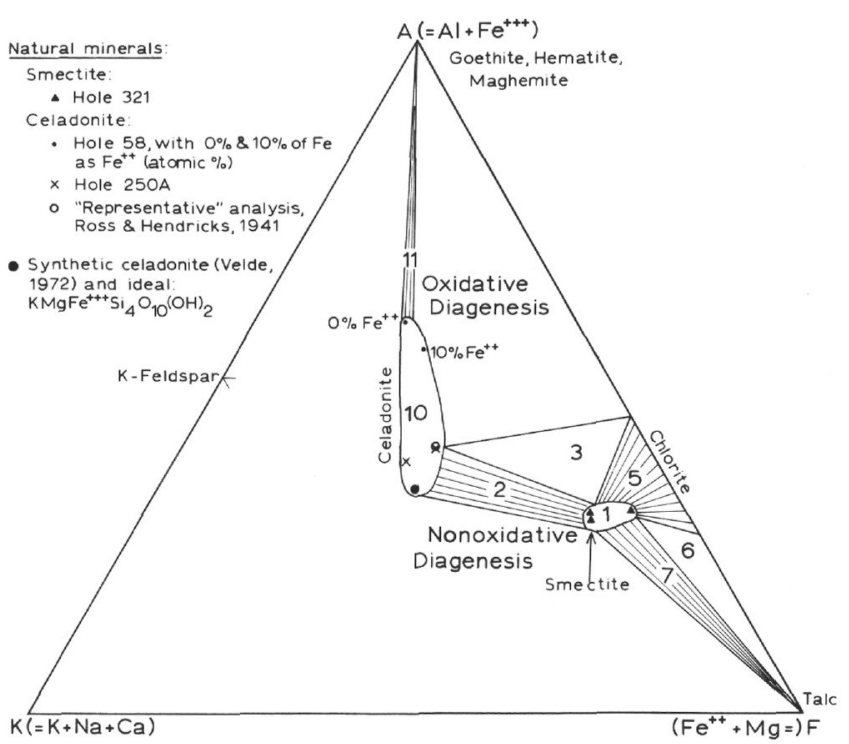

Figure 5. Modified AKF diagram (quartz generally absent) for diagenetic assemblages in oceanic crustal basalts. Hole 321 smectites are from this paper and Seyfried et al. (this volume). Nonoxidative diagenetic celadonites from Hole 250A, Leg 26, are from Kempe (1974). Oxidative diagenetic celadonite from Hole 58, Leg 6, is from Rhodes et al. (unpublished); the microprobe value for $\mathrm{Fe}$ in the mica is shown with atomic ratio $\mathrm{Fe}^{+2} /\left(\mathrm{Fe}^{+2}+\mathrm{Fe}^{+3}\right)=0$ and 0.1 . A better analytical total $(99.92 \%)$ results from $0 \% \mathrm{Fe}^{+2}$. The lower group of phase fields represents nonoxidative diagenesis, the upper group oxidative diagenesis. The topology of either group, taken alone, does not violate phase rule requirements for equilibrium. The rare 4-phase assemblages can be treated with similar consistency with equilibrium if one of the multiple components shown (such as $\mathrm{Fe}^{+2}$ and $\mathrm{Mg}$ ) is separated to give a 4-component space. The oxidation state of the phyllosilicates shown increases from the base toward the apex A (see text). 
drafting of the illustration. Assemblage 4, the only one with four phases, is either a nonequilibrium assemblage, or, more likely, requires more components than can be shown in a ternary diagram. There are numerous additional components to choose from since each component shown in Figure 5 is multiple. The separation of $\mathrm{Fe}^{+2}$ and $\mathrm{Mg}$ would readily create a four-component space in which assemblage 4 could be depicted. Granting the quasi-equilibrium nature of the observed assemblages, the goethite in vein 321-14-1, $125 \mathrm{~cm}$ (assemblage 3 ) must be a secondary product formed during oxidative diagenesis, while the remainder formed in mutual equilibrium during nonoxidative diagenesis. The RML chlorite-smectite of assemblage 8 never coexists with celadonite or talc. It could be treated as a singlephase compositional field with chlorite at one extreme, except that talc and celadonite, when associated with smectite, always coexist with the nonexpandable chlorite end of that hypothetical single-phase field rather than the smectite-rich end as demanded by normal phase chemical behavior. Either the RML chlorite-smectite is not a true thermodynamic phase, and should be ignored in the present treatment as a radically nonequilibrium complication, or it is "stabilized" by a constituent not equally essential in chlorite and smectite.

In Holes 319 and 319A we find, ignoring the deuteric chlorite-bearing assemblages (which include the only RML chlorite-smectite found in basalts from these holes), two groups of diagenetic assemblages numbered to correspond to the assemblages in basalts from Site 321:

Group I-(1) smectite, (2) smectite-celadonite, (9) smectite-celadonite-(RML mica-smectite), (5) smectitechlorite, (6) smectite-chlorite-talc (two of the four examples of this assemblage are deuteric), (7) smectite-talc (?-the only two occurrences of this assemblage are in pseudomorphs after olivine, and both present complications; in the red pseudomorphs, Hole 319A, Cores 3, 4, 5 , the talc peaks are so weak that its presence is uncertain; in the green pseudomorphs, Hole 319A, Core 3, a trace of mica may be present). The second group of assemblages is much more limited than the first.

Group II-(10) celadonite-(RML mica-smectite) (319-13-1, 68-72 cm); (11) celadonite-(RML micasmectite)-goethite (319A-3-5, 98-103 cm).

Group I corresponds to the diagenetic assemblages at Site 321 , with the difference that RML chlorite-smectite is absent and RML mica-smectite is present. Group I is ascribed to nonoxidative diagenesis, with any goethite present having been produced during the later superimposed oxidative diagenesis. When goethite-smectitebearing assemblages were placed in Group I, the criterion governing the assignment was the presence of remnants of green or greenish-yellow material which was taken to mean an originally green vein later discolored yellow, brown, or red by oxidation. By this criterion, all smectite-bearing assemblages are placed in Group I.

Group II, which is ascribed somewhat uncertainly to oxidative diagenesis during which goethite formed in equilibrium with celadonite, had three possible candidates dominated by the assemblage celadonite-(RML mica-smectite). Sample 319A-3-1, $55 \mathrm{~cm}$ was placed in Group I because of remnant greenish-yellow material, and its goethite is assigned a later, independent origin. Sample 319A-3-5, 98-103 cm is assigned to Group II because of the absence of any green coloration. Sample 319-13-1, 68-72 cm is assigned to Group II despite the absence of goethite and largely because of the absence of smectite. Ignoring the RML mica-smectite in assemblages (10) and (11) for reasons parallel to those given above for a similar treatment of RML chlorite-smectite, then (10) and (11) plot in a portion of the AKF diagram distinct from that in which assemblages interpreted as nonoxidative diagenetic plot. As Ross and Hendricks (1941) point out, natural celadonite contains essential ferrous $\mathrm{Fe}$, which implies relatively reducing conditions under which ferrous and ferric Fe coexist. The Leg 6 celadonite (Reid et al., unpublished) is very rich in ferric $\mathrm{Fe}$ and may contain no ferrous $\mathrm{Fe}$ at all. It necessitates a great extension of the field of celadonite toward the A corner of the AKF diagram because of the high ferric Fe content. Even if that celadonite is recalculated with $10 \%$ (atomic) of the $\mathrm{Fe}$ as ferrous, the field would still be greatly extended, as shown in Figure 5. The celadonite occurred as an amygdule in a highly vesicular lava that was emplaced at shallow depth or even subaerially on a former seamount or island in the Caroline group (it was among granules that were brought up on the bumper sub when Hole 58, which did not reach basement, was abandoned). Therefore, its highly oxidized condition is not anomalous. Thus, while Ross and Hendricks (1941) are probably right that essential ferrous $\mathrm{Fe}$ is present in natural celadonites, the range of conditions under which it is stable is so broad as to allow a greatly varying ratio of ferric to ferrous Fe. The celadonite analyzed by Kempe (1974) and the "representative" celadonite selected by Ross and Hendricks from among the analyzed examples available to them represent nonoxidative conditions. The Leg 6 amygdule represents oxidative conditions. Hence, despite the fact that all the assemblages can be portrayed without overlap on a single diagram, assemblages (10) and (11) represent a range of $\mathrm{fO}_{2}$ values much higher than the values represented by the remaining assemblages. This distinction is also reflected by progressive changes toward the A corner in oxidation indices of the various natural minerals portrayed in Figure 5.

\begin{tabular}{lcc}
\hline & $\begin{array}{c}\mathrm{Fe}^{+3} / \\
\left(\mathrm{Fe}^{+3}+\mathrm{Al}\right) \\
\text { (atomic) }\end{array}$ & $\begin{array}{c}\mathrm{Fe}^{+3} / \\
\left(\mathrm{Fe}^{+3}+\mathrm{Fe}^{+2}\right) \\
\text { (atomic) }\end{array}$ \\
\hline Smectites & $0.49-0.59$ & $0.64-0.69$ \\
Reduced celadonites & $0.58-0.63$ & 0.76 \\
Oxidized celadonite & $0.73-0.76$ & $0.90-1.0$ \\
Geothite, hematite, maghemite & 1.0 & 1.0 \\
\hline
\end{tabular}

In view of these facts, the absence of a chlorite-celadonite-goethite, a chlorite-celadonite and a goethitesmectite assemblage is not surprising and does not argue against the present treatment of the vein and amygdule assemblages as quasi-equilibrium assemblages.

There are differences between the nonoxidative diagenetic assemblages in Hole 319A and at Site 321, ex- 
emplified best perhaps by the types of RML phases (chloritic in Hole 321, micaceous in Hole 319A). The causes of the differences are not clear. The rocks from Hole 319A are richer in olivine and are OL-normative compared to the Q-normative rocks from Site 321 (see other papers, this volume), but it is unlikely that the constituents released during diagenetic alteration of primary phases were so different as to account for the contrasting aspects of the assemblages. The temperatures during diagenesis were probably not radically different. Time ( 40 m.y. at Site 321 versus 15 m.y. at Site 319) might account for the differences, but then one would expect such time-dependent features as addition of secondary constituents and inversion of unstable phases to be more advanced at Site 321. The absence of aragonite there meets this test, as does a slightly higher average $\mathrm{H}_{2} \mathrm{O}$ content in the basalts, but the much greater abundance of diagenetic mica at Site 319 is opposite to expectation. The main cause of the differences may thus be simply a greater supply of $\mathrm{K}$ in the pore fluids at Site 319. Alternatively, the assemblages may be controlled by the kinetics of nucleation and growth of many phases in a limited volume of solution, the composition of which continually changed as the various phases undergoing alteration and precipitation continually changed. If so, the present attempt to rationalize the assemblages in equilibrium terms is meaningless and the appearance of so few difficulties in this attempt is both misleading and surprising.

Let it again be emphasized that the interpretation of vein assemblages (10) and (11) in basalts from Site 319 as having formed during oxidative diagenesis is tentative. If the interpretation is wrong, then essentially no phyllosilicates formed during oxidative diagenesis. Even if it is correct, the phyllosilicate assemblages are notable for their restricted nature. Mica is the only phyllosilicate that appears to form at all readily under oxidizing conditions, as might be expected from its high content of ferric Fe. Pure smectite, talc, and chlorite do not form at all (smectite and chlorite are in fact altered or destroyed), and the only smectite that appears to form under oxidative conditions is the smectite component of RML mica-smectite. Having drawn these conclusions, it was reassuring to see in Figure 5 that the nonoxidative and oxidative assemblages, though portrayable on the same diagram, occupy different parts of it without overlap, and that all phyllosilicates except celadonite lie well outside that area of the diagram occupied by oxidative diagenetic assemblages. The implications of the restrictions on mineral formation under oxidizing conditions will be discussed further under oxidative diagenesis.

\section{Phillipsite}

Phillipsite is Fe-free and not sensitive to redox potential except in an indirect way due to its competition for constituents that also enter Fe-bearing diagenetic minerals. Phillipsite appears to be unstable in seawater as inferred by Rex (1967) from its etched appearance in altered rocks exposed to seawater, and also as inferred by the writer from its absence in rocks dredged from the crests of spreading ridges, in rocks that contain minerals known to alter to phillipsite and which are exposed on the sea floor in places other than ridge crests, and in the topmost layer of marine sediments except where winnowing, erosion, or bioturbation occurred. Therefore, phillipsite must have formed diagenetically (i.e., after burial). Most of it in basalts is found in rocks that underwent intense seawater alteration prior to burial and oxidative diagenesis after burial. The main substrate on or in which it forms in those rocks is altered glass at and near the surfaces of cooling units, and the vast bulk of it occurs in oxidatively altered rocks. Many of these rocks may never have entered the nonoxidative regime or else experienced its conditions only a relatively short time before resumption or inception of oxidative conditions. Phillipsite is relatively uncommon in the interiors of flows and pillows.

Despite the strong association with oxidatively altered rocks, and regardless of the prominent brown, orange, and red colors of Fe oxide-pigmented phillipsite veins in basalts from Hole 320B (among the most outstanding phillipsite occurrences in Leg 34 rocks), much of the phillipsite is associated with nonoxidative diagenetic minerals or their oxidation products, and it probably formed during nonoxidative alteration. This conclusion seems firm in the case of Sample 321-14-1, 113-121 cm, in which phillipsite coexists with marcasite and pyrite. Other cases of nonoxidative diagenetic phillipsite are those in which it is associated with green smectite or oxidized smectite which retains vestiges of green color; these are found in basalts from Holes 319A, 320B, and Site 321 (Tables 2, 3, and 4). Indirect, circumstantial support for a nonoxidative origin comes from the fact that in no case is phillipsite definitely associated with goethite. The most striking occurrences, however, are on the walls of vesicles. These are seen as the linings of hollow vesicles or in thin section as small clusters of crystals on the outer surfaces of amygdules; for example, 319A-2-1 and 319A-3, CC. They were also detected in X-ray patterns of amygdules (e.g., 321-14-1, 86-92 cm). In addition, some of the colorless grains in the altered mesostases of coarser grained rocks may be phillipsite (see section above on nonoxidative diagenesis of primary phases). These occurrences and possible occurrences of phillipsite may owe their existence to the compositions of the pore fluids rather than special substrates, but the phillipsite on vesicle walls may reflect the importance of a glass substrate in promoting its formation in a manner directly homologous to that in which palagonite (and sideromelane) substrates at the surfaces of cooling units act.

\section{Quartz}

Quartz in submarine basalts is an obvious, but not abundant constituent only in rocks that show clear and unmistakable evidence of metamorphism under conditions of the greenschist and low amphibolite facies. The writer has seen too few cases of zeolite-facies basalts to comment on its frequency of occurrence in them. In those submarine basalts which have undergone only seawater and diagenetic alteration at low temperatures, quartz and other forms of silica (opaline or crystalline) are rare or absent. Leg 34 rocks are no exception. Nonetheless, quartz is locally found in trace amounts in 
veins and amygdules, including some in Leg 34 rocks. Bunch and LaBorde (this volume) report a pure silica phase in the groundmass of one basalt. The writer found an uncertain trace of quartz in a vein from Hole 319A, and trace to minor amounts in veins and amygdules from Site 321.

This scarcity of quartz in typical, unmetamorphosed basalts dredged from scarps and ridges and cored during DSDP requires emphasis because casual comments by many students of such basalts indicate a belief that quartz is common. These statements reflect in part uninformed, intuitive articles of faith about low-grade rocks in general, and in part a tendency to include low-grade metamorphism in the same category as "submarine alteration" (embracing seawater alteration and diagenesis in the sense of the present paper).

One need not seek far for the reasons why quartz is scarce. The basalts are not rich in silica to begin with. The main secondary silicate, smectite, is almost as silica saturated as its host rock when their respective normative mineral assemblages are calculated with $\mathrm{Fe}$ in the same state of oxidation. Thus, little excess silica is available, and in fact the restricted availability may be essential to the formation of smectite and other clay minerals since, as pointed out by Harder (1971), polymerized silica groups in solution inhibit the formation of ordered clay-mineral lattices. The formation of both clay minerals and diagenetic quartz at low temperatures seems to require, or at least to be favored by, monomeric silicic acid. Where free silica is locally available beyond the demands of smectite, then other, silica-richer phases like celadonite and talc can form. In fact, the relatively minor abundance of talc probably reflects the limited silica supply. Where free silica is available in the absence of other constituents or conditions favorable to smectite, celadonite, or talc, then quartz can form. These observations bear on and help explain the difficulties encountered above (see discussion of mica) in the attempt to portray the nonoxidative diagenetic assemblages in terms of the mineralogical phase rule. Where an immobile component appears as a pure phase, one can eliminate it as one of the components needed in the phase-rule treatment of the remaining phases. In the treatment of the nonoxidative diagenetic assemblages above, such a simplifying reduction in the number of components was not possible as regards silica because of the absence of quartz or some other silica polymorph.

In the basalts from Hole 319A and Site 321 the known or possible quartz is always associated with smectite and in some cases with talc, as expected from the reasoning above. Where the quartz occurs in oxidized veins or in association with goethite, it may have precipitated during oxidative diagenesis when silicates were not being precipitated. In any case, its occurrence is erratic.

\section{Todorokite and Birnessite}

These hydrous $\mathrm{Mn}-\mathrm{Fe}$-oxide phases are the main crystalline constituents of Mn nodules, crusts, and veins. In the present study only relatively well-crystallized occurrences could be identified with certainty. Poorly crystallized or amorphous substances of similar com- position could be inferred only from color and opacity. Todorokite is a partially reduced phase, birnessite a completely oxidized phase. Extensive, as yet unpublished observations by the writer indicate that the encrustations and pavements formed in direct contact with seawater rarely, if ever, contain these minerals in forms sufficiently well crystallized to give recognizable peaks in X-ray diffraction patterns made with powder smear slides and goniometer-type diffractometers (long exposures with powder cameras may show broad peaks with the same material, and weak, secondary, nondiagnostic peaks are sometimes seen with smear slides). The well-crystallized materials form only diagenetically. The burial depth may be only millimeters, but burial appears to be essential in restricting the rate of oxidation which, in turn, controls the ability of todorokite to form at all or survive, and the rate of nucleation (hence, grain size and crystallinity) of birnessite. While todorokite probably does not form during oxidative diagenesis, it is not correspondingly true that birnessite cannot form during nonoxidative diagenesis. As indicated above, significant oxidation of Fe occurs, even during "nonoxidative" diagenesis. In treating $\mathrm{Mn}$, we cannot speak in such gross fashion of oxidizing and nonoxidizing conditions, but must get involved with the nuances of absolute redox potentials. For present purposes, suffice it to say that at the more reducing end of the range of conditions subtended under the term "nonoxidative" diagenesis, todorokite can and apparently does form. At the more oxidizing end of that range birnessite can form and todorokite may be unstable. Given the limited rate of supply and oxidation of $\mathrm{Mn}$, the birnessite may be able to nucleate and grow slowly, thus producing much better crystallized birnessite than ever found in $\mathrm{Mn}$ nodules, crusts, and pavements, and in veins formed during oxidative diagenesis under strongly oxidizing conditions. Thus, although most of the Mn oxides observed in Leg 34 basalts occur at or near the surfaces of cooling units, and are X-ray-amorphous and believed to have formed during oxidative diagenesis, some of them occur several to many centimeters away from those cooling surfaces and are sufficiently well crystallized to yield recognizable diffraction peaks even when highly diluted by other vein constituents. It is such $\mathrm{Mn}$ oxides that are properly discussed in this section on nonoxidative diagenesis, and they must be understood in the terms outlined above, as will be developed in the discussion of certain individual occurrences below. Such $\mathrm{Mn}$ oxides have been found in basalts from all four holes, but especially those from Holes 319A, 320B, and Site 321.

The best argument for nonoxidative Mn oxides is the single occurrence of todorokite without birnessite or goethite (319A-5-1, 141-144 cm; Table 2). It coexists with calcite and smectite.

As discussed under aragonite above, stellate splays of aragonite prisms may be embedded in dark brown oxides. In 319A-2-3, 39-40 cm, the oxides prove to be goethite, birnessite, and traces of todorokite, in association with aragonite, calcite, and smectite. While the goethite argues for an oxidative diagenetic origin, the todorokite and the association with aragonite suggest 
that deposition of the Mn oxides began during earlier nonoxidative diagenesis. The surviving todorokite was probably protected in the interiors of birnessite crystals or polycrystalline masses formed by oxidation of the outer parts of the original todorokite grains or masses. similar $\mathrm{Mn}$ oxides associated with presumed aragonite prisms (now prismatic molds) were seen in 319A-7-1, 88$93 \mathrm{~cm}$, but were not X-rayed.

In Sample 320B-5-1, 118-121 cm, from the interior of a pillow or thin cooling unit, well-crystallized todorokite and birnessite coexist with minor goethite in a dark red vein which has an irridescent metallic luster. Both $\mathrm{Mn}$ oxides are believed to have formed during nonoxidative diagenesis, and the later oxidative diagenesis did not destroy the luster or produce much goethite. In some phillipsite veins from Hole 320B (Table 3) minor, wellcrystallized todorokite and birnessite indicate deposition under conditions of restricted oxidation. The single occurrence of well-crystallized birnessite from Hole 319 (Table 1) may have formed under similar conditions.

The most striking case of presumed nonoxidative diagenetic Mn oxides is one of the two from Site 321 (321-14-1, 9-15 cm, Table 4). There the abundant birnessite and traces of todorokite are associated with abundant calcite and goethite, minor quartz, and traces of smectite. At first sight the ochre to rusty vein coloration suggests formation during oxidative diagenesis, and the abundant goethite lends support to this suggestion. The birnessite could then be regarded as having formed either under the same conditions by oxidation of earlier, nonoxidative todorokite, of which protected remnants survive inside the birnessite, or by direct precipitation from solution, or both. Three observations speak against such an origin for the birnessite. The first two are the existence of smectite and todorokite, neither of which is believed to form during oxidative diagenesis. The third is the crystallinity of the birnessite itself, the best ever seen by the writer, and so much better than that of any birnessite previously seen by the writer or reported in the literature that he misinterpreted the mineral initially as "ferric chamosite(?) or ferric kaolinite(?)" (Bass, 1974, p. 646). Further testing and a qualitative electron probe chemical analysis of the birnessite fused with quartz in a mixture of lithium tetraborate and $\mathrm{La}_{2} \mathrm{O}_{3}$ (preparation of fused bead by $\mathbf{J}$. Nelen, U.S. National Museum) confirmed its identity as a hydrous Mn oxide with small but significant amounts of $\mathrm{Fe}, \mathrm{Mg}, \mathrm{Al}, \mathrm{Na}$, and $\mathrm{Ca}$.

The only other occurrences of comparably wellcrystallized birnessite known to the writer are small, black botryoids on the faces of analcite in drusy veins in metabasalt dredged from the southern end of Coiba Ridge in the Gulf of Panama (M.N. Bass, unpublished data); a fragment of a 6-cm-thick vein of birnessite dredged from the Mariana Trough (Hanor, 1971); and hydrothermal-"spring" $\mathrm{Mn}$ deposits composed of birnessite and traces of todorokite from the TAG Hydrothermal Field in the median valley of the MidAtlantic Ridge (Scott el al., 1974; originally called todorokite by Scott et al., 1973). The oxides in these three occurrences are very poor in $\mathrm{Fe}$, hence do not turn brown on exposure to oxygenated seawater, as do birnessite and todorokite which form at ambient seawater temperatures, and demonstrate clearly that birnessite is stable (or metastable) in seawater. Both direct and strongly suggestive evidences indicate that the Fe-poor, well-crystallized birnessites are of hydrothermal origin.

Thus, the high degree of crystallinity of the Leg 34 birnessite suggests that it too is hydrothermal, and, as such, would be the only vein mineral aside from deuteric chlorite, talc, and possibly smectite in the Leg 34 veins that would appear to have formed at high temperature. In this way, the suggestion of hydrothermal sulfides (Field et al., this volume; but note that sulfides do not coexist with birnessite) and other hydrothermal components in the veins (Scott and Swanson, this volume) would find support. However, several features distinguish the well-crystallized Leg 34 birnessite from the other occurrences of similarly well-crystallized birnessite. For instance, whereas the others occur to the virtual exclusion of other contemporaneous vein minerals, the birnessite in 321-14-1, 9-15 cm coexists with calcite, goethite, smectite, and quartz, any of which may be contemporaneous with the birnessite; further, neither the assemblage nor any textural or other feature of any of the minerals associated with the birnessite suggests that it is of hydrothermal origin. The calcite, for instance, contains less than 1.5 mole $\% \mathrm{MgCO}_{3}$, which is less than in most vein calcites from Site 321 (Figure 5), in contrast to the higher concentrations that might be expected in hydrothermal calcite (see Katz, 1973, for distribution coefficients of $\mathrm{Mg}$ in the low hydrothermal temperature range; the increase of solubility of $\mathrm{Mg}$ in calcite at very high temperatures has long been established). Further, while the wellcrystallized, Fe-poor birnessites elsewhere are black and do not discolor on exposure to oxygenated seawater, the birnessite from Site 321 is dark brown or red-brown, in conformity with the qualitative microprobe data that indicate a significant $\mathrm{Fe}$ content. Also, while the Coiba Ridge botryoids studied by the writer are microcrystalline, the birnessite from Site 321 is in relatively large flakes which are easily seen under a binocular microscope to occur in parallel to subradial books; and, in thin section, individual crystals are seen to project into adjacent calcite.

The interpretation preferred by the writer is that the birnessite grew diagenetically under such circumstances that nucleation was suppressed, in contrast to the rapid nucleation that seems to dominate the crystallization of birnessite that forms by oxidation of todorokite at or near the sediment-water interface. Given only a few nuclei and slow growth, the birnessite grew to larger, better ordered crystals than have commonly been found. The other cases of birnessite listed in Tables 1-3 are somewhat unusual in the ease and relative sharpness with which even weak X-ray peaks were seen. If those birnessites could be concentrated, as was the relatively abundant birnessite in Sample 321-14-1, 9-15 cm, they too might well be found to be well crystallized. Thus, diagenetic birnessite (and todorokite) in interior veins in oceanic basalt may be commonly or typically well crystallized and may have to be distinguished from 
hydrothermal birnessite on other grounds, such as minor and trace element contents. The interpretation offered by the writer, namely, slow nucleation and growth during diagenesis, is not specific as to a nonoxidative or oxidative regime. The goethite which is associated with the birnessite in several cases, often in large amount, suggests oxidative diagenesis. If so, then any todorokite would be assigned to an earlier nonoxidative period and a two-stage origin of the Mn oxides and associated minerals would be implied. This is indeed a likelihood that conforms to many other evidences discussed in this paper for a complex paragenesis of the veins.

\section{OXIDATIVE DIAGENESIS}

Oxidatively altered basalts and veins are characterized by yellow, brown, and red colors due to independent, highly colored ferric $\mathrm{Fe}$ compounds, mainly goethite and X-ray-amorphous products classed variously as limonite or "iron stains," with lesser, sporadic occurrences of hematite. Despite the radical color distinction from the gray, nonoxidatively altered basalts, the assignment of certain minerals to the nonoxidative or oxidative regime of diagenesis is not always clear, as evidenced by the necessary cross-references to oxidative effects and phases in the above discussion of nonoxidative diagenesis. From the mixed discussion one might conclude that the changeover from one regime to the other is gradual and the distinctions blurred. That, however, is not the case. Goethite is not associated with green or blue-green smectite, chlorite, talc, pyrite, marcasite, or aragonite in such a manner as to suggest stable coexistence. Wherever goethite is associated with one or more of those minerals, there is a zone, selvage, patches or spots of yellow, brown or red material, and commonly with clear to suggestive remnants of green phyllosilicates. These occurrences are mechanical mixtures, and they indicate an abrupt transition from one set of conditions to another, with the intermediate state of destruction of some phases and creation of others dependent on kinetics rather than stability of the phases. In contrast, there are cases from which one can argue that goethite and celadonite formed contemporaneously and in equilibrium, but these cases are less disturbing since celadonite is a ferric Fe compound.

The complete understanding of the transition is not simple, and it is at this juncture that the writer reemphasizes the caveat expressed in the opening paragraph of the introduction that the working hypotheses presented here are tentative and incomplete. As discussed earlier, nonoxidative diagenetic smectite and celadonite are rich in ferric $\mathrm{Fe}$, more so than the host basalts, which indicates active oxidation during nonoxidative diagenesis, but at a rate sufficiently low that the diagenetic phases can incorporate the ferric $\mathrm{Fe}$ in octahedral lattice sites without formation of nonsilicate ferric Fe phases. One might then surmise that if, under the action of a copious supply of oxygen, ferric Fe were to form in such amounts or at such a rate that it could not be wholly incorporated in smectite, etc, then goethite and other ferric Fe phases would form. This surmise fails in the cases of all but celadonite. We do not see the expected goethite-green smectite assemblages, for instance. Instead, concomitant with the formation of goethite, smectite and chlorite turn yellow, brown, or red, and sulfides disappear. We then infer that either smectite (and chlorite) or goethite (and limonite and hematite) forms in a given set of circumstances, but not both, and the advent of goethite-forming oxidative conditions is accompanied by the destruction or alteration of all Fe-bearing nonoxidative diagenetic phyllosilicates other than celadonite (talc appears to survive).

The progress of the alteration can vary. In extreme cases the smectite is utterly destroyed. Initially, or under less severe conditions, though, it appears to change from an intrinsically green or blue-green mineral to a colorless mineral pigmented by $\mathrm{Fe}$ oxide dust and patches, as can be seen under a petrographic or even a binocular microscope in cases where the $\mathrm{Fe}$ oxide pigment is not overly abundant or not so finely dispersed that it obscures the intrinsic color of the host smectite. The nature of the change evidently involves oxidation of ferrous $\mathrm{Fe}$ and a rebalancing of charge, not by loss of hydrogen ion, as at high temperature in the formation of oxyhornblende, but by elimination of excess ferric $\mathrm{Fe}$ as dust and crystallites. The resulting colorless smectite is presumably more nontronitic and more nearly dioctahedral than its green predecessor. Contrary to the green smectites, which expand easily with glycol or water, and which develop shrinkage cracks and decrepitate on alternate wetting and drying, the oxidized smectites expand more slowly (but ultimately to the same extent) with glycol, do not crack and decrepitate so much, are more brittle (in contrast to the waxy, highly sectile green smectites), and are more poorly crystallized (as indicated by weaker, broader X-ray diffraction peaks). The crystallinity suggests that the oxidation does not always involve a simple isomorphous replacement of some cations in an Si-Al-framework which is, on the whole, preserved intact, and with preservation of original grain sizes and boundaries; instead, it may involve recrystallization to smaller grains, or at least the creation of an imperfect mosaic structure or other types of defects or smaller lattice domains.

A special case of oxidative alteration of a phyllosilicate is seen in Sample 319A-4-1, 114-119 cm, in which black deuteric chlorite (and minor smectite) is replaced, not by dusty $\mathrm{Fe}$ oxide, but on a macroscopic scale by spherules of goethite. The surviving chlorite remains black or dark green and has not been converted to a colorless material pigmented by $\mathrm{Fe}$ oxide. This may reflect differences in the behaviors of chlorite and smectite toward oxidation, although other chlorite-rich veins are oxidized yellow or brown.

Where large olivine grains, partially altered to smectite during nonoxidative diagenesis, are later oxidatively altered, the resulting compound pseudomorphs are composed of oxidized smectite enclosing cells of earthy $\mathrm{Fe}$ oxide, with or without remnants of olivine. Where remnants occur, they are yellow or red stained. Good examples of compound, oxidatively altered pseudomorphs after olivine were selected from Hole 319A, Core 3, Sections 3, 4, and 5 (Table 2) and X-rayed. They are composed of smectite, hematite, and possibly a trace 
of talc, which, if present, probably formed during the initial nonoxidative diagenesis. These pseudomorphs are indistinguishable from those produced by seawater alteration in near-surface parts of cooling units upon direct attack by oxygenated bottom waters prior to burial by sediments.

Except for olivine, the only other primary mineral that reacts at appreciable rates during oxidative diagenesis is titanomagnetite, which is altered through a continuous series of titaniferous maghemomagnetites toward maghemite (Bass et al., 1973a, p. 435, Table 5, plus discussions in text). This subject is reviewed more thoroughly by Ade-Hall et al. (Petrography of Opaque Minerals) elsewhere in this volume with emphasis on the changes in rocks cored during Leg 34 . The susceptibility of titanomagnetite to oxidative diagenesis is in stark contrast to its evident stability during nonoxidative diagenesis.

The rate of oxidation of primary igneous and nonoxidative diagenetic minerals was rapid compared to the rate of supply of oxygen by diffusion. As soon as an oxygen atom reached a phase susceptible to oxidation, it reacted, thus creating and maintaining a sharp boundary (Figure 6) that marks a front along which the oxidizable phases are "titrated." Normally this reaction front corresponds identically to the color boundary, but locally the color boundary is at least in part due to another factor, especially in those cases where narrow wedges of brown or red coloration extend along an especially permeable vein well ahead of the main color front in the unfractured interiors of the adjacent blocks. This factor is the oxidation of sulfides, which generates ferric sulfate dissolved in a sulfuric acid medium:

$$
4 \mathrm{FeS}_{2}+15 \mathrm{O}_{2}+2 \mathrm{H}_{2} \mathrm{O}=4 \mathrm{Fe}^{+3}+8 \mathrm{SO}_{4}=+4 \mathrm{H}^{+}
$$

The resulting ferric Fe remains in solution and diffuses along the vein and into the adjacent wall rocks until the sulfuric acid is neutralized and the $p \mathrm{H}$ raised to a value at which hydrous ferric oxides precipitate. Thus, at least part of the iron stain adjacent to veins is not due to oxidation of the local primary minerals, but to ferric $\mathrm{Fe}$ generated by oxidation elsewhere in a nearby vein. Local patches of intense brown or red color in or along a vein, or relatively wide zones of brown discoloration flanking oxidized veins in otherwise unoxidized host basalt may record the positions of relatively sulfide-rich portions of the original nonoxidative diagenetic veins. It is not inconceivable, though perhaps unlikely, that, as a result of this process, one could find Fe stained but essentially unoxidized green smectite and sulfides. The sulfate remains in solution and may diffuse out of the system entirely. The oxidation of sulfides in the host basalts and similar loss of the resulting sulfate account for the radical reduction of $\mathrm{S}$ contents in oxidatively altered basalts.

The juxtaposed gray, nonoxidatively altered rocks and brown, oxidatively altered rocks are mechanically identical so far as hardness and coring properties are concerned. The basalts do not break or wear differentially along the color boundaries during drilling where a joint or vein is not involved. The sharp, diffusion- controlled boundaries between the color variants of the basalts conform in a general way to joints and veins which appear to have been preferred avenues of ingress of oxygen. The initial joint-bounded blocks are angular, but their residual, unoxidized kernels are more ovoid or rounded. Nonetheless, the gross shape of a residual kernel reflects the original shape of its parent block if the size of that kernel is still a considerable fraction of that of the original block. Thus, even where the joints and veins are not visible in a core, their general configuration can be readily inferred from the topology of the color boundaries in the core. In this way it was possible to correlate efficiency of core recovery with spacing of joints and veins and the correlative sizes of joint blocks. In general, good recovery was associated with widely spaced joints and veins, as might be expected. Flat or gently dipping joints and veins virtually invariably led to parting and differential rotation of core segments, with destruction of the joints and veins and rounding of the edges of the core segments, but also with frequent preservation of the discolored zones of oxidative alteration that flanked the joint or vein. The frequency of oxidized zones decreases in general inward from the original surfaces of cooling units, but this correlation is erratic and inexact, depending as it does on the distribution of joints. Most of them are perhaps cooling shrinkage cracks that increase in frequency toward quenched surfaces, but any original mechanical heterogeneity may have modified this distribution, and some of the joints are secondary fractures developed in the cold rocks during spreading-related tectonism which was probably most severe early in the spreading history of the igneous body near the ridge crest at which it was erupted and during the early, near-crestal rapid drop in elevation of the crust.

Certain specifics of oxidative diagenesis are brought out below in discussions of individual phases, some of which extend and amplify observations discussed under nonoxidative diagenesis. No chlorite, RML chloritesmectite, talc, aragonite, sulfide, or todorokite is assigned an oxidative diagenetic origin.

\section{Smectite}

As pointed out above under nonoxidative diagenesis, pure smectite does not appear to form during oxidative alteration. The only expandable clays produced occur as random interlayers in mica-smectite complexes, and the assignment to oxidative diagenesis is uncertain. For some time the writer had concluded that oxidative conditions inhibit the crystallization of phyllosilicates in general (except celadonite) and smectites in particular in seawater and in marine diagenetic environments. Support for this was found in the rarity of proven cases of marine nontronite, despite widespread, but unsupported, claims to the contrary (the only analysis of a marine nontronite known to the writer is his own of a platy, earthy fragment of very poorly crystallized smectite dredged from the south scarp of the Clipperton Trough just northeast of Clipperton Island). Therefore, he was surprised to find the great preponderance of ferric over ferrous $\mathrm{Fe}$ in the analyzed smectite from Site 321 (see above). More recently he found reference to the syn- 
thesis of dioctahedral, ferric Fe-rich clays, including smectite, in aqueous solutions at temperatures from $3^{\circ} \mathrm{C}$ to $20^{\circ} \mathrm{C}$ (Harder, 1973). The occurrence of nontronite in terrestrial, fresh-water environments, such as the Columbia River Plateau basalts, is well established. It seems, therefore, that, even though crystallization of ferric Fe-rich smectite from real or artificial seawater has not been conclusively demonstrated, there is at least suggestive evidence that it is not impossible, and the empirical failure of phyllosilicates to crystallize in notable quantities during oxidative diagenesis must be due to some as yet unknown factor other than the high redox potential. It is apparently not a high concentration of ferric ions since their concentration is buffered at very low values by the precipitation of goethite and limonite (Cooper, 1938; Garrels and Christ, 1965, p. 95-97, 110111). The controlling factor may be, not the high concentration of some poisoning substance, but a dearth of a necessary component such as dissolved $\mathrm{Al}$ or Si. Comment was already made in the discussion of nonoxidative diagenesis on the possibly limiting role of Si supply (see especially the discussion of quartz), and further comments to this same effect will be made in the discussion of phillipsite below.

Regardless of the cause, if we grant that little or no new smectite forms during oxidative diagenesis, we can understand an otherwise puzzling observation regarding the degree of alteration of oceanic basalts. The Leg 34 basalts are poorer in $\mathrm{H}_{2} \mathrm{O}$ than other dredged and drilled oceanic basalts of comparable age heretofore analyzed. This is supported by Muehlenbachs (this volume) who finds that the $\delta \mathrm{O}^{18}$ values of total rocks vary directly with the water contents. The previously analyzed basalts were mainly quenched to very fine-grained rocks sampled immediately below glassy selvages since these were the rocks most commonly plucked by the dredge from pillowed surfaces or drilled during the shallow basement penetration of most DSDP holes. The Leg 34 rocks, on the other hand, include both coarse-grained basalts and diabases from the interiors of cooling units, as well as quenched, near-surface basalts. Even within the Leg 34 rocks, taken as an independent subgroup of submarine basalts, it can be seen that coarser grained rocks are lower in water content than the finer grained rocks. This is somewhat surprising since, both in hand specimen and in thin section, one can see patches of smectite after olivine and mesostasis in the coarser grained rocks, whereas the fine-grained, quenched rocks are generally much harder and show little readily visible smectite. The visual impression is reinforced by total-rock X-ray analysis. The coarser grained rocks give distinct to moderately strong basal reflections of smectite (Tables 2 and 4), the fine-grained rocks only weak reflections or none at all. The hydrated phase in the fine-grained rocks is not at all evident.

The resolution of this puzzle is as follows. The coarser grained interior rocks initially underwent nonoxidative alteration during which the easily altered phases (olivine and mesostasis) were converted largely to smectite, which is readily visible. But the amount of such alterable phases was limited and the rate of alteration rapidly diminished to that controlled by the relatively resistant plagioclase, clinopyroxene, and titanomagnetite.
The fine-grained, quenched rocks from near cooling surfaces contained abundant glass interstitially and between the arms of spherulites, dendrites, variolites, and skeletal crystals. Those rocks either immediately entered a regime of oxidative alteration, or the initial nonoxidative alteration rapidly gave way to oxidative alteration as oxygen diffused in. Thus, smectite either did not form or its formation was soon terminated. The remaining glass and olivine were then converted to amorphous or poorly crystalline phases which are hard to see macroscopically or microscopically or to identify by X-ray analysis. They probably include limonite, poorly crystallized goethite, and palagonite-like products, all tending to give the brown to red-brown colors which characterize near-surface joint blocks (yellow in the lower part of Hole 320B). It is not meant to imply that no smectite is present. As discussed above under seawater alteration, the rapidly nucleated, tiny crystals of smectite in palagonite do not give welloriented smear slides, so the basal smectite reflections do not show up prominently. The cleavages of tiny smectite crystals developed in the interstitial glass of the quenched rocks would not control fracture of the rocks during the grinding of powders, so the irregular to conchoidal fractures of skeletal crystals and amorphous palagonite would control the orientation of grains, giving random smectite X-ray patterns without strong basal reflections (e.g., 321-13-4, 127-132 cm, Table 4).

The abundance of alterable phases (mainly glass) and/or the water content of the alteration products is high in the fine-grained rocks, so they typically have high water contents. There is some evidence (Ridley et al., 1974, p. 142, 149-150) that the Fe-rich rims of groundmass clinopyroxene grains in the quenched rocks are oxidized during oxidative diagenesis, thus providing additional hydrous $\mathrm{Fe}$ oxides.

\section{Calcite}

Calcite interpreted as having formed during oxidative diagenesis is quite varied in appearance. It occurs as veins of the linings of cavities. Very little amygdular carbonate is believed to have formed under oxidative conditions, but such a conclusion is tenuous. In Hole 319 the calcite occurs as red or white, very fine-grained veins, the red veins being up to $3 \mathrm{~mm}$ thick and pigmented by dusty Fe oxides. Spalls of dark basalt, easily seen against the light background of the dense red veins, are enclosed in the veins (e.g., 319-13-1, 97-103 cm and $116-126 \mathrm{~cm}$ ) and clearly attest to tensional opening of the cracks now occupied by the veins.

In Hole 319A the only calcite thought to have formed during oxidative diagenesis occurs as drusy crystals and rarely as botryoidal masses in cavities in both interior and near-surface veins. Many of the drusy crystals are conical, striated crystals, much like dog-tooth scalenohedra with abundant vicinal faces, which taper outward from the walls of cavities and commonly occur in clusters of interfering crystals. They superficially resemble the wheat seed-shaped crystals of magnesian calcite synthesized by Towe and Malone (1970) except that those crystals are doubly tapering and did not grow from a substrate as did the natural conical crystals. Similar or identical conical, striated crystals were first 

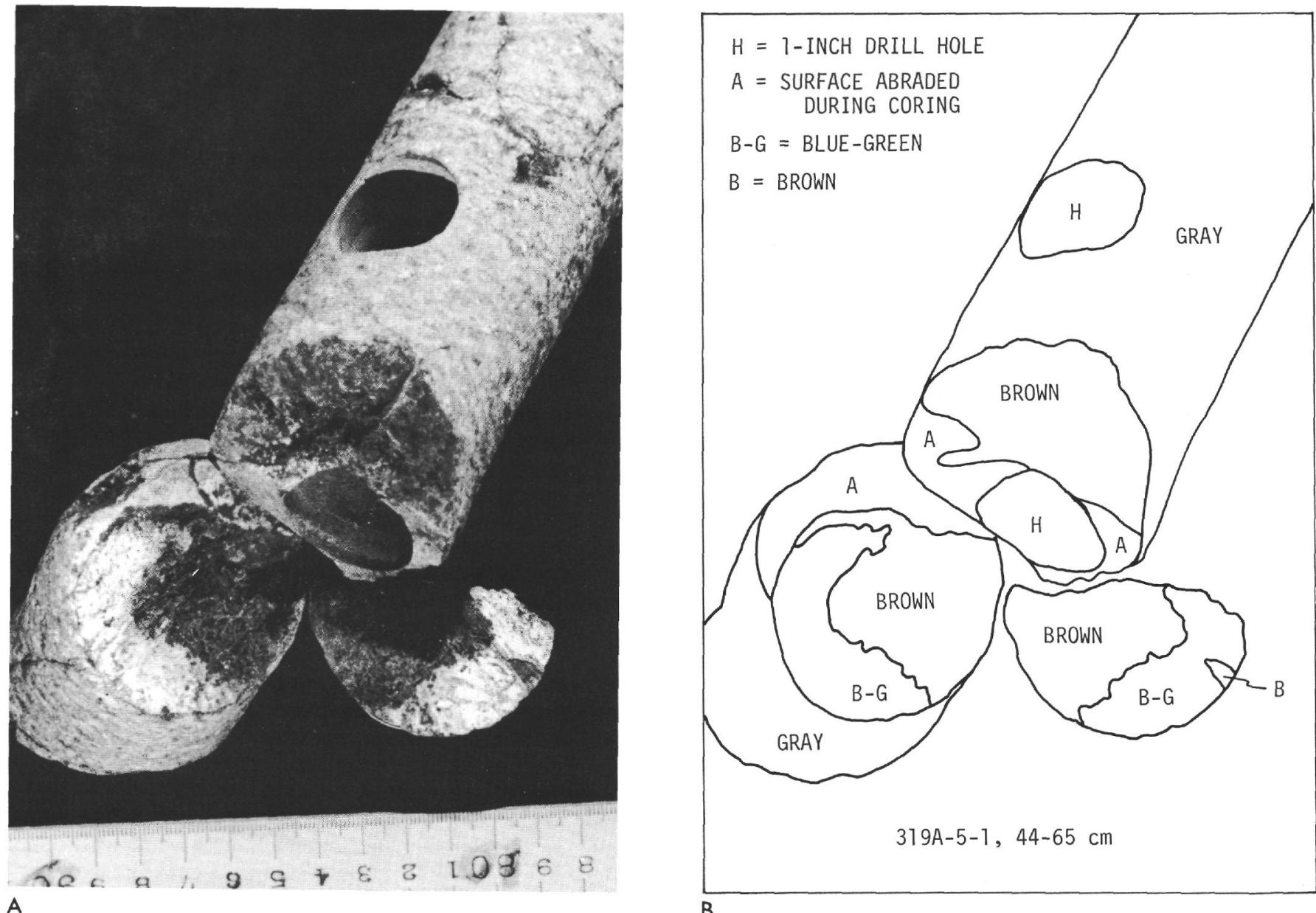

Figure 6. (A) and (B) are an exploded view showing a vein in which a sharp, diffusion-controlled oxidation front separates blue-green, nonoxidative diagenetic smectite from its brown oxidative diagenetic product. There is almost no brown discoloration in the adjacent host rock; a similar lack of discoloration is true also adjacent to similarly oxidized veins shown in the upper part of Figure $6(\mathrm{~A})$.

observed by the writer in drusy veins in basalt from the Experimental Mohole (unpublished; based on study of cores in the repository of the Scripps Institution of Oceanography), and have since been observed by him, not only in DSDP cores, but on the walls of vesicles in very fresh, young basalts from the median valley of the Mid-Atlantic Ridge. Thus, this crystal morphology would seem to reflect a certain physical and chemical environment rather than age of the host basalts. In experiments on the kinetics of the inversion of aragonite to calcite, Bischoff and Fyfe (1968) found that the calcite grew as rhombohedra except in the presence of $\mathrm{SO}_{4}=$ ions, where it grew as scalenohedra. The conical calcite crystals, if they are scalenohedra, may have responded to a similar influence of $\mathrm{SO}_{4}=$ ions which were present as a result of the oxidation of nonoxidative diagenetic pyrite and marcasite. In the vesicles of young basalts, as in the median valley of the Mid-Atlantic Ridge, the $\mathrm{SO}_{4}=$ rich solutions may have been provided by the oxidation of late magmatic sulfides on the walls of the vesicles (see Mathez and Yeats, this volume, for striking occurrences in Leg 34 basalts and other references). Indeed, the conical crystals in the vesicles of Mid-Atlantic Ridge basalts observed by the writer were commonly nucleated on small masses of orange or red hydrous $\mathrm{Fe}$ oxide which the writer inferred, both from their compositions and from the cubic(?) pseudomorphous shapes of some of them, to be oxidation products of sulfide, probably pyrite. The association of calcite with oxidized pyrite puzzled him until he ran across the observation of Bischoff and Fyfe (1968).

Oxidative diagenetic calcite from Hole $320 \mathrm{~B}$ is commonly a minor constituent of veins composed largely of phillipsite and smectite. This scarcity is consistent with the paucity of carbonate veins in near-surface parts of cooling units, such as those parts constituting virtually the whole igneous rock recovery at Site 320 .

The calcite veins assigned an oxidative diagenetic origin in basalts from Site 321 are white and dense, or granular (and relatively coarse grained), or cross-fiber and silky lustered on fractured surfaces. All occur near, but not at, the top contact of the thick cooling unit sampled at Site 321. Partially filled vesicles in the thick unit contain conical or dog-tooth crystals and rounded lumps or botryoids of calcite.

It is possible that much of the calcite in veins assigned to nonoxidative diagenesis in basalts from Hole 319A and Site 321 originated by inversion from aragonite. If 


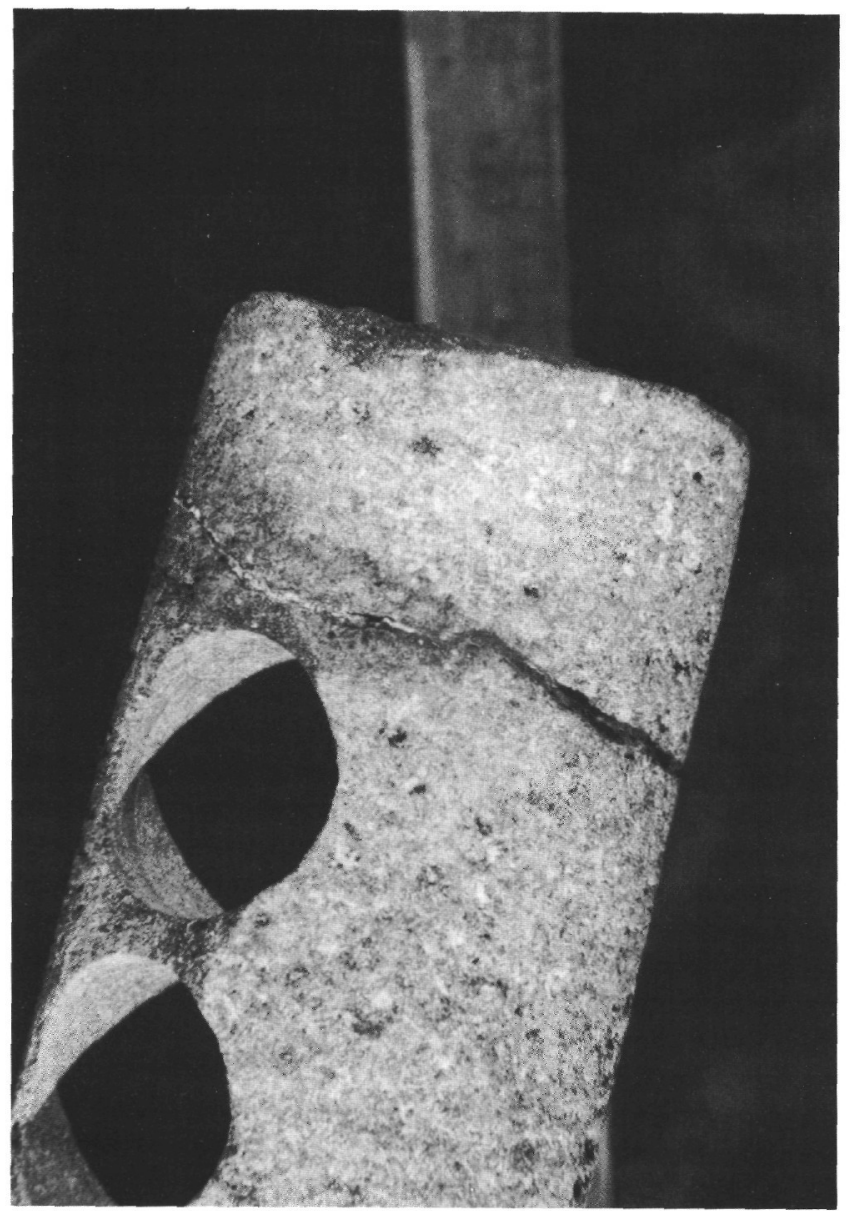

C

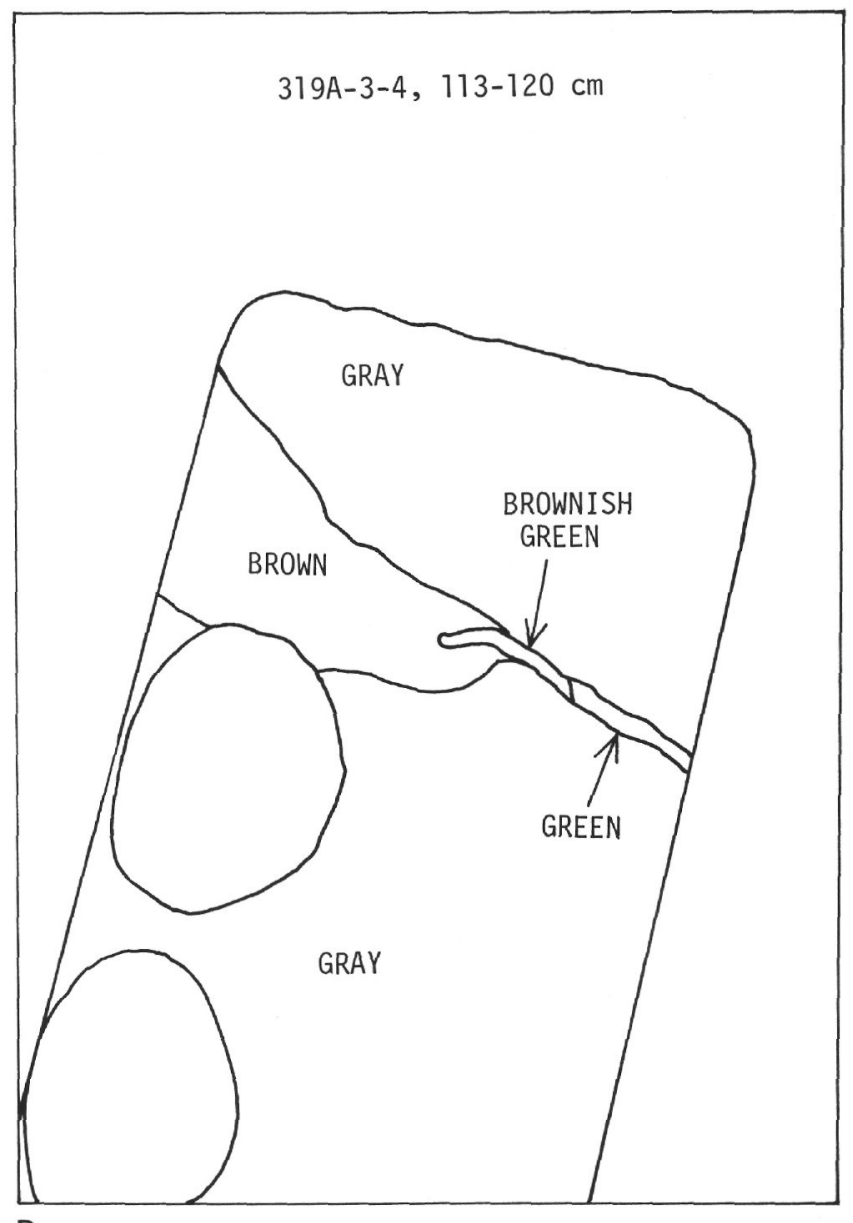

D

Figure 6. (C) and (D) show a sharply bounded wedge of brown oxidative discoloration on either side of an aragonite-smectite vein in otherwise gray, nonoxidatively altered rock. The oxidation of the smectite in the vein has advanced ahead of the discoloration in the wall rock. The wall rock discoloration may in part have resulted from oxidation of a local sulfide concentration in the vein (see text), of which non remains. The carbonate in the oxidized part of the vein is still aragonite. The dark spots in $(\mathrm{C})$ are green smectite after olivine phenocrysts. They and the fresh plagioclase phenocrysts (white spots in the upper right and elsewhere) are near the top of a "cumulate" zone in the lower part of the thickest cooling unit in Hole $319 \mathrm{~A}$ (see Table 2 and Figure 2). Samples for various investigations reported in this volume were taken from 1-in. cores of the type removed from the holes shown in (A) and (C)

so, and if the inversion occurred during nonoxidative diagenesis, then, in view of the unetched, uninverted, fresh appearance of the surviving aragonite, one would have to conclude that the calcite replaced an earlier generation of aragonite now wholly destroyed. On the other hand, essentially no aragonite survives in oxidative diagenetic veins except very near the color boundaries marking oxidation fronts (see below). Therefore, in such veins formed by the oxidation of earlier nonoxidative diagenetic veins, the calcite could have formed by inversion of aragonite and there is no fresh aragonite to limit the speculation. Indeed, there are definite suggestions that some of the calcite originated in this fashion. The basis for the suggestions is twofold, namely the instability of aragonite and the consequent likelihood of its inversion, and certain features of the calcite itself. While the case is not proved, the writer suspects that many vein calcites, especially the biaxial ones, formed by inversion of aragonite. $\mathrm{He}$ thinks that the difficulties attending an attempt to identify carbonates microscopically aboard ship should not deter such attempts, but questionable identifications should be checked by X-ray diffraction analysis. In many cases of biaxial calcite, minor remnants of aragonite confirmed by means of X-rays, may help establish an origin by inversion.

Although no aragonite is believed to have formed during oxidative diagenesis, aragonite can be found in brown, oxidized smectite veins within oxidatively altered or at least brown-stained host rocks, but only very near the oxidation front separating them from gray, nonoxidatively altered rocks (e.g., within that part of the otherwise green smectite vein in $319 \mathrm{~A}-3-4,113-120 \mathrm{~cm}$, which is enclosed within the lobe or prong of brown dis- 
coloration which has advanced along the vein; see Figure $6 \mathrm{c}, \mathrm{d}$ ). This shows that the oxidation of smectite can occur faster than the inversion of aragonite to calcite, and that oxidation itself does not necessitate inversion or cause it to occur immediately.

\section{Phillipsite}

Strong evidence was given above that much of the observed phillipsite formed nonoxidatively. Nonetheless, a still larger portion of it occurs at the surfaces of cooling units in sideromelane or palagonite and in immediately adjacent rocks. Many of these rocks never experienced nonoxidative diagenesis, and others spent little time in the nonoxidative regime before onset of oxidative conditions. Therefore, the bulk of phillipsite in the basalts formed under oxidative diagenetic conditions, just as did most or all phillipsite in the overlying sedimentary section. It would seem that some surface or near-surface condition may favor or be essential to the formation of phillipsite. This suggestion is strengthened by the fact that even those phillipsites that appear to have formed nonoxidatively occur mainly in thin cooling units or, if in thick ones, relatively near their surfaces (Tables 2, 3 and 4; Figures 2, 3, and 4). Thus, something from surface parts of flows may have influenced their formation also, by diffusion or by hydraulic flow of fluids from surface to interior parts of cooling units.

The phillipsite at the surfaces of cooling units almost always lies on palagonite rather than sideromelane, suggesting that the palagonite either formed before the phillipsite or continued to form after the phillipsite started forming. While both possibilities may be true, a pre-phillipsite origin of the palagonite is probably true in at least those cases where phillipsite fills cracks in sideromelane without intervening palagonite (e.g., 320B-3-1, 102-104 cm). In all cases the phillipsite was deposited on the surface of a substrate, be it palagonite, sideromelane, or the walls of a cavity. In no Leg 34 rock did the writer see actual volume for volume replacement by phillipsite, and this has been his experience through years of study of submarine basalts (he can recall only one case in which phillipsite replaced another material, in that case sideromelane). From these observations we must conclude that the phillipsite was deposited from solution, a conclusion which is not startling but requires emphasis. The control on its formation, then, would seem to be the supply of soluble constituents, mainly K, $\mathrm{Ca}, \mathrm{Al}$, and $\mathrm{Si}$. While $\mathrm{Ca}$ and $\mathrm{Al}$ do not seem likely to pose severe supply problems, $\mathrm{K}$ and $\mathrm{Si}$ might since the phillipsite must compete for the limited supply of them with other diagenetic minerals. It competes for $\mathrm{K}$ with $\mathrm{K}$-feldspar, celadonite, and smectite; for $\mathrm{Si}$ with those phases and all other diagenetic silicates. As pointed out above in the discussion of quartz, the limited Si supply may control the limited quantities of celadonite and talc as well as quartz. Phillipsite, while not a highly siliceous mineral (it is sparse or absent in quartz-bearing marine sediments and tuffs), nonetheless requires $\mathrm{Si}$ in its formation. While it probably derives $\mathrm{K}$ and possibly some Si from sources external to the basalt, its association with glassy surfaces of cooling units (and possibly glassy walls of vesicles; see discussion of phillipsite under non- oxidative diagenesis) may stem from a dependence on the labile, reactive glass as a source of $\mathrm{Si}$ and $\mathrm{Al}$. This suggestion gains support from the observed preferred association of free silica (quartz and opal) with palagonite-rich parts of basaltic volcanic piles, even alkali basalts. For instance, Tomasson and Kristmannsdottir (1972) report that hydrothermal quartz in Iceland is most abundant in hyaloclastites and tuffaceous sediments. The only quartz found by the writer on Mas-atierra, in the Juan Fernandez Islands, Chile, occurs as clusters of doubly terminated prisms in porous palagonite tuffs and breccias of alkali basaltic composition.

The near-surface occurrence even of nonoxidative phillipsite may depend on $\mathrm{Si}$ which is dissolved from glassy margins and diffuses inward along gradients created by the consumption of Si by the large bulk and number of diagenetic silicates forming in the interior. If the kinetics of phillipsite nucleation and growth are unfavorable relative to those of the various phyllosilicates in the interior, the phillipsite will tend to occur where the relative advantages are reversed. Near the surface of the cooling unit it may gain a competitive advantage from concentrations levels of solutes (such as relatively high $\mathrm{K}$ and low $\mathrm{Fe}$ ), while the other phases may be inhibited (by relatively high $\mathrm{fO}_{2}$, for instance).

Much of the phillipsite in the interiors of cooling units lines open cavities. These mark local environments where conditions like those near the surface are repeated. While such conditions may be locally determined, there is at least the possibility, suggested by the oxidative diagenetic veins enclosing large spalls of host basalt, that pore fluids are introduced into the interior from the surface when joints and veins are opened by extentional tectonism related to sea-floor spreading and the attendant crustal subsidence, or by compaction of the open pile of volcanic pillows and flows. The pore fluids are suddenly introduced from the near-surface parts of the cooling unit, from the interflow hyaloclastites, and/or from the overlying sediments. These fluids in essence transfer the near-surface solution chemistry, with few or no changes, to the interior of the cooling unit. Various oxidative diagenetic minerals are then precipitated in the interior. Where nonoxidative diagenetic veins were reopened, compound veins result. Oxygen brought in with the fluid oxidizes both the basaltic wall rocks and the nonoxidative vein minerals. And, since the chain of events begins with extensional opening of a fracture, the terminal event will be filling of the final cavities. Where the filling is incomplete, drusy crystals of oxidative diagenetic minerals coat the cavities. Among those are phillipsite and the conical, striated, dog-tooth crystals of calcite described above, with which phillipsite in the interiors of cooling units is often associated.

A general feature of relative mineral abundances, which does not show up clearly by inspection of Tables $1-4$, is that the correlation between phillipsite, on the one hand, and calcite and smectite, on the other, is not strong. They do coexist, but only in a limited way because, as a result of the preferential occurrence of phillipsite near the surfaces of cooling units, and of calcite and smectite in the interiors, only one or the 
other is generally abundant, and their coexistence in comparable amounts is restricted to the near-surface zone of overlap where one is dwindling as the abundance of the other is increasing.

An unanticipated correlation is seen in the frequent coexistence of phillipsite with traces of mica in Hole 320B (Table 3 and Figure 3). It is unlikely that the mica is detrital mica which seeped from the sediments into cracks later filled by phillipsite; this is both mechanically unlikely and excluded by the rarity of mica in the sediments. The alternative is that mica (presumably celadonite) and phillipsite crystallize together during oxidative diagenesis. The mica probably depends on a supply of soluble $\mathrm{Fe}^{+3}$, without which the available $\mathrm{Si}$ and $\mathrm{K}$ enter phillipsite. Some of the mica conceivably forms by replacement of smectite where there is a coupled influx of oxygen and $\mathrm{K}$.

\section{Goethite and Hematite}

Palagonite and many near-surface rocks are colored in various shades of orange, brown, ochre, and red, yet many of them give no goethite $\mathrm{X}$-ray reflections at all or only very weak ones. This is notably true in the rocks from Hole 320B. Goethite in the interiors of thick units is not abundant, but, where it occurs, it is relatively well crystallized. Where similarly well-crystallized goethite occurs in thin cooling units, such as those in the lower part of the section drilled in Hole 319A, it is found in rocks with a considerable cover of basalts, including a thick, massive unit in the case of Hole 319A that may have served as an impervious barrier that allowed conditions to develop in the thin cooling units that simulate those in the interiors of thick units. It is notable in this regard that the thin cooling units in the bottom of Hole 319A that contain well-crystallized goethite also contain the only todorokite without birnessite (or goethite), attesting to the restricted access of oxygen.

Hematite is uncommon. With the exception of that in the red pseudomorphs after olivine (Core 319A-3, Sections 3, 4, and 5; Table 2), it is always associated with goethite and occurs exclusively in the interiors of relatively thick cooling units.

The rationalization of these occurrences follows that offered above for nonoxidative birnessite. The oxidation of surface and near-surface rocks is so intense and "traumatic," so to speak, that the nucleation-growth properties of goethite do not allow development of wellcrystallized material, and the varicolored limonite stains ensue. In the interiors of cooling units, where the rate of oxidation is less, the fewer nuclei of goethite can grow or recrystallize more slowly and ultimately more extensively. The same growth opportunities are provided even in porous piles of pillows and thin cooling units immediately below the barriers provided by thick units. In accord with current views on the origin of hematite in redbeds as a diagenetic product produced by the aging of goethite and other hydrous $\mathrm{Fe}$ oxides, the hematite in the Leg 34 basalts is regarded as a diagenetic aging product of goethite under favorable circumstances.

\section{Mn oxides (Mainly Birnessite)}

Most of the Mn oxides observed in oxidatively altered rocks occurs as black spots, patches, films, joint coat- ings, dendrites, and, in places, homogeneous black pigments in veins. They generally give no recognizable $\mathrm{X}$ ray reflections and are either amorphous or very poorly crystallized, like sea-floor Mn nodules. In cases where the material is sufficiently well crystallized to give recognizable $\mathrm{X}$-ray reflections, it invariably occurs distinctly below a cooling surface (at least a few centimeters), and the best crystallized material occurs well removed from cooling surfaces. Normally the assemblage includes both todorokite and birnessite. The todorokite presumably crystallized under nonoxidative conditions. The birnessite may, as argued above under nonoxidative diagenesis, form nonoxidatively in some cases. Generally, however, it is believed to be of oxidative diagenetic origin. Todorokite, where it coexists with the birnessite, is presumably armored and protected by birnessite, or else time and oxygen supply did not suffice to destroy it all. Birnessite without remnant todorokite was found in only two cases, both in thin cooling units: $319-13-1,88 \mathrm{~cm}$, and an uncertain sample in 320B-3-1, 119-124 cm. The rarity of birnessite without todorokite suggests that, at low temperatures, birnessite normally forms by oxidation of todorokite rather than by direct precipitation from solution (the opposite seems to be true under hydrothermal conditions; see discussion under nonoxidative diagenesis).

The rationalization of the above observations is, as with goethite, that the severity of nucleation-growth conditions at and very near cooling surfaces prevents formation of well-crystallized Mn oxides. At depth the processes occur at lower rates and better ordered crystals result.

\section{ARAGONITE-CALCITE RELATIONS}

An inquiry into natural calcium carbonates immediately leads one into the question of unstable and metastable compounds, of which discussions pertinent to the present problem have been given by Johnston et al. (1916) and Brooks et al. (1950). The following discussion draws heavily from the literature concerning diagenesis of carbonate sediments, to which the diagenetic veins are directly analogous except for the absence of skeletal carbonates and the metastable phases therein. The veins are of purely inorganic derivation and their behavior may in turn shed light on the origin of organic carbonate sediments in instances where the inorganic nature of certain minerals and processes is in question.

One of the first and most difficult problems encountered is the origin of the aragonite at Site 319 and any former aragonite that may have existed at the other sites. The usual discussion of this problem in the past has centered on stability relations extrapolated from high temperatures and pressures to room temperature, 1 atmosphere, and to surface seawater temperatures in tropical regions. Deep-sea carbonates, whether in sediments or in veins, lead one into a much colder realm where temperatures as low as $4^{\circ} \mathrm{C}$ may persist for geologically long times. In this realm we must consider the calcium carbonate hydrates which may form metastably when formation of calcite is inhibited (as by $\mathrm{Mg}^{+2}$ ) and may serve as precursors to unhydrated $\mathrm{CaCO}_{3}$ polymorphs. Of these, ikaite $\left(\mathrm{CaCO}_{3} \cdot 6 \mathrm{H}_{2} \mathrm{O}\right)$ is 
not stable at $25^{\circ} \mathrm{C}, 1$ atmosphere, nor at any other earthsurface condition, nor under deep-sea conditions $\left(4^{\circ} \mathrm{C}\right.$ and roughly 500 bars) (Van Valkenburg et al., 1971; Marland, 1975). Nonetheless, it has been synthesized at $-10^{\circ} \mathrm{C}$ (Brooks et al., 1950); $0^{\circ} \mathrm{C}$ (Johnston et al., 1916; Krauss and Schriever, 1930); and can be synthesized up to $27^{\circ} \mathrm{C}$ in the presence of $\mathrm{P}_{2} \mathrm{O}_{5}$ (Brooks et al., 1950). It decomposes rapidly only above $8^{\circ} \mathrm{C}$ (Krauss and Schriever, 1930), and, while it decomposes rapidly at $20^{\circ} \mathrm{C}$ in the presence of $\mathrm{Mg}$ ion, it can be preserved without decomposition for weeks in water at about $20^{\circ} \mathrm{C}$ in the presence of $\mathrm{P}_{2} \mathrm{O}_{5}$ (Brooks et al., 1950). Johnston et al. (1916) and Topley and Hume (1928) find that the synthetic hexahydrate decomposes above $0^{\circ} \mathrm{C}$ to calcite. Krauss and Schriever (1930) report decomposition begins at $8^{\circ} \mathrm{C}$ and yields calcite; they also report decomposition to the monohydrate at $28^{\circ} \mathrm{C}$. Brooks et al. (1950) find that it decomposes usually to calcite and vaterite, rarely to aragonite. Van Valkenburg et al. (1971) report that it decomposes to calcite, but P.M. Bell (personal communication, 1975) says that it sometimes decomposed to aragonite. Marland (1975) finds that it decomposes to calcite and, believing this to be the normal case, suggests (Marland, 1970) that hexahydrate nuclei are the precursors of calcite precipitation from solution. Collating these somewhat inconsistent, or, at any rate, complex reports, it appears that ikaite usually decomposes to calcite (or the monohydrate; Pauly, 1963) and is unlikely to be a precursor of the aragonite observed in the veins in Leg 34 basalts.

The data are even more conflicting as regards the monohydrate, $\mathrm{CaCO}_{3} \cdot \mathrm{H}_{2} \mathrm{O}$. Hull and Turnbull (1973) show that it is unstable at all temperatures at 1 atmosphere, and under all earth-surface conditions. Nonetheless, it has been synthesized at temperatures of about $-1^{\circ} \mathrm{C}$ (Brooks et al., 1950); forms in industrial air scrubbers at $10^{\circ}$ to $14^{\circ} \mathrm{C}$ (Marschner, 1969); and has been synthesized under a variety of calcite-inhibiting conditions at temperatures from $20^{\circ}$ to $28^{\circ} \mathrm{C}$ (Krauss and Schriever, 1930; Brooks et al., 1950; Baron and Pesneau, 1956; Monaghan and Lytle, 1956; Lippmann, 1959; van Tassel, 1962; Malone and Towe, 1970; Towe and Malone, 1970), and as high as $40^{\circ} \mathrm{C}$ (Brooks et al., 1950). From the industrial experience Marschner (1969) claims that it forms only at air-water interfaces, but others report it to form by dehydration of the hexahydrate (Krauss and Schriever, 1930); by aging of rapidly precipitated gels (Brooks et al., 1950; Baron and Pesneau, 1956; Monaghan and Lytle, 1956); on the walls of glass vessels (Lippmann, 1959); and in unspecified manner from solution (van Tassel, 1962; Malone and Towe, 1970; Towe and Malone, 1970). The precipitation from solution should not be taken necessarily to mean homogeneous nucleation because numerous interfaces were available to influence the process. The decomposition of the monohydrate occurs slowly. Brooks et al. (1950) were able to heat it to constant weight at $100^{\circ} \mathrm{C}$ to confirm its composition. They report that monohydrate vestiges remained after a year at $20^{\circ} \mathrm{C}$. The decomposition product is calcite or calcite plus aragonite. Krauss and Schriever (1930) report that it loses water "zeolitically," and is not fully dehydrated until $200^{\circ} \mathrm{C}$. The product is calcite. Marschner (1969) reports dry heating decomposition times of 13 days at $100^{\circ} \mathrm{C}, 100 \mathrm{~min}$ at $150^{\circ} \mathrm{C}$; decomposition in distilled water in 9 days; and no change in air-dried material and material under solution with less than 0.1 mole $\%$ of various inhibitors of decomposition $\left(\mathrm{MgCl}_{2}, \mathrm{BaCl}_{2}\right.$, calgon) in 3 months. On the other hand, certain additives, he finds, favor transformation $\left(\mathrm{NaCl}, \mathrm{NH}_{3}\right.$, $\mathrm{FeCl}_{2}$ ). He reports that dry heating yields calcite, and decomposition in the presence of water yields only aragonite, regardless of temperature or additive (except with dissolved $\mathrm{NH}_{3}$, when calcite forms).

From these various reports of relative stability, it is surprising that natural $\mathrm{CaCO}_{3} \cdot \mathrm{H}_{2} \mathrm{O}$ is reported from only two localities, a Russian and an Australian lake (see Hull and Turnbull, 1973). Marland (1970) concludes that the monohydrate decomposes to aragonite and suggests that monohydrate nuclei are precursors for the precipitation of aragonite. He intends this conclusion to pertain to behavior in aqueous solution. Extending his reasoning, we might suggest that the monohydrate is the precursor of aragonite in the veins in oceanic crustal basalts. A closer examination of the literature data provides arguments for and against this idea. Against it is Marschner's claim that the monohydrate forms only at air-water interfaces, but the various reports of its formation from solutions and gels clearly negate that claim as universally valid. Marschner concludes from the fact that $\mathrm{NaCl}$ favors the transformation to aragonite that the monohydrate is unlikely to form in seawater. On the other hand, van Tassel (1962) asserts that the neutral salts $\mathrm{MgCl}_{2}$ and $\mathrm{NaCl}$ favor the formation of the hydrate. Once formed, its decomposition would be favored by $\mathrm{NaCl}$ and inhibited by $\mathrm{MgCl}_{2}$. If it decomposed, it would yield aragonite. The absence of known marine occurrences is ambiguous as to whether it ever existed, and, if it did, the data given are in conflict as to the likelihood of its decomposition in seawater. Malone and Towe (1970) report that the monohydrate precipitated from seawater under the influence of bacterial action remained unaltered after 2 weeks. It is difficult and hazardous to extrapolate from such a short time base to survival probabilities on a geologic time scale. In summary, a $\mathrm{CaCO}_{3} \cdot \mathrm{H}_{2} \mathrm{O}$ precursor for the vein aragonite is neither favored nor excluded by the data at hand. Further investigation is indicated. Let it be clearly understood that the preceding discussion relates to a very early possible generation of calcium carbonate hydrates that slowly inverted to calcite and/or aragonite. The presently observed carbonates are relatively coarse grained and clear. They lack the white opacity due to microcracking that would be present if the hydrates existed immediately prior to coring and rapidly inverted during and immediately after coring to the much denser, unhydrated phases.

The most commonly assumed interpretation of a phase precipitated inorganically outside its field of stability is that nucleation of the stable phase is somehow inhibited and supersaturation levels requisite to nucleation of the metastable or unstable phase can be attained. This position has been invoked regarding polymorphs of $\mathrm{CaCO}_{3}$ by Johnston et al. (1916) and 
Brooks et al. (1950) and is implicit in many other papers. In contrast, Heffner and Gaines (1974) find that crystallization of calcite requires greater supersaturation than vaterite and aragonite. Evidently a great deal remains to be learned before these contradictions are resolved. The inhibition of calcite crystallization has been extensively studied in the laboratory and is ascribed most commonly to the effect of $\mathrm{Mg}^{+2}$. Among the more recent authors who suspected or drew this conclusion, we can cite Monaghan and Lytle (1956), who drew simply a general conclusion that $\mathrm{Mg}^{+2}$ inhibits calcite crystallization. Several authors specifically attribute the effect to inhibition of nucleation, among them being Simkiss (1964), who was not explicit as to the mechanism of inhibition, and Pytkowicz (1965), who suggested that $\mathrm{Mg}-\mathrm{CO}_{3}$ ion pair complexes enter the lattice and hinder its growth by causing an increase in the number of calcium carbonate collisions needed to overcome the hindrance and cause growth of stable nuclei. Lippmann (1960) and van Tassel (1962) invoked the high energy of hydration of $\mathrm{Mg}^{+2}$, such that $\mathrm{Mg}^{+2}$ ions in surface lattice sites block further growth until dehydration is effected. Berner (1967) discussed several possible mechanisms by which $\mathrm{Mg}$ inhibits growth of calcite nuclei. Bischoff (1968a) and Bischoff and Fyfe (1968) experimentally demonstrated, in studies of calcite nucleation in solutions equilibrated with aragonite, that the inhibiting effect of $\mathrm{Mg}$ is quite specific and that $\mathrm{Mg}$ is removed from solution into nuclei during the inhibition process. Normal growth occurs only when the $\mathrm{Mg}$ concentration is reduced below a certain level. Like Lippmann and van Tassel, Bischoff (1968b) attributes the inhibiting effect to hydration of the small $\mathrm{Mg}^{+2}$. Extrapolating from Bischoff's conclusions, we would expect to see an almost permanent inhibition of calcite growth during diagenesis of marine sediments until enough high-Mg calcite and other $\mathrm{Mg}$-bearing diagenetic minerals had formed to reduce the $\mathrm{Mg}$ to a very low level. Bischoff $(1968 \mathrm{a}, \mathrm{b})$ thus inferred that aragonite should first recrystallize to high-Mg calcite with an $\mathrm{MgCO}_{3}$ content lower than some value between 10 and 14 mole \%, and, indeed, magnesian calcite cements produced during marine diagenesis have been reported by Milliman (1966), Gevirtz and Friedman (1966), and Fischer and Garrison (1967). Berner (1974), stressing the uptake of $\mathrm{Mg}$ by calcite from solution, points out that the $\mathrm{Mg}$ thus inhibits, not only the nucleation, but also the growth of calcite because the resulting magnesian calcite is more soluble than pure calcite (Plummer and Mackenzie, 1974).

Katz (1973) demonstrates that the precipitation of calcite, as opposed to aragonite, is controlled, not by absolute concentrations, but by $\mathrm{Mg} / \mathrm{Ca}$. He concludes that calcite will not precipitate inorganically from seawater $(\mathrm{Mg} / \mathrm{Ca}=5.2)$ unless the $\mathrm{Mg} / \mathrm{Ca}$ is reduced to a value below about 2 or 2.2 (atomic ratio). His conclusion is consistent with the experimental results of Lippmann (1960) and van Tassel (1962). Katz derives partition coefficients of $\mathrm{Mg}$ between the calcite and water as a function of temperature, and these can be used (as they are below) to infer $\mathrm{Mg} / \mathrm{Ca}$ of the solutions from which magnesian calcites were precipitated. In anticipation, we note that the $\mathrm{Mg} / \mathrm{Ca}$ values derived do not violate the limits set by Katz. Katz drew, in addition, the important conclusion that, once the inversion of aragonite to calcite starts, it will go to completion because calcite takes up $\mathrm{Mg}$, whereas the $\mathrm{Mg}$-poor or $\mathrm{Mg}$-free aragonite releases only $\mathrm{Ca}$ to solution, so that $\mathrm{Mg} / \mathrm{Ca}$ in the solution continually decreases.

Leaving the specific question of the formation of aragonite, let us look at the question of the carbonates in veins and amygdules in a more general way. A synoptic view of those from Leg 34 basalts is given by Figure 7 , from which several important points may be gained. First, though, let me point out that the compositions are biased toward low values. Except for the two compositions determined by electron microprobe analysis, they were measured by the $d$-values of the (211) and (633) X-ray reflections using the curves of Goldsmith et al. (1958). Subsequently the writer found amended values given by Goldsmith et al. (1961) which indicate that a composition in Figure 7 at 10 mole $\% \mathrm{MgCO}_{3}$ would be about 1.5 mole \% too low, and less magnesian compositions would be low by proportionately smaller amounts, with no error at 0 mole \%. The systematic errors do not alter the interpretation below. The two microprobe values confirm that the major component beside $\mathrm{CaCO}_{3}$ is $\mathrm{MgCO}_{3}$, hence, that the $\mathrm{X}$-ray method of estimating composition is valid. Not included in Figure 7 are four values from the Experimental Mohole basalts which would plot at $15 \mathrm{~m} . \mathrm{y}$. or slightly less: 3.0 and 3.5 mole \% for two samples of conical crystals from vugs, and 4.0 and 5.0 mole \% for two veins in the basalt. Thus, they would not alter the distribution of compositions for Site 319, at which the basalts are of comparable age.

It is interesting that the maximum value falls in the range of $7 \%$ to $10 \% \mathrm{MgCO}_{3}$ predicted by Berner (1974) for extended growth of calcite in seawater, which suggests that the Mg-richest calcites grew from a medium near seawater in its composition. However, Berner's results are presumably for a temperature at or near $25^{\circ} \mathrm{C}$, whereas the vein calcites probably grew at or near $4^{\circ} \mathrm{C}$. Applying Katz's (1973) extrapolated partition coefficient for $4^{\circ} \mathrm{C}$, we get an $\mathrm{Mg} / \mathrm{Ca}$ much less than that of seawater. The coefficients for higher temperatures would give ratios deviating even more from that of seawater. It appears that the most magnesian Leg 34 calcite shown in Figure 7 grew under conditions not simulated by Berner's experiments.

At first glance, the envelope enclosing the left-hand extremes of the composition ranges shown (i.e., the low$\mathrm{Mg}$ ends) resembles a solvus, but it is a pseudosolvus since the vertical axis displays time, not temperature. The envelope more likely represents the progressive adjustment of early, metastable magnesian calcites toward the $\mathrm{Mg}$-poor compositions which are stable at about $4^{\circ} \mathrm{C}$ in the ambient fluids present. The excess $\mathrm{Mg}$ would presumably enter dolomite, of which none has been found by the writer in veins or interflow carbonates, but which does appear, presumably by a similar process, in overlying sediments (Bass, Rare Minerals in Sediments, this volume). The ultimately stable composition should be near pure calcite, but the process may go through 


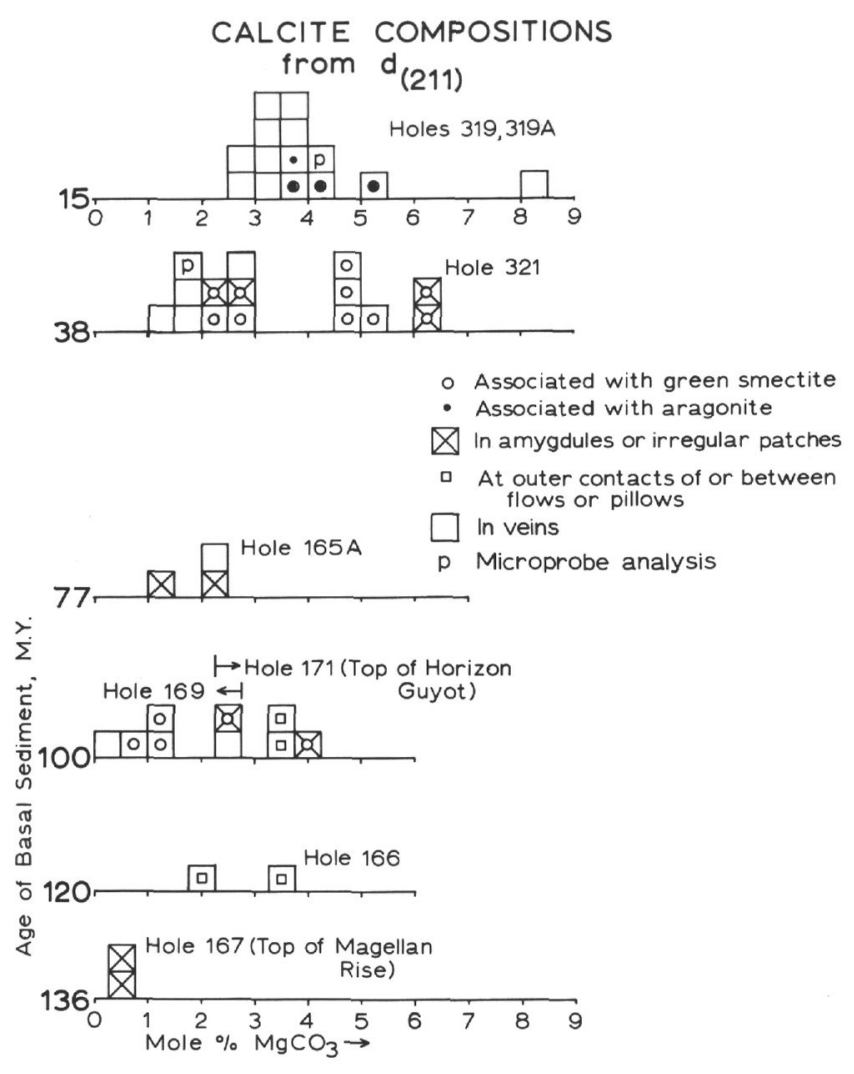

Figure 7. Compositions of secondary calcites from holes drilled during Legs 34 and 17, plotted versus age of basalt sediments. Ages are estimated from Berggren (1972). Four calcites from the Experimental Mohole, with a basal sediment age the same as or slightly less than that of Holes 319 and $319 \mathrm{~A}$, would not change the pattern shown for the calcites from those holes if they were included in the plot. Compositions are mainly from $d(211)$ and d(633) (Goldsmith et al., 1958), with two microprobe values (319-13, CC by L. J. Mazzullo; 32114-1, 11-15 cm by the writer). According to Goldsmith et al. (1961), the X-ray compositions shown are systematically low by an amount roughly proportional to the the $\mathrm{MgCO}_{3}$ content, the deficiency amounting to about 1.5 mole \% at 10 mole \% on the figure.

many intermediate metastable steps controlled by recrystallization in an $\mathrm{Mg}$-bearing pore fluid. The recrystallization probably occurs by solution and redeposition; solid-state diffusion is probably minor at low temperatures, as indicated by the very survival of the metastable magnesian calcites. The suggestion of intermediate compositional steps is supported by the range of compositions (from 1.6 to 2.4 mole \% total cations beside $\mathrm{Ca}$ ) found at different spots in the same vein by the microprobe analysis of 321-14-1, 11-15 cm; $\mathrm{X}$-ray analyses give average compositions for relatively large samples, for which the existence of ranges of compositions can be inferred only from peak widths. The progress of compositional adjustment may be irregular due to changes of fluid composition related to precipitation, solution, and alteration of primary and other secondary minerals and to influx of fluids from other environments by diffusion or by hydraulic flow in newly opened cracks. Thus, we might immediately conclude from the fact that the basalts and the overlying sediments are below the carbonate compensation depth (CCD) that this alone will promote solution. However, the CCD pertains to the open body of seawater itself and to the uppermost sediment layers. At greater subbottom depths the conditions governing the CCD no longer necessarily exist, as evidenced by the fact that calcite and aragonite deposition occurs at all.

The interpretation given above for the variations in Figure 7 , namely, secular readjustments to changing pore fluids, while undoubtedly in part correct, is not the whole story, as may be gathered from a closer inspection of the figure. The calcites from flow margins and interpillow spaces in Holes 166 and 171 tend toward high $\mathrm{MgCO}_{3}$ values and may reflect chemical environments different from those within the basalts themselves. Two of those interflow calcites are from Hole 171, at the top of Horizon Guyot, in which all calcites measured are fairly high in $\mathrm{MgCO}_{3}$, possibly because the sedimentary section is coarse-grained calcarenite and breccia through which seawater is able to flow relatively freely under the pressure gradients created by currents impinging on the sides of the guyot. Ignoring those unusual calcites, we see that, at any given site, calcites associated with green smectite and aragonite (nonoxidative diagenetic minerals) are more magnesian than the others, most or all of which are associated with oxidative diagenetic minerals. This correlation is more evident in the Leg 34 samples than in the older ones from Leg 17 because the Leg 17 rocks are almost all oxidatively altered. The data from Sites 319 and 321 clearly show that compositional adjustments related to oxidation are faster and more important than the secular adjustments related to time alone. The nature of the effects related to oxidative diagenesis is not certain, but several effects can be suggested.

First, oxidation reduces $p \mathrm{H}$ by means of two specific reactions, thus enhancing the solubility and recrystallization of carbonates. The first reaction is the oxidation of sulfides (Eq. 1 in the section above on oxidative diagenesis), which generates sulfuric acid. Such acid will be rapidly neutralized by reactions with silicates, carbonates, and oxides, and will thus influence only carbonates in the very near vicinity of the sulfides. The second reaction, which is of much greater importance in the present context, is the oxidation of ferrous $\mathrm{Fe}$ and manganous $\mathrm{Mn}$ in the calcite lattice itself, either or both of which are almost always present at low levels, as demonstrated by the microprobe analyses of the vein calcite from Site 321. The specific reaction is not known because of uncertainty as to the form in which the resulting ferric $\mathrm{Fe}$ is precipitated. Assuming a simple ferric hydroxide, the reaction is:

$$
\begin{gathered}
4 \mathrm{Fe}^{+2} \mathrm{CO}_{3}+\mathrm{O}_{2}+10 \mathrm{H}_{2} \mathrm{O}= \\
4 \mathrm{Fe}^{+3}(\mathrm{OH})_{3}+4 \mathrm{H}^{+}+4 \mathrm{HCO}_{3}-
\end{gathered}
$$

If such a reaction occurs in the intergranular fluid film between carbonate grains, both the reduction of free $\mathrm{H}_{2} \mathrm{O}$ and the increase of $\mathrm{H}^{+}$and $\mathrm{HCO}_{3}^{-}$(and $\mathrm{CO}_{3}=$ ) ions act to create a highly acid medium in which carbonate can readily dissolve and reprecipitate, thus tend- 
ing always to approximate local stable or metastable equilibrium. The actual acidity will vary with the forms in which the ferric $\mathrm{Fe}$ is precipitated (goethite, ferric hydroxide, amorphous hydrated oxide, hematite), which determine the amount of bound water. This can be important with the limited water available in a thin film.

A further effect, correlated with, but not directly due to, oxidation, is the fact that the advent of oxygen implies that fluids from sources external to the basalt (such as pore fluids from the overlying sediments) have arrived, either as such by hydraulic flow into open cracks, or in modified form by diffusion through a medium with which it progressively reacts. As summarized from much DSDP work by Sayles and Manheim (1975), these fluids have much lower $\mathrm{Mg} / \mathrm{Ca}$ than normal seawater due to precipitation of $\mathrm{Mg}$-rich diagenetic phases (silicates, magnesian calcite, and dolomite) and to release of $\mathrm{Ca}^{+2}$ from carbonate by exchange with $\mathrm{Mg}^{+2}$ from solution. They note an especially marked enrichment of $\mathrm{Ca}$ immediately above basalts, which they attribute to exchange of $\mathrm{Na}$ for $\mathrm{Ca}$ in silicates during "submarine weathering." Thus, interstitial fluids from the basal sediments, which are the ones most likely to diffuse or flow into the underlying basalts, have the lowest $\mathrm{Mg} / \mathrm{Ca}$. They will stabilize $\mathrm{Mg}$-poorer calcites and aid the readjustments inferred from Figure 7 . It was remarked above that influx of sedimentary pore fluids might also transpose surface and near-surface solution chemistry to the interiors of cooling units in such a manner as to account for the sporadic interior occurrences of phillipsite. That phillipsite tends to be associated with late calcite assigned to the stage of oxidative diagenesis. They may owe their existence to the influx of the same fluids.

On the basis of the preceding discussion, the writer proposes the following integrated history of diagenetic carbonates in the Leg 34 basalts. He attempts to relate the carbonates to other simultaneously formed minerals, drawing on observations scattered through the earlier part of this paper. It is well to remind the reader at this point of one of those observations and its implications. The aragonite from Site 319 is fresh, showing no evidence for solution or etching. In view of Katz's (1973) demonstration that inversion of aragonite, once started, will go to completion, we must conclude that the magnesian calcite associated with the aragonite did not form by inversion of aragonite at all, or else by total inversion of a wholly independent, earlier generation of aragonite. From this we conclude further that magnesian calcite associated with aragonite is paragenetically earlier than the aragonite.

Thus, once a basalt is cooled and enters the regime of nonoxidative diagenesis, $\mathrm{Mg}$ and other constituents from the alteration of olivine and intersertal glass enter the pore fluids. The precipitation of green and bluegreen, saponitic smectite keeps the $\mathrm{Mg} / \mathrm{Ca}$ of the solution down, and $\mathrm{Ca}$ released by alteration is precipitated as magnesian calcite as carbonate ions diffuse in from the pore fluids in the overlying sediments. The $\mathrm{MgCO}_{3}$ content of the magnesian calcites varies, either regularly or irregulary, through a finite range. The present range inferred from Figure 7 is 2 to 6.5 mole $\% \mathrm{MgCO}_{3}$ at Sites 319 and 321 , though the original range may have been perturbed toward lower values due to later adjustments toward more stable low-Mg calcites. Accepting the empirical range of compositions, and applying the partition coefficient of 0.038 found by extrapolating Katz's (1973) curve to $4^{\circ} \mathrm{C}$, we infer a range of $\mathrm{Mg} / \mathrm{Ca}$ from 0.6 to 2.1 in the pore fluids, in accord with Katz's limit of 2.2 for calcite nucleation. Winland's (1969) partition coefficient of 0.02 , derived from carbonates which underwent diagenesis at $20^{\circ} \mathrm{C}$, would give a range of $\mathrm{Mg} / \mathrm{Ca}$ in the solutions from 1.2 to 4.1 , and is clearly not applicable to deep-sea diagenesis; very likely the value is wrong, as argued by Katz. With the progress of nonoxidative alteration of the basalt, the readily altered phases olivine and intersertal glass rapidly diminish and the supply of $\mathrm{Mg}$ ions and other constituents to pore fluids dwindles accordingly. The relative proportions of these constituents remaining in the pore fluids are not the same as the proportions in which they were consumed by the diagenetic silicates. Instead, as the formation of the silicates slows or effectively halts, $\mathrm{Mg}$ is left in excess, perhaps because the Fe-richer primary phases have altered faster than the $\mathrm{Mg}$-richer ones. At any rate, the $\mathrm{Mg} / \mathrm{Ca}$ of the pore fluids increases, the $\mathrm{MgCO}_{3}$ content of the calcites increases, and calcite nucleation is ultimately halted. The most magnesian calcite observed should thus have been the last to form, and, applying Katz's coefficient of 0.038 , we find $\mathrm{Mg} / \mathrm{Ca}=2.9$ in the solution from which the last magnesian calcite precipitated during nonoxidative diagenesis (10 mole $\% \mathrm{MgCO}_{3}$, obtained by applying the correction from Goldsmith et al., 1961; Winland's coefficient of 0.02 would give $\mathrm{Mg} / \mathrm{Ca}=5.6$ ). At this time, the presently observed aragonite begins to form, perhaps with a time lapse after cessation of calcite formation if the $\mathrm{Ca}$ or carbonate concentration has to be built up so that the solubility product of aragonite is exceeded. The last-formed smectite is probably $\mathrm{Mg}$ richer than that formed earlier, and the increased $\mathrm{Mg} /$ (total cations) in solution may be the underlying reason for the increase of diagenetic chlorite toward the presumably late-formed centers of zoned smectite veins. The high $\mathrm{Mg}^{+2}$ in the late solutions may also lead to exchange with other ions, presumably alkalis, in the interlayer positions of smectites formed in or exposed to the late solutions. This may explain the low exchangeable alkali content found from the calculated structural formula of the analyzed smectite (see above under nonoxidative diagenesis), from which the writer inferred, as one possibility, that some of those sites are occupied by $\mathrm{Mg}$. The diagenetic chlorite contamination in the analyzed smectite is consistent with this inference. The conditions which led to deposition of aragonite, chlorite, and Mg-rich smectite presumably continue to this day, and the writer's suggested history can be checked if the pore waters in the basalts can ever be sampled and analyzed.

With the influx or inward diffusion of oxygen and fluids with low $\mathrm{Mg} / \mathrm{Ca}$ from the interflow and intrasedimentary pores, aragonite-forming conditions again gave way to calcite-forming conditions. Red-pigmented calcites were deposited directly from solution or formed by inversion of aragonite. Instances like that illustrated in Figures $6 \mathrm{c}$ and $6 \mathrm{~d}$ show that smectite was oxidized faster than the inversion of aragonite, either because of the relative kinetics of the two processes or because ox- 
ygen supply arrived faster than a significant reduction of $\mathrm{Mg} / \mathrm{Ca}$ in those cases (presumably the most numerous) where these constituents arrived by molecular diffusion. The further progress of the changes can perhaps be inferred from the calcites observed in older rocks cored during Leg 17 (Figure 7).

Granting the history just outlined, we can approach a problem first noted by Bass et al. (1973a, b), but not discussed in any detail because of its totally perplexing nature. This is the nonrandom distribution of calcite in the basalts. In virtually all altered deep-sea basalts the secondary carbonate is generally not uniformly distributed, even in relatively small volumes, throughout the body of the rock from which the $\mathrm{Ca}$ and $\mathrm{Mg}$ in the carbonate were derived. Instead, it is found in veins and amygdules, as if, for some reason, the calcite could nucleate and/or grow only in relatively large voids. In the veins the carbonate may be accompanied by smectite, but they are not mixed on an intimate scale, rather separated in large lenses. In amygdules, any smectite present lines the walls of the former vesicles and the carbonate, always calcite in the writer's experience, with but one exception, occupies the centers. If sulfide is present, it is at or very near the outer surface of the calcite, in contact with the smectite fringe, where present. Thus, the nonoxidative diagenetic assemblage smectite-sulfide seems to have formed before calcite deposition in the amygdules, and perhaps in the veins as well. The $\mathrm{MgCO}_{3}$ content of the amygdular calcite is varied, as a glance at Figure 7 will show.

A further peculiarity of carbonate deposition showed up most strikingly in the basalts from Hole 171, drilled on top of Horizon Guyot in the Mid-Pacific Mountains. There, the calcite occupies both veins and amygdules, but the amygdules are restricted to the interiors of blocks outlined by the veins, whereas the edges of those blocks, immediately adjacent to the veins, are free of calcite amygdules (Figure 8a, b). A variant on this theme is seen in $321-14-2,19-29 \mathrm{~cm}, 37-41 \mathrm{~cm}$, and $42-54 \mathrm{~cm}$, where smectite or sulfide veins are flanked by vesicles which are either empty or lined by blue smectite or rarely drusy sulfide (it is conceivable but unlikely that the vesicles were once filled by calcite or smectite amygdules which were plucked out during sawing since some smectite-lined ones have a few drusy calcite crystals on their walls), whereas vesicles removed from the veins by roughly a centimeter or more are filled with calcite. In the Leg 17 rocks (Hole 171), the calcite-free zones may in part be due to the absence of vesicles if the veins occupy primary cooling cracks near which the remaining interstitial magma in the almost-crystallized rocks was degassed. However, this is not always the case since some calcite-free zones contain smectite amygdules and the calcite-free zones in the rocks from Site 321 contain smectite-lined vesicles.

Since the calcite amygdules were deposited after termination of deposition of nonoxidative smectite and sulfide, the carbonate may belong to the late nonoxidative or oxidative stage of diagenesis. The presence of green smectite and sulfide eliminates the oxidative stage, so the calcite is probably of late nonoxidative diagenetic origin. It may be contemporaneous with the late magne-
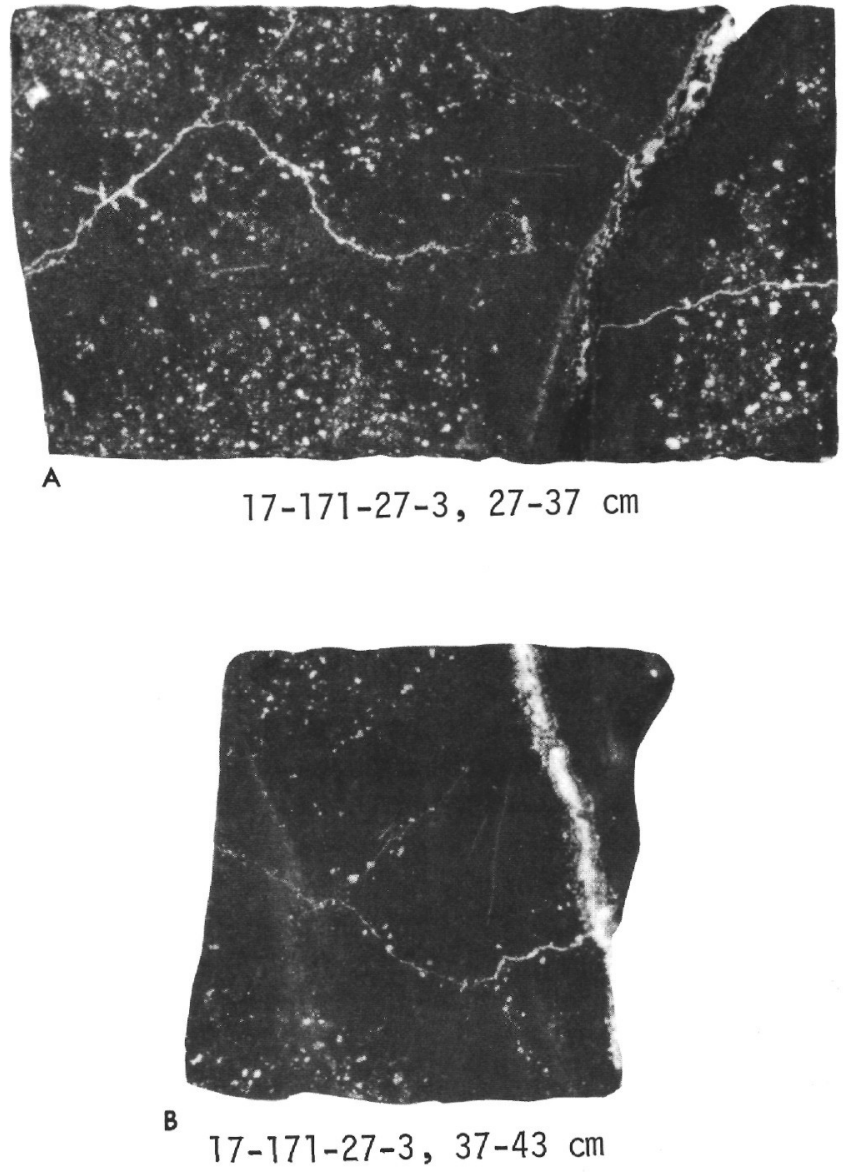

Figure 8. Slices through the interior of a large pillow cored during Leg 17 in Hole 171 on top of Horizon Guyot in the Mid-Pacific Mountains. They illustrate a strong preferred deposition of calcite in large voids (vesicles and veins), in contrast to that of smectite which is found, not only in veins and vesicles, but also throughout the solid rock matrix from which the Ca for the calcite was presumably derived (see Bass et al., 1973a, p. 500, for more details). They also show a strong tendency for the absence of calcite amygdules in the areas immediately flanking veins, which, in this case, contain both calcite and smectite. Smectite amygdules are present in the areas devoid of calcite amygdules. The narrow calcite vein in the right center of Figure 8 is an exception in that it lacks calcitefree border; it may represent the filling of a late crack opened after the surrounding calcite amygdules had been deposited.

sian calcite in the veins, it may represent the only carbonate deposited in the possible carbonate-free interval in the veins when neither magnesian calcite nor aragonite was being deposited, or it may be contemporaneous with the aragonite. The finely crystalline, radial structure of the amygdules does not exclude the possibility that they are magnesian calcite inverted from original aragonite. If so, it formed in fluids of high $\mathrm{Mg} / \mathrm{Ca}$ and later inverted when that ratio fell to a low value. If, as seems more likely, the amygdules were originally calcite, then they grew in areas of low $\mathrm{Mg} / \mathrm{Ca}$. In the rocks from Hole 171 (Figure 8), the low-Mg/Ca 
fluids were present in both vesicles and veins. In the rocks from Hole 321, the veins and nearby vesicles had fluids with high $\mathrm{Mg} / \mathrm{Ca}$ which inhibited calcite deposition (they are presently devoid of carbonate). The more distant vesicles, now filled with calcite, had low $-\mathrm{Mg} / \mathrm{Ca}$ fluids, and the concentration gradient for $\mathrm{Ca}$ set up by precipitation of calcite within them guaranteed that no carbonate, even aragonite, was deposited in the veins.

The reason for the low $\mathrm{Mg} / \mathrm{Ca}$ in fluids filling large pores is not clear. Three reasons can be suggested: (1) smectite deposition; (2) low supply of $\mathrm{Mg}$; and (3) the supply of $\mathrm{Mg}$ to large fluid masses in megapores was not high enough to raise $\mathrm{Mg} / \mathrm{Ca}$ to a level that would inhibit calcite nucleation. Regarding reason 1, smectite deposition would not seem adequate since all of the calcite is postsmectite in the amygdules. Reason 2 is plausible if the calcite was deposited after all readily altered material in the basalt host was already destroyed, hence little new $\mathrm{Mg}$ was being supplied, and any that still existed in solution was diffusing out (or had already diffused out) of the vesicles along gradients set up by precipitation of $\mathrm{Mg}$-bearing phases elsewhere in the basalt or even outside of it. Reason 3 is plausible if the fluids filling the pores were largely derived from the overlying sediments and arrived with low $\mathrm{Mg} / \mathrm{Ca}$. They may then never have become significantly richer in $\mathrm{Mg}$ because the rate of supply of $\mathrm{Mg}$ was slow enough relative to the rate of formation of $\mathrm{Mg}$-bearing phases, such as smectite, that large masses of free fluid always remained relatively dilute. In thin, intergranular films, on the other hand, the same supply and precipitation rates may have produced relatively concentrated brines. If, coupled with this $\mathrm{Mg}$ budget, the rate of supply of carbonate ions was so low that the solubility product of neither calcite nor aragonite was exceeded, $\mathrm{Ca}$ freed by alteration of primary silicates and intersertal glass would build up in both bulk fluid masses in megapores and fluid films between grains, thereby helping create and maintain low $\mathrm{Mg} / \mathrm{Ca}$. If the late-arriving carbonate ions diffused preferentially into the larger fluid masses and calcite precipitation began there, the resulting concentration gradients would constrain all available $\mathrm{Ca}$ and carbonate ions to continue migrating there if the diffusion coefficients for these ions were high enough. The explanations for the abundance and distribution of $\mathrm{Mg}$ and $\mathrm{Ca}$ in this third possible explanation of the low$\mathrm{Mg} / \mathrm{Ca}$ fluids are plausible, but the explanation for the carbonate ions is weak. It is not clear why the ions should diffuse preferentially into vesicles far removed from veins when the veins should be the preferred paths. Then, even if there were no space for carbonate deposition in the veins, the nearest vesicles should be the loci of initiation of calcite deposition, not the ones furthest removed.

In conclusion, the writer does not equate his discussion with an answer to the problem of selective occurrence of carbonates in megapores, but he hopes that his pointing out the problem will stimulate further work and thought by those who find similar distributions.

\section{CONCLUSIONS}

Four stages of formation of secondary minerals can be distinguished in oceanic basalts. The early part of the first stage, at high temperature, is the crystallization of late magmatic minerals, including biotite, iddingsite, and ilmenite lamellae in titanomagnetite oxidized at high temperature. Those minerals were followed closely by deuteric chlorite and kaolinite(?), and possibly quench smectite and hydrothermal smectite.

The outer surfaces of the cold, unburied basalts experienced the second stage when exposed to oxygenated bottom waters. The most prominent product of this stage is palagonite. Others include earthy $\mathrm{Fe}$ oxide pseudomorphs after olivine, and golden yellow to brown palagonite and poorly crystallized smectite after intersertal, near-surface glass. The seawater alteration which occurs in near-surface, but not completely exposed rocks during this stage is closely akin to nonoxidative and oxidative diagenesis (third and fourth stages) because the initial alteration in the absence of oxygen gives way to radically different effects when oxygen arrives later. Therefore, these effects could just as logically have been ascribed to the third and fourth stages.

The third and fourth stages are diagenesis in the strict sense, comprising the total time during which postburial effects developed before and after the arrival of oxygen. The oxygen diffuses into the basalt from the bottom water through the interstitial fluids of the sediments (which are almost wholly oxidized and retard the oxygen front little or not at all).

The third stage is referred to as "nonoxidative" diagenesis, a misnomer in the strict sense in that the range of oxidation states of the nonoxidatively altered basalts indicates that some oxidation occurred. The main distinguishing feature is the absence of independent, highly colored ferric Fe compounds, so that the nonoxidatively altered basalts are dominantly gray, and the veins are green, blue-green, and gray. Among primary phases, olivine is altered to green smectite plus minor carbonate, talc, and, given a supply of $\mathbf{K}$, traces of mica. Intersertal glass is altered to green smectite (though some of the smectite observed may be an earlier quench product). The major vein minerals are green saponitic smectite, magnesian calcite, aragonite, pyrite, and marcasite, with lesser mica (celadonite), chlorite, talc, and phillipsite, and possibly traces of quartz, todorokite, and birnessite. Mobile elements were $\mathrm{Ca}$, $\mathrm{Mg}, \mathrm{Fe}, \mathrm{Al}, \mathrm{Si}, \mathrm{Mn}, \mathrm{S}$, and $\mathrm{K}$. All one-, two-, and threephase phyllosilicate assemblages in the veins can be portrayed in the modified AKF diagram $\left(\mathrm{Al}, \mathrm{Fe}^{+3}\right)-(\mathrm{K}, \mathrm{Na}$, $\mathrm{Ca})-\left(\mathrm{Fe}^{+2}, \mathrm{Mg}\right)$ in a manner consistent with phase-rule constraints, thus suggesting that the veins are metastable or quasi-equilibrium assemblages. The RML phases chlorite-smectite and mica-smectite are not readily included in the quasi-equilibrium scheme. A limited supply of dissolved $\mathrm{Si}$ seems to have restricted the abundances of siliceous phases like celadonite and talc. Quartz is rare. Magnesian calcite nucleation was possible because smectite crystallization held the atomic ratio $\mathrm{Mg} / \mathrm{Ca}$ of pore fluids to values below about 2.2. When the balance of supply of necessary constituents led to the slowing or halting of smectite crystallization, $\mathrm{Mg} / \mathrm{Ca}$ rose and aragonite crystallization superseded that of calcite. The aragonite may be contemporaneous with late $\mathrm{Mg}$-rich chlorite and smectite. The source of sulfur 
for pyrite and marcasite is unknown. The coexistence of the two polymorphs(?) may be a consequence of diagenesis at temperatures as low as $4^{\circ} \mathrm{C}$, which have not been experimentally investigated in aqueous sulfide and most aqueous silicate systems. Nonoxidative phillipsite is rare, evidently because nonoxidative alteration is most commonly preserved intact in the interiors of thick cooling units where phases better able than phillipsite to incorporate the available $\mathrm{Si}$ and $\mathrm{K}$ crystallize. Nonoxidative todorokite and especially birnessite are much better crystallized than Mn oxides at the surfaces of the cooling units and in ordinary $\mathrm{Mn}$ nodules, presumably because of slow crystallization in the interiors of the cooling units.

The final phase of secondary alteration is marked by the appearance of independent ferric Fe phases, such as goethite, hematite, and various "limonite" stains. While the changes coincide with an increase in the intensity of oxidation, and presumably an increased supply of ferric $\mathrm{Fe}$, the independent phases are at least in part due to cessation of formation of other phases that compete for Fe. The only phyllosilicate that seems to have formed under oxidative conditions is celadonite. Smectite, chlorite, and talc ceased crystallizing. The nonoxidative smectite, upon oxidation, turns colorless and expels $\mathrm{Fe}$ as $\mathrm{Fe}$ oxide dust which pigments the new smectite. The details of chlorite oxidation are not known, but ultimately it and smectite may even be destroyed. Olivine which survived nonoxidative alteration is replaced by earthy $\mathrm{Fe}$ oxides, just as in the earlier, preburial, seawater alteration. Titanomagnetite is oxidized progressively through titaniferous maghemomagnetites toward maghemite. Plagioclase and clinopyroxene remain relatively stable except for the outermost, Ferichest parts of zoned pyroxenes. Extensive alteration of pyroxene does not appear except in rocks much older than those recovered during Leg 34, and then only, or especially, in the presence of high activities of the various carbonate ion species.

Relatively Mg-poor calcite crystallizes during oxidative diagenesis directly from solution, by inversion of aragonite, and by reequilibration of relatively $\mathrm{Mg}$-rich calcite. The reequilibration (solution and redeposition) may be aided by carbonic acid generated during the oxidation of the ferrous $\mathrm{Fe}$ and manganous $\mathrm{Mn}$ components of the calcites.

Sulfides are oxidized and the sulfate is lost, thus leading to the radical reduction of $S$ in rocks which have undergone oxidative diagenesis. The products peculiar to oxidative diagenesis, namely goethite ("limonite") and birnessite, are poorly crystallized or amorphous at and close to the surfaces of cooling units where the effects of oxidation are so intense that either nuclei cannot form, or else they form so rapidly that none can grow significantly. Toward interior reaches of cooling units, better crystallized goethite and birnessite occur, reflecting less severe conditions. Locally hematite forms, either directly or by the aging of goethite. Todorokite is not an oxidative diagenetic mineral and survives only where armored by the birnessite or amorphous Mn oxides to which it is altered.

Phillipsite is insensitive to oxidation but occurs most abundantly on palagonite or in oxidatively altered, nearsurface rocks. The reason is believed to be that phillip- site does not compete well for $\mathrm{Si}$ with the nonoxidative minerals which form in the interior, so it crystallizes on and near glass or former glass where Si (and K) are available, and, due to the oxidative conditions, the competing nonoxidative phases cannot form.

\section{ACKNOWLEDGMENTS}

The writer is indebted to the Department of Terrestrial Magnetism for the support, encouragement, and office facilities that enabled him to devote most of a year to this work. To the Deep Sea Drilling Project, at every level, he simply says "thanks" for the opportunity to join a great adventure. He cannot speak too highly of the technical staff aboard Glomar Challenger that patiently and repeatedly reopened sealed cores for him and photographed and sectioned them at his request. The members of the scientific party endured the lengthy tie-up of cores necessary to the study and sampling which underlie this paper, and then generously discussed their own results in response to the writer's inquiries. He especially benefited from discussions with S.R. Hart, R.S. Yeats, J.M. Ade-Hall, and T.L. Vallier. The laboratory work and mineral separations ashore were done at the Geophysical Laboratory. The writer thanks H.S. Yoder, Jr. (Director), T.C. Hoering, and G.L. Davis for the use of various facilities and space, and especially P.M. Bell for the use of his laboratory and an X-ray diffractometer, and for introducing him to ikaite and its significance. The diffractometer functioned faithfully and well under the care of C.G. Hadidiacos. D. Virgo kindly measured $\mathrm{Fe}^{+3} / \mathrm{Fe}^{+2}$ in several minerals by Mössbauer spectroscopy. L.J. Mazzullo supplied a microprobe analysis of a vein calcite. The Lunar Science Institute provided some drafting and photographic facilities and services. Finally, sincere thanks are extended to S.R. Hart for his multiple roles as comrade, colleague, and advisor.

\section{REFERENCES}

Allen, E.T., Crenshaw, J.L., and Merwin, H.E., 1914. Effect of temperature and acidity in the formation of marcasite $\left(\mathrm{FeS}_{2}\right)$ and wurtzite $(\mathrm{ZnS})$; a contribution to the genesis of unstable forms: Am. J. Sci., v. 38, 4th ser., p. 393-431.

Baron, G. and Pesneau, M., 1956. Sur l'existence et un mode de préparation du monohydrate de carbonate de calcium: C.R. Acad. Sci. Paris, v. 243, p. 1217-1219.

Bass, M.N., 1974. Secondary minerals in basalt, DSDP Leg 34: Geol. Soc. Am., Abstracts with Programs, v. 6, p. 646.

Bass, M.N., Moberly, R., Rhodes, J.M., Shih, C.S., and Church, S.E., 1973a. Volcanic rocks cored in the central Pacific, Leg 17, Deep Sea Drilling Project. In Initial Reports of the Deep Sea Drilling Project, Volume 17: Washington (U.S. Government Printing Office), p. 429503.

1973b. Volcanic rocks cored in the central Pacific, Leg 17, Deep Sea Drilling Project: Am. Geophys. Union Trans., v. 54, p. 991-995.

Berggren, W.A., 1972. A Cenozoic time-scale-some implications for regional geology and paleobiogeography: Lethaia, v. 5, p. 195-215.

Berner, R.A., 1967. Comparative dissolution characteristics of carbonate minerals in the presence and absence of aqueous magnesium ion: Am. J. Sci., v. 265, p. 45-70.

1974. The role of magnesium in the crystal growth of calcite and aragonite from sea water: Geol. Soc. Am., Abstracts with Programs, v. 6, p. 653-654.

Bischoff, J.L., 1968a. Catalysis, inhibition, and the calcitearagonite problem II. The vaterite-aragonite transformation: Am. J. Sci., v. 266, p. 80-90.

1968b. Kinetics of calcite nucleation: magnesium ion inhibition and ionic strength catalysis: J. Geophys. Res., v. 73, p. 3315-3322. 
Bischoff, J.L. and Fyfe, W.S., 1968. Catalysis, inhibition, and the calcite-aragonite problem I. The aragonite-calcite transformation: Am. J. Sci., v. 266, p. 65-79.

Boettcher, A.L. and Wyllie, P.J., 1967. Biaxial calcite inverted from aragonite: Am. Mineral., v. 52, p. 1527-1529.

Brew, D.A. and Muffler, L.J.P., 1965. Upper Triassic glass from Hound Island, Keku Strait, southeastern Alaska: U.S. Geol. Surv. Prof. Paper 525-C, p. C38-C43.

Brooks, R., Clark, L.M., and Thurston, E.F., 1950. Calcium carbonate and its hydrates: Phil. Trans. Roy. Soc. London, Ser. A, v. 243, p. 145-167.

Buerger, M.J., 1934. The pyrite-marcasite relation: Am. Mineral., v. 19 , p. 37-61.

Cooper, L.H.N., 1938. Some conditions governing the solubility of iron: Roy. Soc. London Proc., Ser. B, v. 124 p. 299-307.

Fischer, A.G and Garrison, R.E., 1967. Carbonate lithification on the sea floor: J. Geol., v. 75, p. 488-496.

Friedman, I., Smith, R.L., and Long, W.D., 1966. Hydration of natural glass and formation of perlite: Geol. Soc. Am. Bull., v. 77, p. 323-327.

Garrels, R.M., and Christ, C.L., 1965. Solutions, minerals, and equilibria: New York (Harper \& Row).

Gevirtz, J.L. and Friedman, G.M., 1966. Deep-sea carbonate sediments of the Red Sea and their implications on marine lithification: J. Sediment. Petrol., v. 36, p. 143-151.

Goldsmith, J.R., Graf, D.L., Chodos, A.A., joensuu, O.I., and McVicker, L.D., 1958. Relation between lattice constants and composition of the $\mathrm{Ca}-\mathrm{Mg}$ carbonates: $\mathrm{Am}$. Mineral., v. 43, p. 84-101.

Goldsmith, J.R., Graf, D.L., and Heard, H.C., 1961. Lattice constants of the calcium-magnesium carbonates: Am. Mineral., v. 46, p. 453-457.

Hanor, J.S., 1971. Vein manganese from the deep ocean floor: Geol. Soc. Am., Abstracts with Programs, v. 3, p. 590 .

Harder, H., 1971. Quartz and clay mineral formation at surface temperature: Mineral. Soc. Japan Spec. Paper 1, p. 106-108.

1973. Synthese von eisenhaltigen Tonmineralen bei niedrigen Temperaturen: Naturwissenschaften, v. 11, p. 517.

Heffner, J.D. and Gaines, A.M., 1974. Metastable precipitation of aragonite. Geol. Soc. Am., Abstracts with Programs, v. 6, p. $787-788$.

Hemley, J.J., 1959. Some mineralogical equilibria in the system $\mathrm{K}_{2} \mathrm{O}-\mathrm{Al}_{2} \mathrm{O}_{3}-\mathrm{SlO}_{2}-\mathrm{H}_{2} \mathrm{O}$ : Am. J. Sci., v. 257, p. 241270.

Hemley, J.J. and Jones, W.R., 1964. Chemical aspects of hydrothermal alteration with emphasis on hydrogen metasomatism: Econ. Geol., v. 59, p. 538-569.

Hull, H. and Turnbull, A.G., 1973. A thermochemical study of monohydrocalcite: Geochim. Cosmochim. Acta, v. 37 p. 685-694.

Johnston, J., Merwin, H.E., and Williamson, E.D., 1916. The several forms of calcium carbonate: Am. J. Sci., 4th ser., v. 41 , p. $473-512$.

Katz, A., 1973. The interaction of magnesium with calcite during crystal growth at $25-90^{\circ} \mathrm{C}$ and one atmosphere: Geochim. Cosmochim. Acta, v. 37, p. 1563-1586.

Kempe, D.R.C., 1974. The petrology of the basalts, Leg 26. In Initial Reports of the Deep Sea Drilling Project, Volume 26: Washington (U.S. Government Printing Office), p. 465-503.

Krauss, F. and Schriever, W., 1930. Die Hydrate des Calciumcarbonats: Z. Anorg. Allgem. Chem., v. 188, p. 259-273

Kullerud, G., 1967. Sulfide studies. In Abelson, P.H. (Ed.), Researches in Geochemistry: New York (Wiley), p. 286321 .
Lippmann, F., 1959. Darstellung und kristallographische Daten von $\mathrm{CaCO}_{3} \cdot \mathrm{H}_{2} \mathrm{O}$ : Naturwiss., v. 46, p. 553-554. 1960. Versuche zur Aufklärung der Bildungsbedingungen von Calcit and Aragonit: Fortschr. Min., v. 38 , p. $156-161$.

Malone, P.G. and Towe, K.M., 1970. Microbial carbonate and phosphate precipitates from sea water cultures: Marine Geol., v. 9, p. 301-309.

Marland, G., 1970. Precursors to calcite and aragonite precipitation: Am. Geophys. Union Trans. (EOS), v. 51, p. 831 .

1975. The stability of $\mathrm{CaCO}_{3} \cdot 6 \mathrm{H}_{2} \mathrm{O}$ (ikaite): Geochim. Cosmochim. Acta, v. 39, p. 83-91.

Marschner, $\mathrm{H} ., 1969$. Hydrocalcite $\left(\mathrm{CaCO}_{3} \cdot \mathrm{H}_{2} \mathrm{O}\right)$ and nesquehonite $\left(\mathrm{MgCO}_{3} \cdot 3 \mathrm{H}_{2} \mathrm{O}\right)$ in carbonate scales: Science, v. 165 , p. $1119-1121$.

Milliman, J.D., 1966. Submarine lithification of carbonate sediments: Science, v. 153, p. 994-997.

Monaghan, P.H. and Lytle, M.L., 1956. The origin of calcareous ooliths: J. Sediment. Petrol., v. 26, p. 111-118.

Moore, J.G., 1965. Petrology of deep-sea basalt near Hawaii: Am. J. Sci., v. 263, p. 40-52.

1966. Rate of palagonitization of submarine basalt adjacent to Hawaii: U.S. Geol. Surv. Prof. Paper 550-D, p. D163-D171.

Moore, J.G., Phillips, R.L., Grigg, R.W., Peterson, D.W., and Swanson, D.A., 1973. Flow of lava into the sea, 19691971, Kilauea Volcano, Hawaii: Geol. Soc. Am. Bull., v. 84 , p. $537-546$.

Muffler, L.J.P., Short, J.M., Keith, T.E.C., and Smith, V.C., 1969. Chemistry of fresh and altered basaltic glass from the Upper Triassic Hound Island Volcanics, southeastern Alaska: Am. J. Sci., v. 267, p. 196-209.

Murata, K.J., Bastron, H., and Brannock, W.W., 1965. X-ray determinative curve for Hawaiian olivines of composition F076-88: U.S. Geol. Surv. Prof. Paper 525-C, p. 35-37.

Pauly, H., 1963. Ikait, nyt mineral der danner skaer: Naturens Verden, v. 46 , p. 2-12.

Peterson, M.N.A., 1962. The mineralogy and petrology of upper Mississippian carbonate rocks of the Cumberland Plateau in Tennessee: J. Geol., v. 70, p. 1-31.

Plummer, L.N. and Mackenzie, F.T., 1974. Predicting mineral solubility from rate data: application to the dissolution of magnesian calcites: Am. J. Sci., v. 274, p. 61-83.

Pytkowicz, R.M., 1965. Rates of inorganic calcium carbonate nucleation: J. Geol., v. 73, p. 196-199.

Rex, R.W., 1967. Authigenic silicates formed from basaltic glass by more than 60 million years' contact with sea water, Sylvania Guyot, Marshall Islands: Clay Clay Minerals, Proc. 15th Conf., p. 195-203.

Ridley, W.I., Rhodes, J.M., Reid, A.M., Jakes, P., Shih, C., and Bass, M.N., 1974. Basalts from Leg 6 of the Deep-Sea Drilling Project: J. Petrol., v. 15, p. 140-159.

Rosenthal, G., 1956. Versuche zur Darstellung von Markasit, Pyrit und Magnetkies aus wässrigen Lösungen bei Zimmertemperatur: Heidelberger Beitr. Min. Petrog., v. 5, p. 146164.

Ross, C.S. and Hendricks, S.B., 1941. Chemical composition and genesis of glauconite and celadonite: Am. Mineral., v. 26 , p. 683-708.

Ross, C.S. and Hendricks, S.B., 1945. Minerals of the montmorillonite group, their origin and relation to soils and clays: U.S. Geol. Surv. Prof. Paper 205-B, p. 23-79.

Sayles, F.L. and Manheim, F.T., 1975. Interstitial solutions and diagenesis in deeply buried marine sediments: results from the Deep Sea Drilling Project: Geochim. Cosmochim. Acta, v. 39, p. 103-127.

Scott, M.R., Scott, R.B., Nalwalk, A.T., Rona, P.A., and Butler, L.W., 1973. Hydrothermal manganese in the Me- 
dian Valley of the Mid-Atlantic Ridge: Am. Geophys. Union Trans. (EOS), v. 54, p. 244.

Scott, R.B., Scott, M.R., Swanson, S.B., Rona, P.A., and McGregor, B.A., 1974. The TAG Hydrothermal Field: Am. Geophys. Union Trans. (EOS), v. 55, p. 293.

Simkiss, K., 1964. Variation in the crystallization form of calcium carbonate from sea water: Nature, v. 201, p. 492493.

Tomasson, J. and Kristmannsdottir, H., 1972. High temperature alteration minerals and thermal brines, Reykjanes, Iceland: Contrib. Min. Petrol., v. 36, p. 123-134.

Topley, B. and Hume, J., 1928. The kinetics of the decomposition of calcium carbonate hexahydrate: Roy. Soc. London Proc., Ser. A, v. 120, p. 211-221.

Towe, K.M. and Malone, P.G., 1970. Precipitation of metastable carbonate phases from seawater: Nature, v. 226, p. 348-349. van Tassel, R., 1962. Carbonatniederschläge aus gemischten Calcium-Magnesiumchloridlösungen: Z. Anorg. Allgem. Chem., v. 319, p. 107-112.

Van Valkenburg, A., Mao, H.K., and Bell, P.M., 1971. Ikaite $\left(\mathrm{CaCO}_{3} \cdot 6 \mathrm{H}_{2} \mathrm{O}\right)$, a phase more stable than calcite and aragonite $\left(\mathrm{CaCO}_{3}\right)$ at high water pressure: Carnegie Inst. Washington Yearbook 70, 1970-1971, p. 237-238.

Velde, B., 1972. Celadonite mica: solid solution and stability: Contrib. Min. Petrol., v. 37, p. 235-247.

Winland, H.D., 1969. Stability of calcium carbonate polymorphs in warm, shallow seawater: J. Sediment. Petrol., v. 39 , p. $1579-1587$.

Yoder, H.S., Jr. and Tilley, C.E., 1962. Origin of basalt magmas: an experimental study of natural and synthetic rock systems: J. Petrol., v. 3, p. 342-532.

Zen, E., 1961. The zeolite facies: an interpretation: Am. J. Sci., v. 259, p. 401-409. 